\title{
Solomon Islands: Request for an Arrangement Under the Standby Credit Facility- Staff Report; Press Release on the Executive Board Discussion; and Statement by the Executive Director for Solomon Islands
}

In the context of request for an Arrangement under the Standby Credit Facility, the following documents have been released and are included in this package:

- The staff report for the Request for an Arrangement under the Standby Credit Facility, prepared by a staff team of the IMF, following discussions that ended on March 3, 2010, with the officials of Solomon Islands on economic developments and policies. Based on information available at the time of these discussions, the staff report was completed on May 21, 2010. The views expressed in the staff report are those of the staff team and do not necessarily reflect the views of the Executive Board of the IMF.

- $\quad$ A Press Release summarizing the views of the Executive Board as expressed during its June 2, 2010 discussion of the staff report that completed the request and/or review.

- $\quad$ A statement by the Executive Director for Solomon Islands.

The documents listed below have been or will be separately released.

Letter of Intent sent to the IMF by the authorities of the Solomon Islands*

Memorandum of Economic and Financial Policies by the authorities of the Solomon Islands*

Technical Memorandum of Understanding*

*Also included in the Staff Report.

The policy of publication of staff reports and other documents allows for the deletion of market-sensitive information.

\author{
Copies of this report are available to the public from \\ International Monetary Fund • Publication Services \\ $70019^{\text {th }}$ Street, N.W. • Washington, D.C. 20431 \\ Telephone: (202) 623-7430 • Telefax: (202) 623-7201 \\ E-mail: publications@imf.org Internet: http://www.imf.org
}

\section{International Monetary Fund Washington, D.C.}




\section{INTERNATIONAL MONETARY FUND}

\section{SOLOMON ISLANDS}

\section{Request for an Arrangement Under the Standby Credit Facility}

Prepared by the Asia and Pacific Department in Consultation with Other Departments Approved by Subir Lall and Dominique Desruelle

May 21, 2010

Background: The economy weakened in 2009, putting pressure on the government's depleted cash position and effectively necessitating a tightening of fiscal policy. The cash balance has fallen further in 2010, with national elections at mid-year bringing possible new pressures. Prospects are uncertain over the next few years in light of the challenging external environment and narrow production base, with external imbalances expected to remain large before gold exports resume in 2012. Without policy adjustment and donor support, the government's cash reserves would run dangerously low and an external financing gap averaging around US\$20 million a year would likely emerge in 2010-11.

Program: The authorities have requested a Fund arrangement to help promote fiscal and other reforms, reduce destabilizing imbalances, and close financing gaps, including by catalyzing additional donor support. Staff proposes an 18-month Standby Credit Facility (SCF) with access of 120 percent quota.

Mission: Staff teams visited Honiara on January 7-8, 2010 comprising Mr. Cowen (APD) and on February 17-March 3, 2010 comprising Messrs. Cowen (head), Botman, Feridhanusetyawan, and Zeng and Miss Seneviratne (all APD). Mr. Di Maio (OED) joined discussions during both missions.

Exchange rate regime: The Solomon Islands maintains an exchange system that is free of restrictions on payments and transfers for current international transactions. The exchange rate arrangement is currently classified as other managed arrangement.

Statistics: Data provision has some shortcomings, but is broadly adequate for surveillance. The authorities recognize the importance of improving the quality of macroeconomic data in order to better formulate policy and monitor outturns, with technical assistance particularly necessary in government finance statistics and national income accounts. 


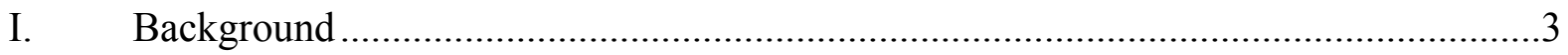

II. Recent Developments and Outlook ...................................................................

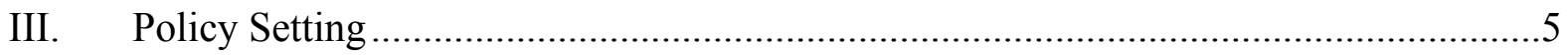

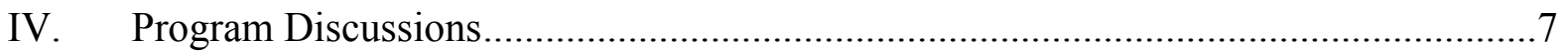

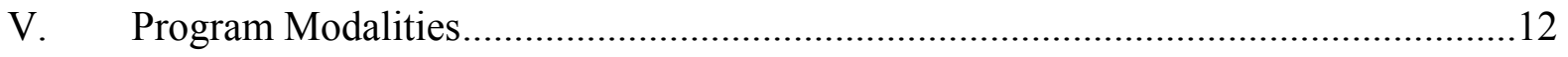

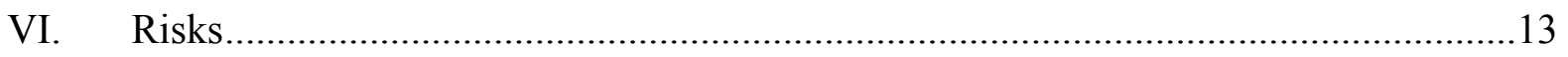

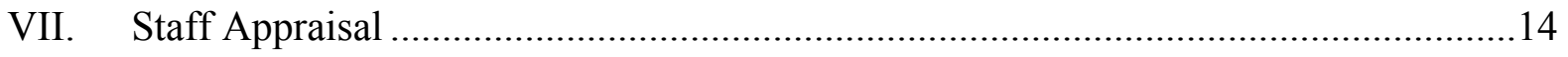

Box

1. Automatic Adjustment Mechanism for Log Prices ........................................... 9

Figures

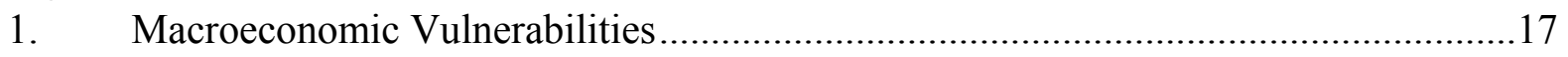

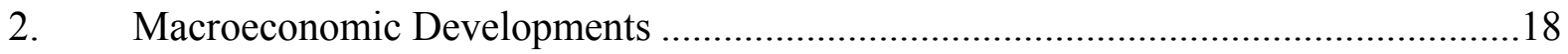

\section{Tables}

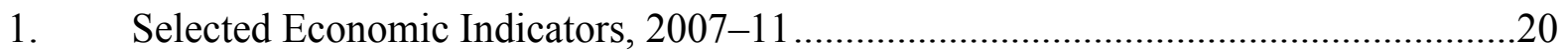

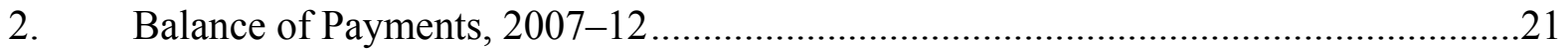

3. Summary of Fiscal Accounts, 2007-11 ….......................................................22

4. Summary Accounts of the Banking System, December 2008-December 2011 ........23

5. Medium-Term Baseline Scenario, 2008-15 .......................................................24

$6 \quad$ Reviews and Disbursement Under the Proposed Standby Credit Facility.................25

7. External Financing Requirements and Sources, 2009-12 .....................................26

8. Indicators of Capacity to Repay the Fund, 2009-19 ...........................................27

\section{Appendices}

I. Letter of Intent, Memorandum of Economic and Financial Policies, and Technical

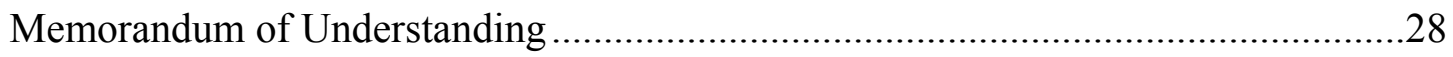

II. Debt Sustainability Analysis Update ........................................................... 46 


\section{BACKGROUND}

1. Over the past $\mathbf{1 8}$ months, the Solomon Islands has been adversely affected by fallout from the global recession and onset of a long-predicted decline in logging output. As a result, external and domestic pressures have increased macroeconomic vulnerabilities (Figure 1). Export growth turned negative in 2009 and domestic economic activity weakened. Nonetheless, reserves have strengthened due to declining imports and one-off factors, including the IMF's SDR allocations in August and September 2009. The government's policy response to the downturn has been limited. Fiscal policy has been constrained by the government's weak cash position and limited borrowing capacity. Monetary policy was eased largely through unsterilized foreign exchange market intervention. However, credit growth has yet to rebound, due to weak underlying conditions and heightened financial risks. Prospects are uncertain over the near term, with external imbalances expected to widen before gold exports resume in 2012. Without policy adjustment and donor support, an external financing gap averaging around US\$20 million a year would likely emerge. ${ }^{1}$

2. National elections will take place in mid-2010. The Parliament was dissolved on April 24, and all 50 seats of the unicameral legislature will be contested. The previous government continues to serve as a caretaker until a new post-election government is formed.

\section{RECENT DEVELOPMENTS AND OUTLOOK}

\section{Growth came under pressure in 2009, following several years of comparatively} strong performance. Based on official estimates, the economy contracted by $2 \frac{1}{4}$ percent in 2009, compared with an expansion of 71/4 percent in 2008 (Figure 2 and Table 1). The fall in activity was mainly due to declining production of fish and timber (the latter down nearly 30 percent) and weak commodity prices and output (notably copra), which fed into domestic demand. Inflation pressures eased mostly due to falling fuel and food prices, with the headline rate at 1.8 percent (y/y) in December 2009, compared to 18.1 percent a year earlier. The overall external position improved in 2009. The current account deficit widened to 21 percent of GDP, largely owing to lower logging exports and higher repatriated profits, including by foreign bank subsidiaries (Table 2). On the other hand, the capital and financial accounts were boosted by increases in mining-related foreign direct investment (FDI), reinvested earnings, and other private and official inflows, including the SDR allocations. As a result, gross official reserves were US\$146 million at end-2009 (41/4 months of next year's imports of goods and nonfactor services), compared to US\$90 million (31/2 months of import cover) at end-2008.

\footnotetext{
${ }^{1}$ The projected external financing gap is based on the assumption of maintaining a foreign reserves cover of at least five months of next year's imports of goods and nonfactor services. This degree of coverage takes into account historical levels of reserves, their recent volatility, and the narrowness of the export base.
} 
4. The near-term macroeconomic outlook is expected to remain challenging. Growth is projected to rebound to around $3 \frac{1}{2}$ percent in 2010 on a global recovery in commodity demand and prices and new investment and capacity improvements in mining, telecommunications, and fisheries. Inflation is expected to rise moderately on higher fuel and food prices and waning base effects. The current account deficit is projected to widen further to 30 percent of GDP in 2010, but narrow slightly in 2011, as demand for imports associated with new FDI moderates. Gross reserves are expected to rise to US $\$ 168$ million (43/4 months of imports) by end-2010 and further to US $\$ 187$ million ( $5 \frac{1}{4}$ months of imports) by end 2011. Under this scenario, exceptional support would come principally from the IMF and the European Union (EU). The EU has tentatively agreed to a budget support operation under its crisis-related Vulnerability-Flex (V-FLEX) Instrument of around $€ 15$ million, subject to a Fundsupported program. A single disbursement is expected in the fourth quarter of 2010. Additional EU budget support of $€ 4$ million is expected in $2011 .^{2}$ Without this support, reserves would fall to around US\$137 million at end 2010, or equivalent to 4 months of imports-below the historical cover and exposing the Solomon Islands to greater vulnerability.

\begin{tabular}{|c|c|c|}
\hline \multicolumn{3}{|c|}{$\begin{array}{l}\text { Solomon Islands: Budget Support and } \\
\text { Exceptional Financing, 2010-11 } \\
\text { (In millions of U.S. dollars) }\end{array}$} \\
\hline & 2010 & 2011 \\
\hline \multicolumn{3}{|l|}{ Budget support } \\
\hline Asian Development Bank & 5 & 5 \\
\hline Australia & 10 & 11 \\
\hline New Zealand & 7 & 7 \\
\hline Taiwan Province of China & 11 & 10 \\
\hline Total & 32 & 32 \\
\hline \multicolumn{3}{|l|}{ Exceptional financing } \\
\hline European Union (budget support) 1/ & 21 & 6 \\
\hline IMF (prospective arrangement) & 10 & 10 \\
\hline Total & 31 & 15 \\
\hline \multicolumn{3}{|c|}{$\begin{array}{l}\text { Sources: Solomon Islands authorities; and IMF staff } \\
\text { estimates and projections. }\end{array}$} \\
\hline \multicolumn{3}{|c|}{$\begin{array}{l}\text { 1/ For } 2010 \text {, under the V-Flex Instrument; for } 2011 \text {, } \\
\text { other budget support. }\end{array}$} \\
\hline
\end{tabular}

\section{Over the medium term, growth and export prospects are expected to be guided by} agriculture and fishery, tourism, and resource sectors, notably mining. With gold production expected to come on stream in 2012, GDP growth should pick up significantly starting then. ${ }^{3}$ Led by rising mineral exports (more than offsetting declining logging exports) and reinforced by stable macroeconomic conditions, the external financing gap is expected to close. Nonetheless, current account deficits are projected to remain large into mid-decade principally due to a sizable import requirement of prospective nickel mining operations, mainly FDI financed (Table 5). ${ }^{4}$

\footnotetext{
2 The Asian Development Bank approved a two-year budget support operation of US\$10 million (SI\$80 million) in March 2010, with US\$5 million already built into this year's budget.

${ }^{3}$ The previously shuttered GoldRidge mine is expected to reopen in 2012 and produce around 100,000 ounces of gold annually.

${ }^{4}$ A few mining companies are in the exploratory phase for possible nickel deposits. An international tender is planned for several concessions in 2010, with nickel production expected to commence in 2014.
} 


\section{Policy Setting}

\section{Fiscal policy}

6. Fiscal discipline has not been sufficiently strong in recent years, with the economic downturn in 2009 putting further pressure on the government's core cash position.

Despite improvements in tax and customs administration, growth in revenues has not kept pace with that of expenditures, also taking into account debt repayment costs. Adding to pressure is falling logging-related revenue, because of declining production and lower effective taxation. With little capacity to borrow at home or abroad, even moderate budget pressures have eroded cash balances and led to periodic shortages. In 2009, these shortages were met by delaying payments to creditors and through across-the-board spending reservations-both permanent and temporary - affecting the government's ability to fund priority areas, including social and development outlays. Capacity within line ministries and agencies to formulate and execute budget plans is constrained by the lack of operational and financial resources, integrated budget and cash management systems, and a credible fiscal strategy. Supplemental appropriations have undermined budget discipline. Data on fiscal outturns are also incomplete, as a large portion of development expenditure is administered outside the official budget and not systematically reported, including funds from the Regional Assistance Mission to Solomon Islands (RAMSI) and other donors.

\section{The preliminary fiscal outturn for 2009 indicates an overall fiscal surplus} equivalent to $2 \frac{1}{4}$ percent of GDP, but this masks underlying pressures (Figure 2 and Table 3). Revenue fell slightly as a share of GDP, mainly because of lower logging export duties and petroleum-related taxes. Partially offsetting these losses were further administrative gains in revenue collection and excise and import duty increases on select luxury items at midyear. Expenditure was restrained, following a sharp rise in 2008, with a 10 percent permanent reservation imposed at mid-year (on most nonwage recurrent spending), a civil service hiring freeze, and large locally-financed development spending cuts, against the original budget. Nonetheless, the gross cash balance still declined by SI\$31 million ( 0.6 percent of GDP). ${ }^{5}$ By year end, the government's gross cash position was around SI\$106 million (3-4 weeks of forward recurrent spending), but on a net basis (including unpaid payment orders and unpresented checks) stood at less than SI\$50 million. ${ }^{6}$

\footnotetext{
${ }^{5}$ The gross cash balance captures the core government deposits readily available for fiscal financing. However, it exclude other government deposits, which mainly comprise select accounts related to donor funding and, since late 2009, a holding account for the receipts from sale of a second telecommunications license (SI\$31 million). Funds in the latter are expected to be paid out to OurTelekom, the original telecommunications licensee, in 2010 as compensation for the loss of its monopoly.

${ }^{6}$ In the Solomon Islands, no formal definition of domestic arrears exists. The net cash balance, however, encapsulates the concept by accounting for the two principal and measurable means by which the government defers domestic payments (i.e., unpaid payment orders and unpresented checks).
} 


\section{Monetary, exchange rate, and financial sector policies}

8. Monetary conditions have eased considerably, mainly due to foreign inflows. Since mid-2009, the Central Bank of Solomon Islands (CBSI) has purchased significant amounts of foreign exchange from banks, in part due to relatively weak import demand and limits on banks' overnight balances. Under these conditions, the exchange rate has stayed virtually unchanged vis-à-vis the U.S. dollar. On the other hand, the real effective exchange rate depreciated by about 10 percent (for the year ending February 2010), largely due to U.S. dollar weakness against trading partner currencies. Banks, in turn, have accumulated sizable excess reserves, with reserve money growing by 54 percent (y/y) in 2009 (Table 4). Despite looser conditions, lending rates remain sticky in nominal terms (but have risen considerably in real terms), likely because of banks' greater risk aversion and residual inflation concerns. Given these factors and the weak economy, private sector credit declined by 4 percent. ${ }^{7}$ To better manage short-term liquidity conditions, the CBSI continues to refine its liquidity forecasting framework, introduced in mid-2009. It plans to strengthen operational capacity by refining standing facilities around a benchmark rate and developing other instruments over the near to medium term.

\section{Given the downturn, risks facing banks appear on the rise, despite their recent}

financial performance. In response, the CBSI has introduced new prudential guidelines on capital adequacy, loan loss recognition, and large credit exposure since the start of the global crisis to help safeguard the banking system. However, full compliance with these new guidelines is incomplete. Nonperforming loans (NPLs) have increased recently but are still moderate (the rise in 2008 is partly due to changes in loan-loss recognition). Net interest margins remain large and banking fees high.

\begin{tabular}{|c|c|c|c|c|}
\hline \multicolumn{5}{|c|}{ Solomon Islands: Core Financial Soundness Indicators 1/ } \\
\hline & 2006 & 2007 & 2008 & 2009 \\
\hline & \multicolumn{4}{|c|}{ (In percent) } \\
\hline \multicolumn{5}{|l|}{ Capital adequacy: } \\
\hline Regulated capital to risk-weighted assets & 21.8 & 17.9 & 22.6 & 22.0 \\
\hline Tier 1 capital to risk-weighted assets & 17.3 & 14.2 & 18.3 & 15.6 \\
\hline Nonperforming loans, net of provisions to capital & 0.8 & 2.0 & 7.9 & 10.3 \\
\hline \multicolumn{5}{|l|}{ Asset quality: } \\
\hline Nonperforming loans to total gross loans & 0.5 & 0.8 & 2.7 & 3.8 \\
\hline \multicolumn{5}{|l|}{ Earnings and profitability: } \\
\hline Return on average assets $2 /$ & 7.4 & 8.4 & 10.4 & 8.1 \\
\hline Return on average equity $2 /$ & 49.5 & 63.6 & 68.6 & 56.8 \\
\hline Interest margin to gross income & 47.2 & 47.3 & 50.2 & 47.2 \\
\hline Noninterest expenses to gross income & 44.1 & 41.2 & 34.3 & 43.5 \\
\hline \multicolumn{5}{|l|}{ Liquidity: } \\
\hline Liquid assets to total assets (liquid asset ratio) & 24.8 & 16.3 & 10.3 & 20.5 \\
\hline Liquid assets to short-term liabilities & 54.0 & 34.4 & 28.3 & 55.5 \\
\hline
\end{tabular}
Despite lower investment income, the National Provident Fund (NPF) - the country's largest nonbank institution, bank depositor, and savings vehicle - generated an operating surplus in its latest fiscal year (ending June 30, 2009), as interest credited to members also declined.

\footnotetext{
${ }^{7}$ Contributing to the decline was repayment of a large private loan in mid-2009 at one commercial bank through offshore borrowing. As a result, the bank was able to meet its liquid asset requirement. It also sold a sizable amount of foreign exchange received from the loan repayment to the CBSI, boosting official reserves.
} 


\section{Program Discussions}

10. The authorities' program seeks to strengthen public finances and reduce destabilizing imbalances, building on current reform plans, including those elaborated in the government's Economic and Financial Reform Priorities. It seeks to catalyze additional donor support to fill projected financing gaps. The authorities see these gaps as largely transitory, given medium-term prospects for mining, fishing, and other commodity-related exports, and therefore prefer a shorter-term arrangement. In addition to gold, the Solomon Islands has potentially large yet unproven reserves of nickel, which it seeks to begin mining by mid-decade. The authorities agree that sound development of the mining and other resourcerelated activities requires an appropriate tax and regulatory regime, which they seek to strengthen in the next few years, in collaboration with development partners. Under these circumstances and with relatively low indebtedness, the authorities believe they will have sufficient resources to meet the Solomon Islands' financing requirements and to repay the Fund.

\section{Fiscal policy}

\section{Efforts are needed to put the Solomon Islands on a sustainable fiscal path and} reduce its vulnerability to external shocks, by broadening the tax base, strengthening revenue administration and cash and debt management, and prioritizing spending outlays. Since 2005, ongoing debt restructuring and limits on borrowing have helped avert a crisis, following a sharp deterioration in public finances and weakening of the external position early in the last decade. ${ }^{8}$ However, structural fiscal problems persist that undermine sound budget management and performance.

12. Cash build up: To normalize fiscal operations and improve budget execution, the authorities are committed to building up cash reserves in 2010 and 2011. To achieve this, an overall budget surplus of $2 \frac{1}{2}$ percent of GDP is targeted in 2010, representing a modest yet necessary tightening against a gradual economic recovery. The cash balance would increase on a net basis by SI $\$ 120$ million to around SI\$170 million by year-end. To achieve this target, the authorities have taken up-front measures (discussed below) and will expedite other reforms already in train. Also underpinning this adjustment is the new exceptional financing from the EU.

13. Revenue measures: The authorities recognize concentrated efforts are needed to further strengthen revenue policy, improve tax administration and compliance, and broaden the tax base. Given the fragile economy and already sizable burden on existing taxpayers, the

\footnotetext{
${ }^{8}$ External borrowing has been restricted since 2005 under the terms of the Honiara Club Agreement (HCA), which was signed by the government and four major external creditors. Under the agreement, the Solomon Islands is expected to pursue grants and other overseas development assistance until it receives "green light" status from the World Bank's International Development Association, which is comparable to low risk of debt distress under the IMF-World Bank Debt Sustainability Analysis (DSA) framework.
} 
authorities preferred focusing on administrative efforts to increase tax revenues, which they argued had delivered sizable revenue gains in recent years. Under the program, revenue targets are based on several up-front measures:

- $\quad$ Strengthening of customs enforcement and improvement of post-clearance audits, focused on alcoholic beverages and personal and luxury vehicles, on which new excises and import duties have been applied. In support of these efforts, a special customs cargo inspection task force was reintroduced in May 2010, with a Customs Deputy Controller focusing on this area to be appointed later this year (MEFP 98 ).

- $\quad$ Adjustment from April 1, 2010 of the determined price of logs (DPLs) used for taxation purposes from US\$77 to US\$83 per cubic meter, taking account of recent deviations between world prices and the determined values (Box 1);

- $\quad$ Adoption by end-September 2010 of an automatic adjustment mechanism for the DPLs in order to align the taxable price more closely with world market prices and improve overall transparency surrounding the use of this vital yet exhaustive natural resource (a program benchmark) (MEFP \8). Based on the mechanism, the authorities have agreed to increase the determined values to no less than 85 percent of the formula-based price from October 1, 2010, with a quarterly phase-in of 5 percentage points thereafter to achieve the full formula-based price from July 1, 2011.

In total, these measures are expected to yield SI\$24 million in revenue in 2010 ( 0.4 percent of GDP). In addition, as part of the program, the authorities will:

- $\quad$ Apply successively stronger enforcement actions to collect tax and customs-related arrears, including, where appropriate, by suspending import licenses and by seizing bank deposits of delinquent taxpayers (a continuous program benchmark) (MEFP 98 ). Further revenue gains are expected to accrue in the areas of taxpayer registration and audits.

- Tighten the use of exemptions, through issuance of a ministerial circular by June 2010 authorizing annual notification to the Public Accounts Committee of the nature and cost of all tax and customs exemptions granted (a program benchmark) (MEFP 99); and submit to Parliament by December 2010 of a set of amendments to the Customs and Excise and Income Tax Acts legalizing exemption criteria and guidelines, including full disclosure requirements, and merging existing exemption committees into a unified committee structure (a program benchmark) (MEFP 99 ).

- Amend the Customs Valuation Act and issue new implementation guidelines by end2010, bringing the act into full effect by December 2010 (a program benchmark) (MEFP 99). The new act, which aims to ensure consistency with World Trade Organization valuation methods, was approved in 2009 but has not been implemented due to legal ambiguities defining the transaction value of imported goods, which will be corrected through the amended act. 


\section{Box 1. Solomon Islands-Automatic Adjustment Mechanism for Log Prices}

The Solomon Islands has foregone considerable fiscal revenues from logging exports in recent years. The problem stems from a lack of proper invoicing and controls needed to collect export duties and timber royalties. The government has been reluctant to press collections of these revenues, given the powerful political sway exercised by loggers (including foreign interests). As a result, sizeable economic rents have been captured by timber producers and logging exporters.

To rectify this problem, the authorities adopted a mechanism in $\mathbf{2 0 0 7}$ for deriving a schedule of log prices used to collect revenues by species and grade. Under the mechanism, the weighted-average determined price of logs (DPLs) is expected to be aligned with the estimated FOB price of round logs as follows:

- $\quad$ The estimated FOB price $=$ average CIF price of round logs less freight and insurance costs and agents' fees.

- The average CIF price refers to the selling price of Solomon Islands' logs in its major markets (mainly China, Japan, and Korea).

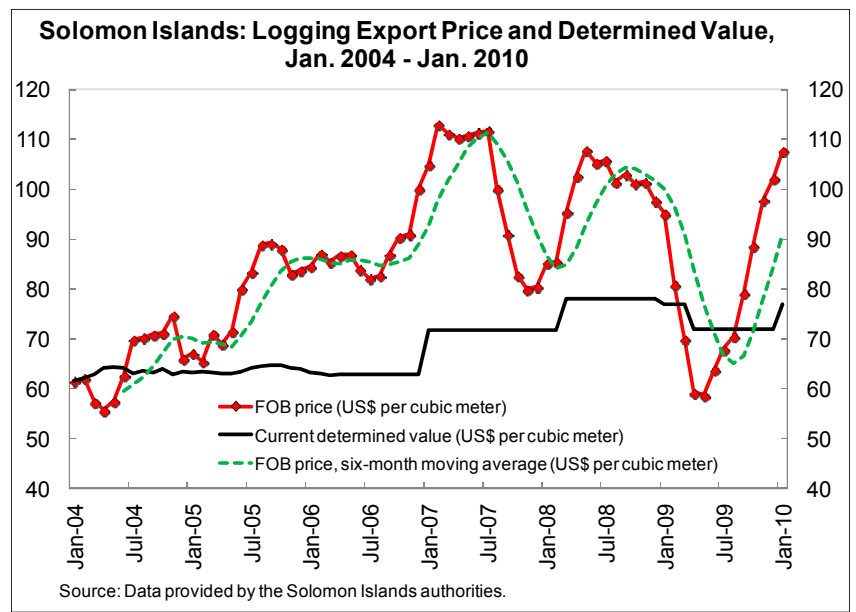
Published information is used on these 'landed' prices (including freight and insurance costs) from the Global Trade Atlas and on freight costs from the International Tropical Timber Organization. Insurance costs and agents' fees are estimated at 2 and 6 percent of the market value, respectively.

- As originally envisaged, the estimated FOB price would be updated quarterly and used to derive the DPL schedule. For this purpose, the Ministry of Finance and Treasury (MoFT), which prepares the schedule, collects Customs data on the actual species and grades of logs exported. Higher-grade species are valued more than lower-grade species. In the event of full adjustment, the weighted average determined price would equal the estimated FOB price calculated from the formula above.

However, the estimated FOB price of round logs, as the benchmark for deriving the DPLs, is almost always higher than the weighted-average determined value. This difference is mainly due to discretion exercised by the MoFT in updating and adjusting the DPLs to reflect the true price of logs sold. As a result, it has created uncertainty among exporters about taxable prices, possibly causing shipment delays and encouraging tax evasion.

Under the program, the authorities will adopt an automatic adjustment mechanism and update the DPL schedule on quarterly basis from October 1, 2010, phasing in full adjustment by July 1, 2011. Once the automatic adjustment mechanism is fully adopted, the MoFT is expected to retain the authority to set the weighted-average DPL within $\pm 2 \frac{1}{2}$ percent of the formula-based price. To facilitate implementation of the new valuation method by Customs officials, the schedule of prices would be rounded to the nearest Solomon Islands dollar. 
- $\quad$ Formulate a tax regime by June 2011 to better capture economic rents from the burgeoning natural resource sector, notably in mining, consistent with envisaged technical assistance from the Fund and ongoing work on mining policy with the World Bank (a program benchmark) (MEFP $\$ 12$ ). The authorities are also giving consideration to subscribing to the Extractive Industries Transparency Initiative.

14. Expenditure measures: The authorities recognize that weak budget discipline and expenditure restraint have been major contributors to the cash drawdown in recent years. The absence of proper cash, accounting, and auditing controls has limited proper oversight, although measurable progress in each of these areas is beginning to take shape. The authorities have developed a rolling three-month forward cash forecast for the government's recurrent and development budget, which they plan to extend forward and integrate with cash and debt management, with ongoing technical assistance from the World Bank (a prior action) (MEFP 911). Moving toward a Treasury single account framework is another medium-term objective in strengthening cash controls. To alleviate current pressures, other up-front measures are as follows:

- Issuance of a ministerial circular in March 2010 indicating contingency warrants in 2010 must be fully funded by line-item adjustments to ministerial appropriations or additional revenue measures, in order to safeguard the cash position in the event of additional spending pressures (a prior action) (MEFP $₫ 8$ ).

- Withdrawal of annual spending warrants in May 2010 yielding net savings of at least SI\$116 million (2 percent of GDP) (a prior action) (MEFP $\mid 8$ ). In addition, the government has temporarily withdrawn other spending warrants to conserve cash. These moves still protect priority spending - especially that funded through education and health-related budget support.

In the context of the program, the authorities also will:

- Incorporate all line ministries and establishment positions in the civil service into a new payroll accounting system by December 2010 (a program benchmark) (MEFP q8). The authorities also intend to cap the government wage bill at SI\$515 million (91/4 percent of GDP), slightly larger than budgeted after factoring in donor-supported commitments to hire new health and education workers in 2010.

- $\quad$ Adopt a budgetary framework that guarantees sound fiscal management for this and future governments. As a centerpiece, the authorities will draft a fiscal responsibility act or place relevant provisions in an amended Public Finance and Audit Act by June 2011 (a program benchmark) (MEFP \12) .

15. Other structural fiscal reforms: The program will look for broader progress in strengthening public financial management (PFM). As noted, considerable work is already under way with other donors' technical support (including RAMSI) in this area. The authorities 
also envisage working with the World Bank on a Public Expenditure Review later this year. This exercise is expected to guide reforms aimed at reprioritizing budget allocations and improving budget outcomes. The authorities are also developing a better expenditure tracking system to monitor and safeguard social and other priority spending. Over the medium term, development spending is expected to decline (as a share of GDP), in line with a scaling back of project grants currently funding technical and security support. In this regard, better execution and targeting of the government's own development budget will also require that budget allocations be aligned with spending priorities, notably those set forth in the planned update of the Medium-Term Development Strategy in 2010, with lead assistance expected from the Asian Development Bank. In addition, greater control over parliamentary entitlements will ensure more resources in priority areas. Progress is expected in strengthening the operational and financial performance of state-owned enterprises, notably the power and water authorities, with donor technical support. These efforts are aimed at regularizing collections, settling crossdebts, and achieving cost recovery, curtailing the need for government funds and ultimately containing fiscal risks.

\section{Monetary, exchange rate, and financial sector policies}

16. Monetary policy: In view of the near-term outlook, the authorities will pursue a moderately accommodative monetary policy, while monitoring inflation developments closely and being prepared to tighten policy, as necessary. Given the sizable amount of excess reserves at the CBSI, banks could unleash a large amount of new lending. However, in view of nearterm prospects, credit growth is expected to be around 12 percent (y/y) in 2010. With the Solomon Islands dollar effectively pegged to the U.S. dollar, fiscal policy will continue to anchor macroeconomic stability. In this regard, program targets on net credit to the government and net domestic assets of the CBSI are appropriately restrained.

17. Operational framework: Building on recent progress, further steps will be taken under the program to strengthen the CBSI's operational framework and introduce new instruments for conducting monetary policy. Over the program period, the authorities plan to replace the current liquid asset requirement with a required reserve system, introduce new overnight facilities, and, by December 2010, finalize an issuance plan for shorter maturity CBSI bills, if necessary with further IMF technical assistance (a program benchmark) (MEFP -15). They are also committed to strengthening lender of last resort provisions through new central bank executive regulations by June 2010 (a program benchmark) (MEFP $\mid 15$ ).

18. Exchange rate policy and foreign reserves: The authorities agree to take necessary actions to maintain an adequate level of foreign reserves, in light of the Solomon Islands' vulnerability to shocks. Currently, the exchange rate serves as a useful nominal anchor given high pass-through of international fuel and food prices, the narrow domestic production base, and limited monetary controls. However, the authorities agreed greater flexibility may be necessary to achieve the program's net international reserves targets by allowing larger day-today movements in the interbank exchange rate. As noted in the 2009 Article IV consultation staff report, addressing external vulnerabilities also requires broader measures to improve 
competitiveness, in particular better infrastructure, more business friendly regulation, and an equitable tax regime.

19. Financial sector: The authorities are committed to tightly enforcing new prudential guidelines and to further improving both on-site and off-site monitoring and supervision of banks. With technical assistance, the CBSI plans to extend new prudential and reporting requirements to nonbank financial institutions. It also will begin publishing financial soundness indicators. With regard to the NPF, the authorities are committed to better protect the independence of its operations. Under the program, they plan to submit a revised NPF Act to Cabinet by December 2010 clarifying the CBSI's supervisory responsibilities, the provident fund's investment mandate, and its obligations to member contributors to safeguard long-term

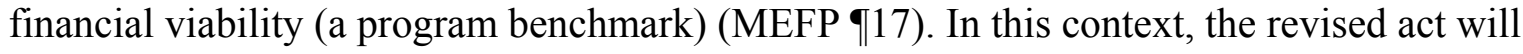
clarify the social role envisaged for the NPF to ensure it does not undermine the sound management of its assets and generation of a fair return for contributors.

\section{Program Modalities}

20. Access: Given recently volatile reserves and the uncertain external environment, resources need to be made available to ensure the central bank can adequately mitigate the effects of shocks in this transition period. For this reason, the authorities have requested a SCF with a normal access of 120 percent quota (SDR 12.48 million) with equal semi-annual disbursements over an 18-month period (Table 6). ${ }^{9}$ This access level is based on the projected external financing gap (averaging US\$20 million a year during 2010-11), strength of the program, and, as discussed below, capacity to repay

21. Financing: The government is expected to receive additional budget support in the form of grants - the largest through the EU's V-FLEX Instrument - to meet its budgetary financing needs during 2010-11. With these resources and the prospective Fund arrangement, balance of payments financing needs should be met, also allowing the maintenance of sufficient reserves coverage (Table 7).

22. Conditionality and reviews: Conditionality is intended to be parsimonious and focused on macro-critical areas, namely by building a cash buffer to normalize fiscal operations, improving monetary operations, and strengthening of financial sector oversight. Given up-front risks to the program and with national elections on the horizon, prior actions are significant. Strong performance under the authorities' program could signal to future creditors that the Solomon Islands can undertake regular concessional borrowing in the medium term. The program will be monitored through semi-annual reviews, quantitative conditions, and structural benchmarks (MEFP Tables 1 and 2).

\footnotetext{
${ }^{9}$ Based on the World Bank's Atlas method, the Solomon Islands' per capita gross national income for 2008 is estimated at US $\$ 1,050$, which is below the IDA operational cut-off for FY2010 of US\$1,135. Therefore, a fully concessional (i.e., nonblended) arrangement is proposed.
} 
23. Capacity to repay: The authorities' commitment to implement their program and the favorable prospects for mineral and other commodity exports provide reasonable assurances of the capacity to repay the Fund. If purchases are made as scheduled, the repurchases peak in 2015-17 and are completed by 2020. Annual repayments to the Fund would amount to less than 1 percent of exports of goods and services or $1 \frac{1}{2}$ percent of GDP (Table 8 ).

24. Debt sustainability analysis: Public debt has fallen significantly in recent years, and the impact of the prospective Fund-supported arrangement is expected to be minimal, with the Solomon Islands remaining at a medium risk of debt distress (Appendix II). ${ }^{10}$

25. Arrears: All external arrears to private creditors have been cleared. An agreement was reached in 2009 with the European Investment Bank to resolve the remaining outstanding arrears of about US\$3 million, which are expected to be cleared this year.

26. Safeguards: A safeguards assessment of the CBSI is expected to be completed by the envisaged first review of the Fund-supported program, with work already under way.

\section{RISKS}

27. The program is subject to considerable risks stemming from policy uncertainty, capacity constraints, and possible weak ownership. Some risk mitigation has occurred by implementing prior actions. With the previous government continuing as a caretaker ahead of national elections, current policies are well aligned with program understandings. However, limited policy and technical capacity may hamper program implementation and monitoring. The relatively short length of the envisaged program places added pressure. With virtually no past program engagement with the Fund, local ownership in design, implementation, and monitoring of the program is critical to ensure its success. Complementing these efforts is a timely transfer of knowledge and skills by external policy and technical advisors, notably under the RAMSI umbrella, to local officials charged with the task of macroeconomic management. Other risks could arise as follows:

- $\quad$ Fiscal: Budget pressures could emerge leading up to or after the elections, including from the expected issuance of a supplementary budget at mid-year, possibly affecting program targets. Under a reasonably cautious outlook, the cash situation is still expected to remain tight until late 2010. Even if targets are met, spending could be skewed toward low priority activities at the cost of critical outlays. Major PFM reforms aimed at strengthening fiscal discipline, in particular the adoption of integrated budget, government accounting, and Treasury single account frameworks, could take some time, given capacity constraints. The new government could also adopt policies inconsistent with program objectives. However, the first review is timed sufficiently early in the program to undertake corrective measures, as needed, to ensure the main program objectives are met.

\footnotetext{
${ }^{10}$ In line with HCA, the limit on nonconcessional borrowing is set at zero continuously over the program period.
} 
- Monetary: The excess liquidity that has built up in the banking system since mid-2009 could give way to a more rapid credit expansion than currently programmed. Adding to possible inflation pressures could be an associated pickup in the demand for foreign exchange, putting downward pressure on the exchange rate and requiring further possible tightening, with limited instruments to do such quickly outside foreign exchange intervention, putting possible pressure on foreign reserves.

- $\quad$ Financial sector: A weaker than expected recovery could expose banks to a further rise in NPLs, necessitating additional loan-loss provisions and write-downs, impinging bank profitability and stymieing future loan growth. As for the NPF, the formal lack of independence risks undue interference in asset management, potentially compromising the long-term viability of the provident fund.

- Macroeconomic outlook: The baseline outlook under the program is subject to substantial downside risks. With growth likely concentrated in a few sectors in 2010, risks could arise from delays in large FDI projects, dampened global demand for commodities, or adverse moves in commodity prices. Timber production could also decline more than envisaged, given recent trends. Unanticipated increases in fuel and food prices could put further pressure on inflation and exchange rates and the external position. Budget lapses and reform delays could add to this strain by undermining donor and investor confidence, reducing external inflows, and deferring growth and competitiveness gains. The medium-term outlook — on the growth, fiscal, and external fronts - is also highly dependent on timely start-up of new mining operations, which face potential land, power, and financing issues.

\section{Staff APPRAisal}

28. Overview: The effects of the global recession and decline in logging have undermined macroeconomic stability in the Solomon Islands. The economy continues to be susceptible to adverse shocks. In the absence of policy adjustment and exceptional donor and Fund support and given limited recourse to borrowing, the government could exhaust cash reserves soon and incur new arrears. This pro-cyclical policy response could put the economic recovery further out of reach and magnify other risks. With current account deficits already projected to be large over the medium term, the stock of foreign exchange reserves could decline rapidly and the pressures on exchange rate could reemerge in the face of a negative terms of trade shock or excessive loosening in fiscal policy. To reduce these imbalances and close projected financing gaps, the government will need to adhere closely to program commitments to bring lasting adjustment. The resumption of gold production in 2012 is expected to improve growth and export prospects. However, more equitable growth and poverty alleviation efforts will require stable macroeconomic conditions, wide-ranging structural reforms, and broader social and infrastructure development. All of this will be essential to improving the business and investment climate and ultimately ensuring new labor-intensive productive opportunities. To these ends, the government must build its technical and managerial capacity, enhance private sector activity, and use donor resources more effectively. 
29. Program: The authorities' program offers a basis for resuming strong growth in a low inflation environment, helping to advance poverty alleviation efforts and achieve other development objectives. Its core elements are to strengthen government finances, improve monetary operations, safeguard international reserves, and contain financial sector risks. All prior actions have been taken and other program conditionality is focused on macro- critical areas to better ensure lasting adjustment. A number of critical technical assistance and capacity building requirements have been identified, to be met by the Fund and other development partners.

30. Fiscal policy: The focus of the program foremost lies in the fiscal area. Against several years of lax fiscal policies, key priorities must be to reconstitute cash reserves, fully fund social and development outlays, and build budget credibility with key stakeholders. Based on program commitments and working closely with development partners, the authorities have a credible strategy for strengthening fiscal operations centered on better revenue administration, budget, cash, and debt management, and expenditure prioritization. Adopting a fiscal responsibility law, devising a proper resource tax regime - including for logging, and accelerating work on medium-term PFM reforms will help strengthen policy discipline and transparency and ensure the Solomon Islands remains on a sustainable fiscal path. All will be critical to demonstrating to current and prospective donors and creditors the soundness of fiscal operations and the government's ability to undertake regular borrowing.

31. Monetary and exchange policy: The current monetary policy stance is broadly appropriate, with monetary targets sufficiently accommodative to support economic recovery. Efforts envisaged under the program to strengthen the operational framework and introduce new policy instruments will be important to better assist banks in managing liquidity and ensure long-term price stability. While foreign reserves have grown significantly since mid2009, the downside to this reduction in external vulnerability is a possible liquidity overhang. The CBSI will need to monitor this situation closely and be prepared to exit its accommodative stance, including through allowing greater exchange rate flexibility.

32. Financial sector policy: The CBSI has taken sound steps recently to help stem heightened risks facing the banking sector. Given rapid credit expansion in recent years and now weak domestic activity, asset quality could further deteriorate over the near term. Thus, timely and consistent enforcement of new prudential guidelines will be critical to keeping NPLs low and ensuring banks maintain an adequate capital base to support economic recovery. By strengthening the oversight and independence of the NPF, the authorities can better ensure the provident fund will have an adequate liquidity buffer and generate a sufficient risk-adjusted return as necessary to safeguarding member contributions and ensuring its long-term financial viability.

\section{The authorities' program, while not without risk, is well focused and sufficiently} ambitious to merit Fund support. Without this and other donor support, the Solomon Islands may not be able to avoid severe fiscal and balance of payments pressures. Notwithstanding the dissolution of the Parliament, the previous government continues to serve as a caretaker, 
providing assurances that the program can be implemented as designed. Therefore, staff recommends the approval of the request for a Standby Credit Facility Arrangement.

34. It is expected that the next Article IV Consultation with the Solomon Islands be held in accordance with Decision No. 12794-(02/76), as amended. 
Figure 1. Solomon Islands: Macroeconomic Vulnerabilities

Growth, exports, and fiscal revenues have been adversely affected by the decline in logging production, which is expected to drop further in upcoming years until depletion around 2015-17.

\section{Logging Exports and Tax Revenue, 2002-09}

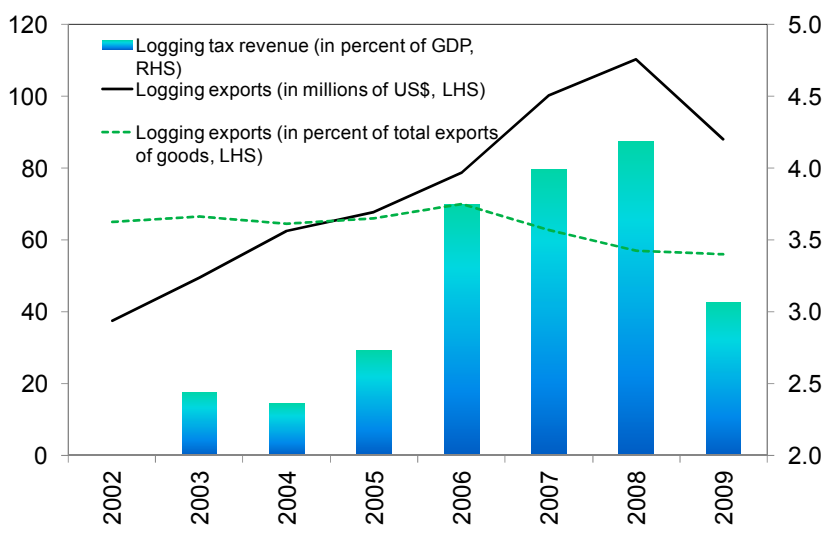

Increases in the price of food and fuel, two major imports, have been principally responsible for the deterioration of its terms of trade in recent years...

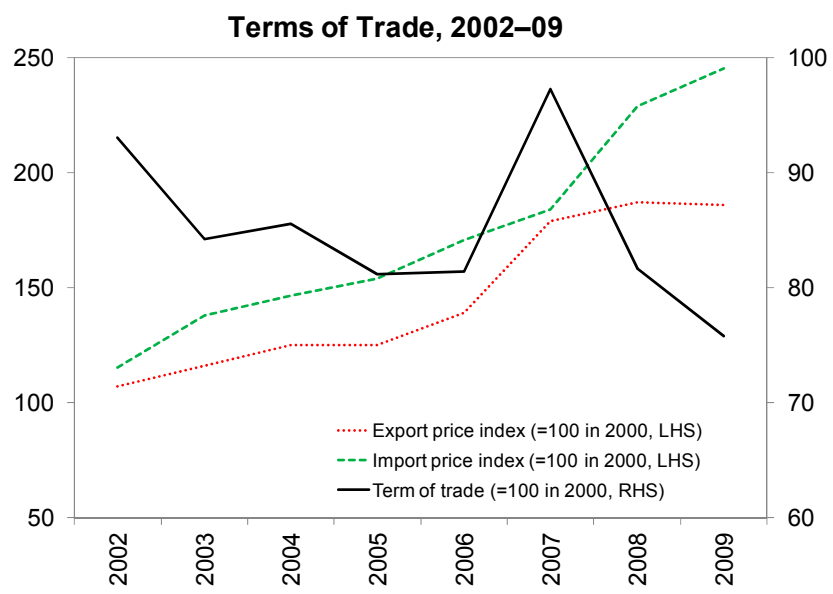

The loss of logging-related revenues, combined with other factors, has caused a rundown in government cash balances, straining normal fiscal operations.

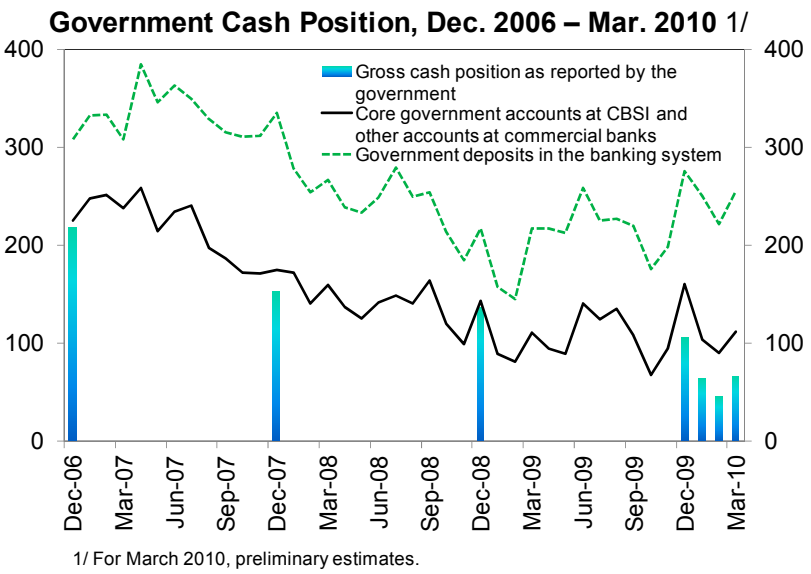

...contributing to the sharp decline in international reserves during the global economic crisis, with the recent resurgence not reflective of any underlying adjustments.

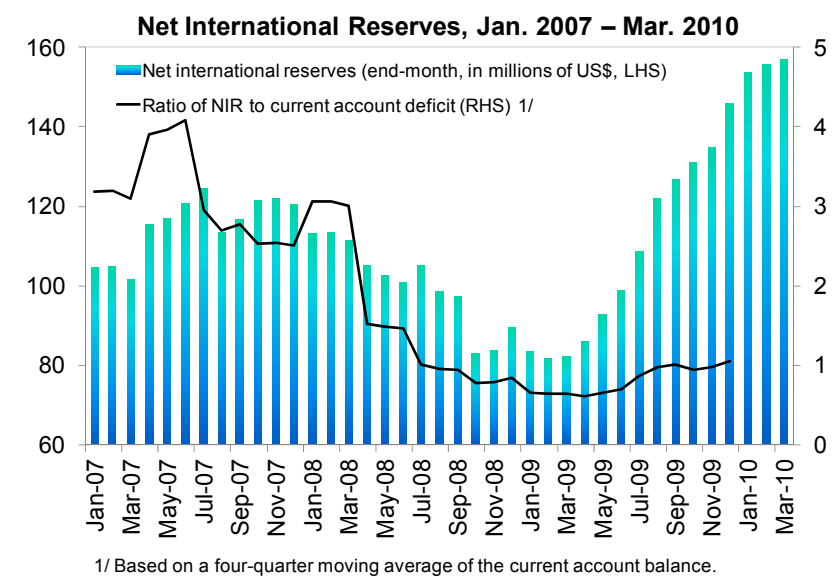

Sources: Data provided by the Solomon Islands authorities; and IMF staff estimates. 
Figure 2. Solomon Islands: Macroeconomic Developments
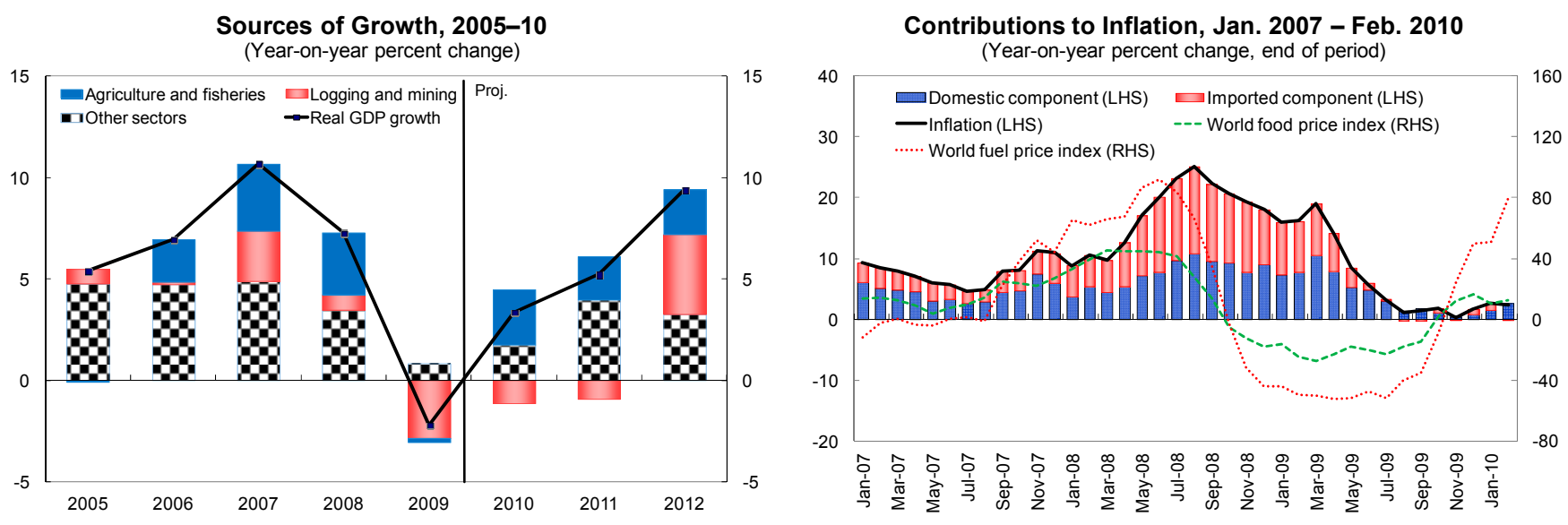

Current Account Balance and Gross Official Reserves, 2005-12 (In percent of GDP, unless otherwise indicated)

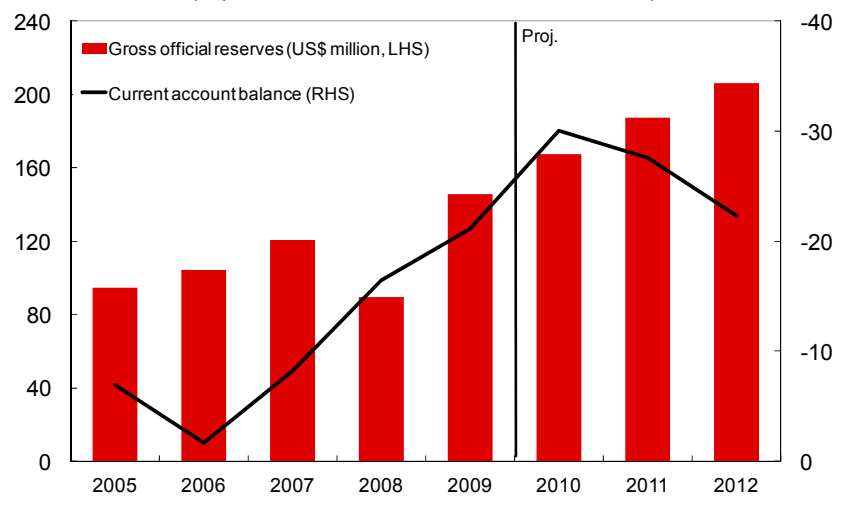

Reserve Change Decomposition, 2005-12 (Contribution to reserves, in US\$ millions)

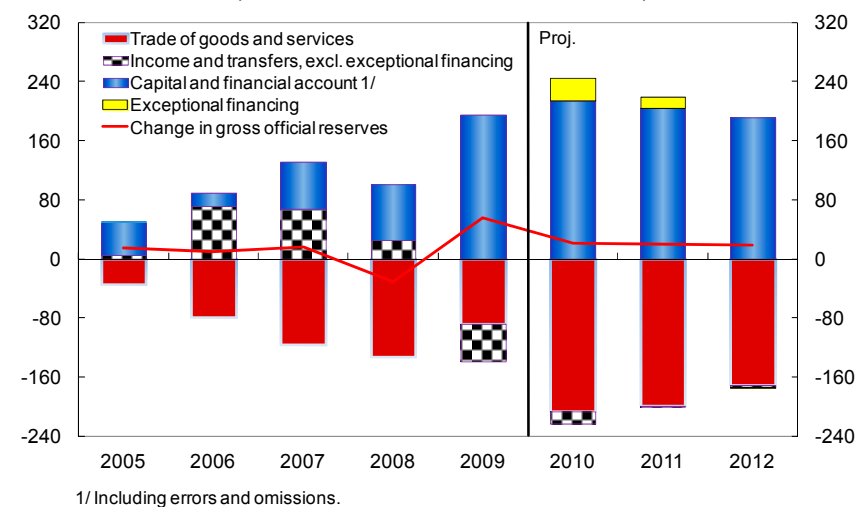

Export Developments, 2005-12
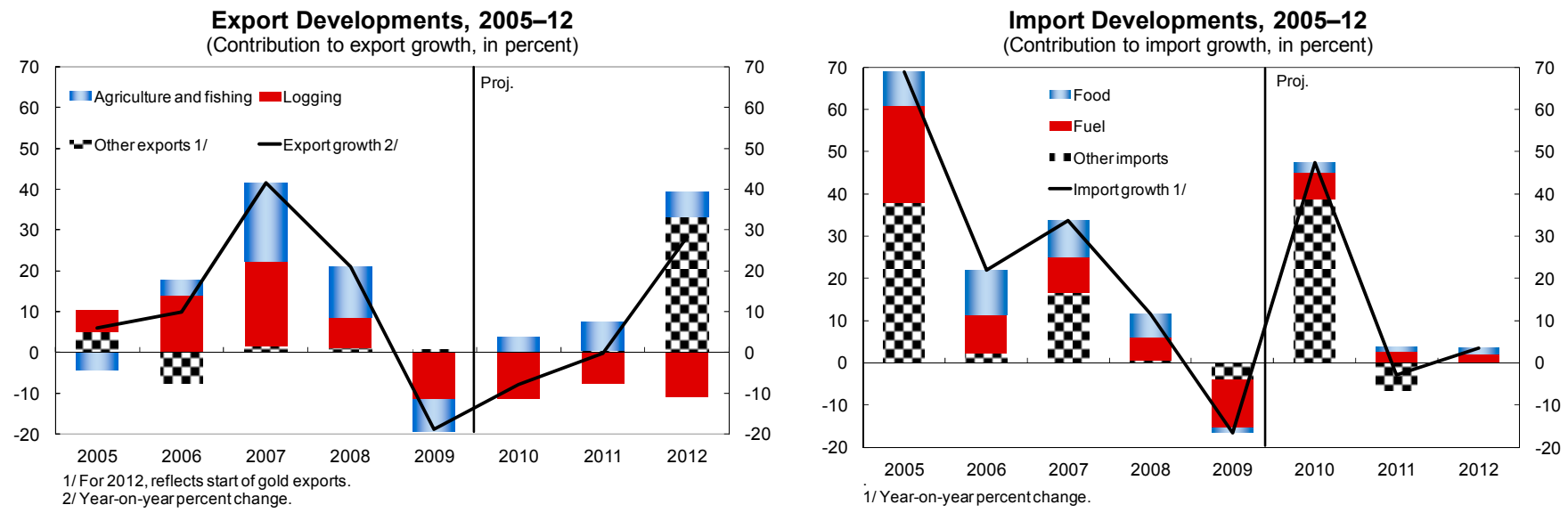

Sources: Data provided by the Solomon Islands authorities; and IMF staff estimates and projections. 
Figure 2. Solomon Islands: Macroeconomic Developments (concluded)

Fiscal Balance and Financing, 2005-12

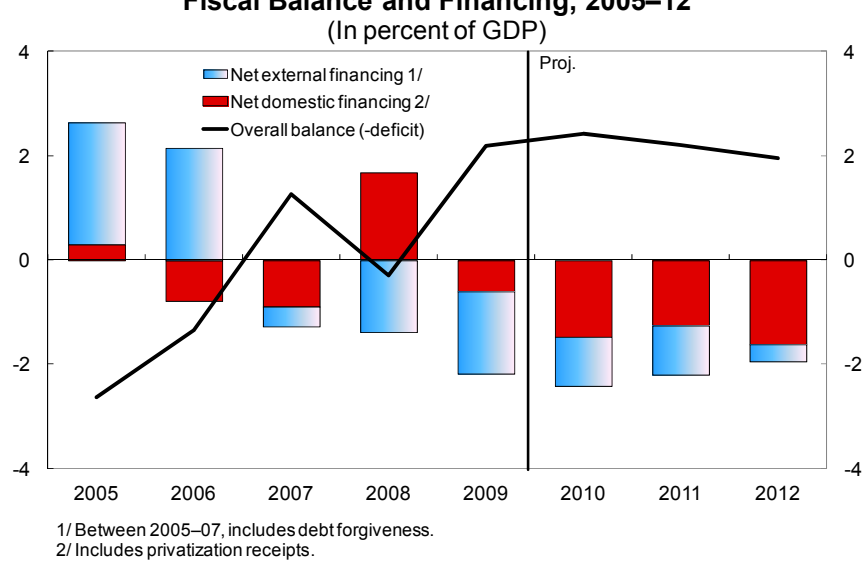

Monetary Developments, Jan. 2007 - Feb. 2010 (Contribution to broad money growth, in percent)

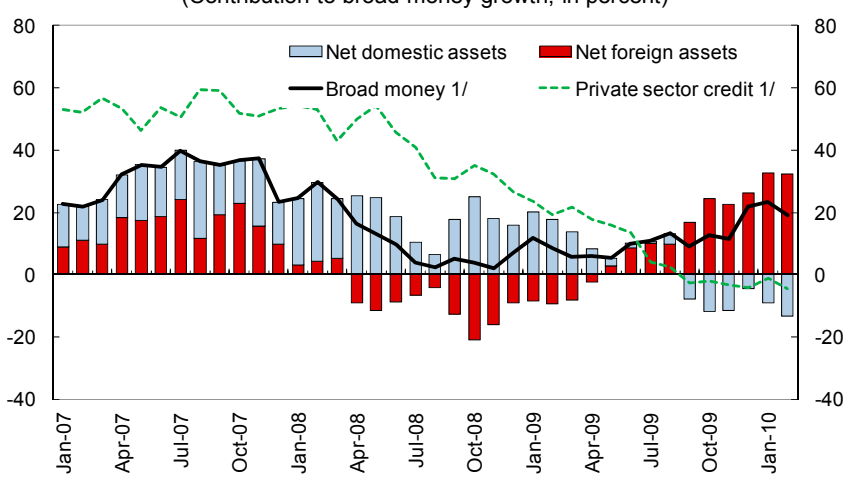

1/Year-on-year percentchange.

Interest Rates and Excess Reserves, Jan. 2007 - Feb. 2010

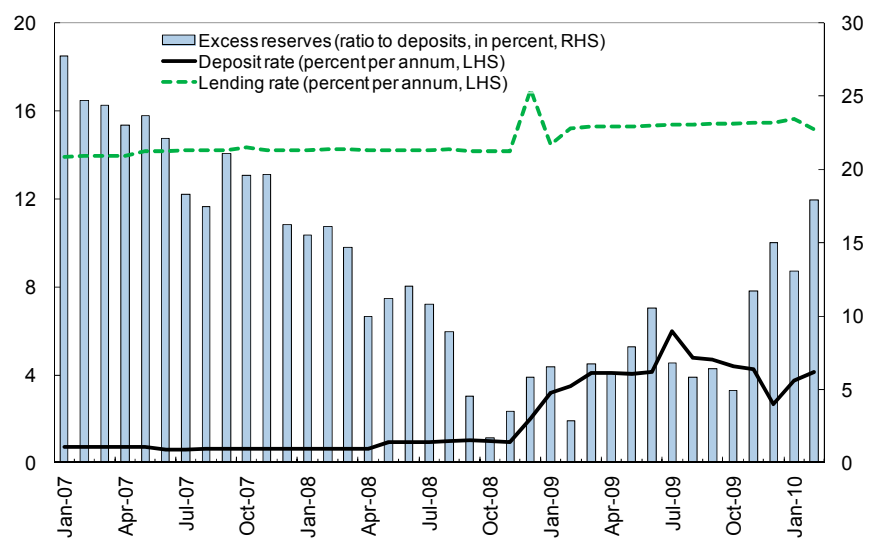

Public External Debt, 2005-12

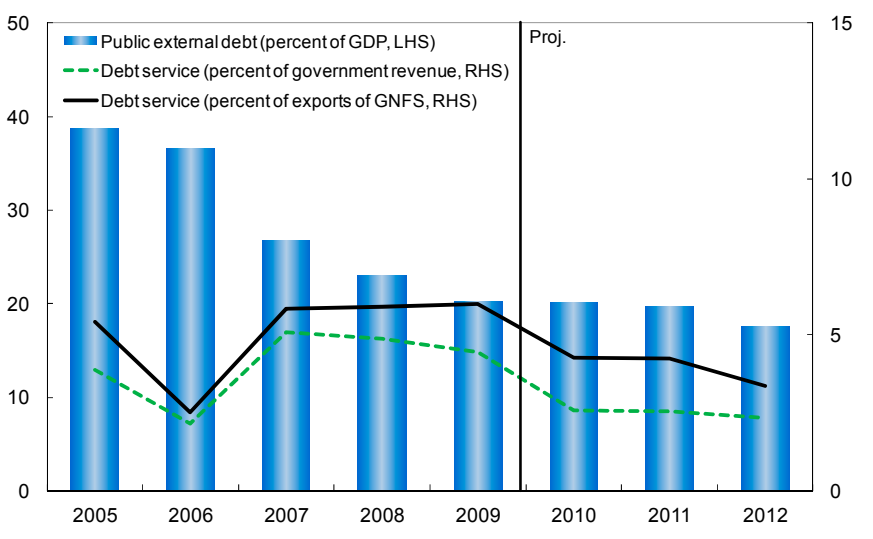

Deposit and Credit Growth, Jan. 2007 - Feb. 2010 (Year-on-year percent change)

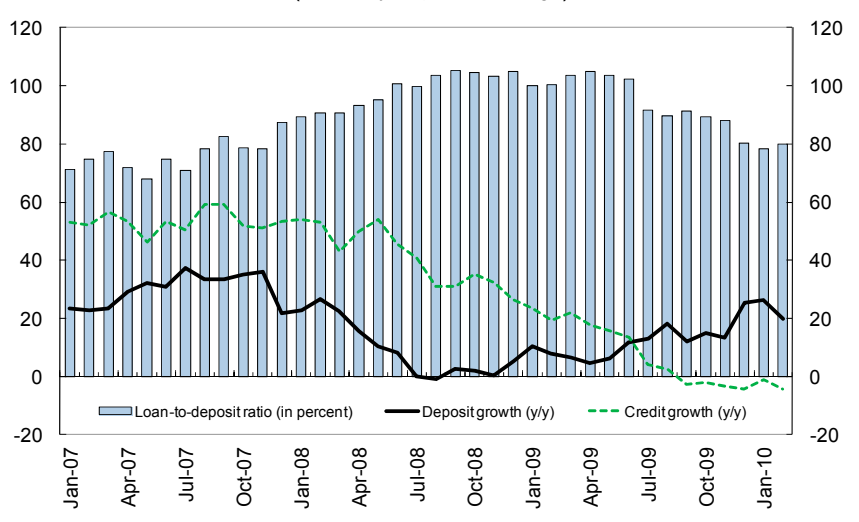

Nominal and Effective Exchange Rates, Jan. 2005 - Feb. 2010

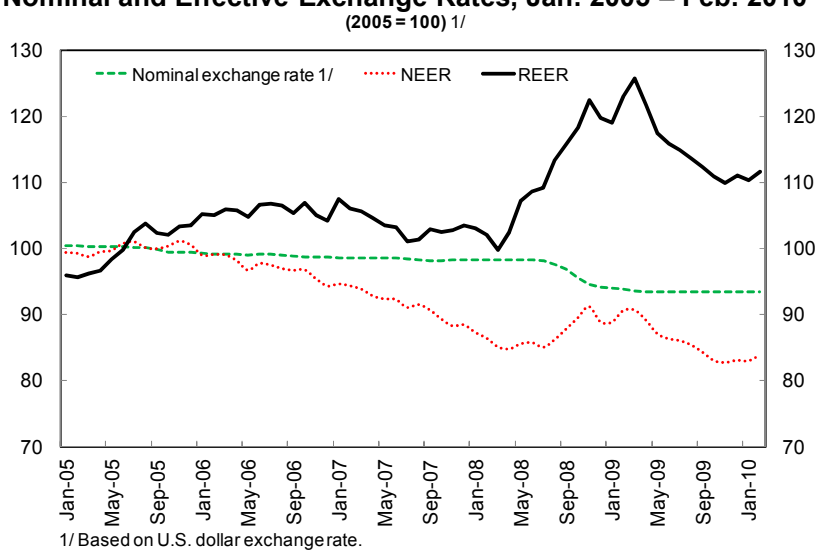

Sources: Data provided by the Solomon Islands authorities; and IMF staff estimates and projections. 
Table 1. Solomon Islands: Selected Economic Indicators, 2007-11

Nominal GDP (2009): US\$657 million (estimate)

Population (2009): 518 thousand (estimate)

\begin{tabular}{|c|c|c|c|c|c|}
\hline & \multirow[t]{2}{*}{2007} & \multirow[t]{2}{*}{2008} & 2009 & 2010 & 2011 \\
\hline & & & Est. & \multicolumn{2}{|c|}{ Proj. } \\
\hline \multicolumn{6}{|l|}{ Growth and prices (percentage change) } \\
\hline Real GDP & 10.7 & 7.3 & -2.2 & 3.4 & 5.2 \\
\hline $\mathrm{CPI}$ (period average) & 7.7 & 17.4 & 7.1 & 4.8 & 6.2 \\
\hline $\mathrm{CPI}$ (end of period) & 10.9 & 18.1 & 1.8 & 6.5 & 6.0 \\
\hline GDP deflator & 16.6 & 4.0 & 8.1 & 2.1 & 3.6 \\
\hline Nominal GDP (in SI\$ millions) & 4,485 & 5,004 & 5,291 & 5,581 & 6,083 \\
\hline Per capita GDP (in US\$) & 1,184 & 1,274 & 1,268 & 1,269 & 1,296 \\
\hline Per capita GNI (in US\$) & 1,110 & 1,088 & 927 & 958 & 1,009 \\
\hline \multicolumn{6}{|l|}{ Central government operations (percent of GDP) } \\
\hline Total revenue and grants & 42.1 & 45.2 & 45.3 & 51.8 & 51.2 \\
\hline Revenue & 24.8 & 27.3 & 27.1 & 27.9 & 29.6 \\
\hline Grants & 17.3 & 17.9 & 18.2 & 23.9 & 21.6 \\
\hline Total expenditure & 40.8 & 45.5 & 43.1 & 49.4 & 49.0 \\
\hline Recurrent expenditure & 21.8 & 23.8 & 23.2 & 26.7 & 25.8 \\
\hline Development expenditure & 18.1 & 19.7 & 19.1 & 22.4 & 22.9 \\
\hline Unrecorded expenditure 1/ & 0.9 & 1.9 & 0.8 & 0.4 & 0.3 \\
\hline Overall balance & 1.3 & -0.3 & 2.2 & 2.4 & 2.2 \\
\hline Foreign financing (net) & -0.4 & -1.4 & -1.6 & -1.0 & -1.0 \\
\hline Domestic financing (net) & -0.9 & 1.7 & -1.5 & -1.8 & -1.3 \\
\hline Privatization receipts & 0.0 & 0.0 & 0.8 & 0.4 & 0.0 \\
\hline Central government debt (percent of GDP, unless otherwise indicated) 2/ & 36.8 & 32.1 & 28.3 & 26.8 & 24.9 \\
\hline Domestic debt & 10.1 & 9.1 & 8.0 & 6.7 & 5.2 \\
\hline External debt & 26.8 & 23.0 & 20.2 & 20.2 & 19.7 \\
\hline (In US\$ millions, end of period) & 156.6 & 143.6 & 132.8 & 133.1 & 136.0 \\
\hline \multicolumn{6}{|l|}{ Monetary and credit (percentage change, end-year data) } \\
\hline Credit to private sector & 53.3 & 26.5 & -4.2 & 12.2 & 18.8 \\
\hline Broad money & 23.3 & 6.9 & 22.0 & 7.0 & 12.5 \\
\hline Reserve money & -6.0 & -2.3 & 53.5 & -0.5 & 12.3 \\
\hline Interest rate - deposit (percent per annum) & 0.7 & 2.0 & 2.7 & $\ldots$ & $\ldots$ \\
\hline Interest rate - lending (percent per annum) & 14.2 & 17.0 & 15.4 & $\ldots$ & $\ldots$ \\
\hline \multicolumn{6}{|l|}{ Balance of payments (in US\$ millions, unless otherwise indicated) } \\
\hline Current account balance & -48.0 & -106.1 & -138.7 & -202.5 & -193.7 \\
\hline (Percent of GDP) & -8.2 & -16.4 & -21.1 & -30.1 & -27.6 \\
\hline Exports of goods and nonfactor services & 215.0 & 240.9 & 220.3 & 211.1 & 216.5 \\
\hline (Percentage change) & 32.5 & 12.0 & -8.5 & -4.2 & 2.6 \\
\hline Imports of goods and nonfactor services & 330.5 & 373.0 & 308.3 & 417.6 & 415.3 \\
\hline (Percentage change) & 36.8 & 12.9 & -17.3 & 35.5 & -0.6 \\
\hline Overall balance & 16.2 & -31.0 & 56.4 & 11.8 & 10.2 \\
\hline Gross official reserves (in US\$ millions, end of period) $3 /$ & 120.5 & 89.5 & 146.0 & 167.5 & 187.3 \\
\hline (In months of next year's imports of goods and nonfactor services) & 3.9 & 3.5 & 4.2 & 4.8 & 5.2 \\
\hline Exchange rate (SI\$/US\$, end of period) & 7.66 & 8.00 & 8.06 & $\ldots$ & $\ldots$ \\
\hline Real effective exchange rate (period average, $2005=100$ ) & 106.5 & 114.2 & 119.9 & $\ldots$ & $\ldots$ \\
\hline Nominal effective exchange rate (period average, $2005=100$ ) & 93.1 & 88.7 & 88.5 & $\ldots$ & $\ldots$ \\
\hline
\end{tabular}

Sources: Data provided by the authorities; and IMF staff estimates and projections.

$1 /$ Includes the change in stock of unpaid payment orders and unpresented checks.

2/ Includes disbursements under an IMF-supported arrangement.

3/ Includes SDR allocations made by the IMF to the Solomon Islands in 2009 and prospective disbursements under an IMF-supported arrangement. 
Table 2. Solomon Islands: Balance of Payments, 2007-12

(In millions of U.S. dollars)

\begin{tabular}{|c|c|c|c|c|c|c|}
\hline & \multirow[t]{2}{*}{2007} & \multirow[t]{2}{*}{2008} & \multirow{2}{*}{$\frac{2009}{\text { Est. }}$} & 2010 & 2011 & 2012 \\
\hline & & & & \multicolumn{3}{|c|}{ Proj. } \\
\hline Current account balance & -48.0 & -106.1 & -138.7 & -202.5 & -193.7 & -172.7 \\
\hline Trade balance for goods & -75.0 & -68.8 & -61.9 & -177.9 & -169.0 & -138.9 \\
\hline Exports & 159.6 & 193.3 & 157.0 & 144.7 & 144.5 & 185.3 \\
\hline Logs & 100.2 & 110.3 & 88.2 & 71.4 & 61.2 & 46.3 \\
\hline Fish & 20.6 & 15.2 & 16.2 & 18.5 & 20.9 & 22.5 \\
\hline Minerals & 0.8 & 2.6 & 3.7 & 3.9 & 4.2 & 51.7 \\
\hline Other & 37.9 & 65.2 & 48.9 & 50.9 & 58.1 & 64.7 \\
\hline Imports & -234.6 & -262.1 & -218.8 & -322.6 & -313.5 & -324.2 \\
\hline Food & -50.5 & -63.5 & -60.4 & -65.2 & -68.4 & -72.3 \\
\hline Fuel & -71.1 & -84.4 & -54.4 & -68.1 & -76.9 & -83.4 \\
\hline Other & -113.0 & -114.2 & -104.0 & -189.2 & -168.2 & -168.5 \\
\hline Trade balance for services & -40.5 & -63.3 & -26.1 & -28.7 & -29.8 & -32.2 \\
\hline Exports & 55.4 & 47.6 & 63.4 & 66.4 & 72.0 & 77.7 \\
\hline Imports & -95.9 & -110.9 & -89.5 & -95.0 & -101.8 & -110.0 \\
\hline Income balance & -36.5 & -94.3 & -176.7 & -165.2 & -155.9 & -157.2 \\
\hline Current transfers balance $1 /$ & 104.1 & 120.3 & 125.9 & 169.3 & 160.9 & 155.6 \\
\hline Of which: Official transfers, net & 87.0 & 109.4 & 104.5 & 147.3 & 138.0 & 130.3 \\
\hline European Union budget support (expected) & $\ldots$ & $\ldots$ & $\ldots$ & 20.9 & 5.5 & $\ldots$ \\
\hline Capital account balance & 14.4 & 6.9 & 13.0 & 12.9 & 13.6 & 13.2 \\
\hline Financial account balance & 57.4 & 81.8 & 163.3 & 201.3 & 190.3 & 178.6 \\
\hline Direct investment balance & 56.9 & 86.0 & 125.7 & 207.0 & 198.1 & 183.8 \\
\hline Other investment balance $2 /$ & 0.5 & -4.2 & 37.6 & -5.7 & -7.8 & -5.1 \\
\hline Errors and omissions & -7.6 & -13.6 & 18.9 & 0.0 & 0.0 & 0.0 \\
\hline Overall balance & 16.2 & -31.0 & 56.4 & 11.8 & 10.2 & 19.2 \\
\hline Financing & -16.2 & 31.0 & -56.4 & -11.8 & -10.2 & -19.2 \\
\hline Change in gross reserves $(-=$ increase $)$ & -16.2 & 31.0 & -56.4 & -21.5 & -19.8 & -19.1 \\
\hline IMF (prospective arrangement) & $\ldots$ & $\ldots$ & $\ldots$ & 9.7 & 9.6 & -0.1 \\
\hline \multicolumn{7}{|l|}{ Memorandum items: } \\
\hline Current account (in percent of GDP) & -8.2 & -16.4 & -21.1 & -30.1 & -27.6 & -22.3 \\
\hline (excluding mining-related capital imports) & $\ldots$ & & $\ldots$ & -21.6 & -20.3 & -16.9 \\
\hline (excluding net official transfers) & -23.0 & -33.4 & -37.0 & -51.9 & -47.2 & -39.1 \\
\hline Net international reserves $2 /$ & 120.5 & 89.5 & 146.0 & 157.8 & 168.0 & 187.2 \\
\hline Gross official foreign reserves $2 / 3 /$ & 120.5 & 89.5 & 146.0 & 167.5 & 187.3 & 206.4 \\
\hline In months of next year's GNFS & 3.9 & 3.5 & 4.2 & 4.8 & 5.2 & 5.3 \\
\hline In months of nonmining-related imports of GNFS & $\ldots$ & $\ldots$ & 4.9 & 5.5 & 5.7 & 5.9 \\
\hline Gross external public debt (in percent of GDP) & 26.8 & 23.0 & 20.2 & 20.2 & 19.7 & 17.5 \\
\hline External public debt service (in percent of GDP) & 2.1 & 2.2 & 2.0 & 1.3 & 1.1 & 1.0 \\
\hline Nominal GDP & 586.1 & 645.8 & 657.1 & $\ldots$ & $\ldots$ & $\ldots$ \\
\hline
\end{tabular}

Sources: Data provided by the Solomon Islands authorities; and IMF staff estimates and projections.

1/ For 2010-11, includes additional donor support expected under a prospective IMF-supported arrangement.

2/ Includes the SDR allocations made by the IMF in 2009.

$3 /$ Includes disbursements under a prospective IMF-supported arrangement. 
Table 3. Solomon Islands: Summary of Fiscal Accounts, 2007-11

\begin{tabular}{|c|c|c|c|c|c|c|}
\hline & \multirow[t]{2}{*}{2007} & \multirow[t]{2}{*}{2008} & \multirow{2}{*}{$\frac{2009}{\text { Est. }}$} & \multicolumn{2}{|c|}{2010} & \multirow{2}{*}{$\frac{2011}{\text { Prog. }}$} \\
\hline & & & & Budget & Prog. & \\
\hline & \multicolumn{5}{|c|}{ (In millions of Solomon Islands dollars) } & \\
\hline Total revenue and grants & 1,887 & 2,260 & 2,396 & 3,059 & 2,894 & 3,115 \\
\hline Total revenue & 1,113 & 1,366 & 1,433 & 1,644 & 1,559 & 1,802 \\
\hline Tax revenue & 931 & 1,199 & 1,260 & 1,430 & 1,357 & 1,551 \\
\hline Income and profits & 297 & 442 & 531 & 519 & 567 & 652 \\
\hline Goods and services & 341 & 425 & 420 & 569 & 470 & 536 \\
\hline International trade and transactions & 293 & 332 & 309 & 342 & 320 & 362 \\
\hline Of which: Tax on logging & 179 & 209 & 162 & $\ldots$ & 149 & 142 \\
\hline Other revenue & 182 & 167 & 173 & 214 & 202 & 251 \\
\hline Grants & 774 & 894 & 963 & 1,415 & 1,335 & 1,314 \\
\hline Development grants- Identified & 746 & 784 & 831 & 1,242 & 993 & 1,089 \\
\hline Recurrent budget grants- Identified & 28 & 109 & 132 & 173 & 173 & 180 \\
\hline Additional donor budget support $1 /$ & 0 & 0 & 0 & 0 & 168 & 44 \\
\hline Expenditure & 1,830 & 2,274 & 2,280 & 3,073 & 2,758 & 2,981 \\
\hline Of which: appropriated 2/ & 1,084 & 1,490 & 1,449 & 1,831 & 1,765 & 1,892 \\
\hline Recurrent expenditure & 977 & 1,189 & 1,228 & 1,536 & 1,490 & 1,569 \\
\hline Compensation of employees & 362 & 453 & 472 & 487 & 515 & 561 \\
\hline Interest payments & 60 & 50 & 33 & 34 & 31 & 31 \\
\hline Other recurrent expenditure & 555 & 686 & 723 & 1,015 & 944 & 978 \\
\hline Development expenditure & 813 & 988 & 1,010 & 1,537 & 1,248 & 1,392 \\
\hline Of which: Domestically financed & 67 & 204 & 179 & 295 & 255 & 302 \\
\hline Unrecorded expenditure $3 /$ & 40 & 97 & 42 & 0 & 20 & 20 \\
\hline Current balance & 164 & 287 & 337 & 281 & 242 & 412 \\
\hline Overall balance & 57 & -14 & 116 & -14 & 135 & 134 \\
\hline (excluding recurrent and additional budget grants) & 29 & -124 & -16 & -187 & -206 & -90 \\
\hline Total financing & -57 & 14 & -116 & 14 & -135 & -134 \\
\hline Foreign (net) & -16 & -69 & -84 & -53 & -53 & -58 \\
\hline Domestic (net) & -40 & 84 & -77 & 47 & -102 & -76 \\
\hline Banking system & -42 & 92 & -64 & 55 & -94 & -67 \\
\hline Central bank & -60 & 96 & -25 & 80 & -105 & -40 \\
\hline Commercial banks & 18 & -4 & -39 & -25 & 11 & -27 \\
\hline Nonbank & 1 & -8 & -13 & -8 & -8 & -9 \\
\hline \multirow[t]{2}{*}{ Privatization receipts 4 / } & 0 & 0 & 45 & 20 & 20 & 0 \\
\hline & \multicolumn{5}{|c|}{ (In percent of GDP) } & \\
\hline Total revenue and grants & 42.1 & 45.2 & 45.3 & 54.8 & 51.8 & 51.2 \\
\hline Total revenue & 24.8 & 27.3 & 27.1 & 29.5 & 27.9 & 29.6 \\
\hline Tax revenue & 20.8 & 24.0 & 23.8 & 25.6 & 24.3 & 25.5 \\
\hline Income and profits & 6.6 & 8.8 & 10.0 & 9.3 & 10.2 & 10.7 \\
\hline Goods and services & 7.6 & 8.5 & 7.9 & 10.2 & 8.4 & 8.8 \\
\hline International trade and transactions & 6.5 & 6.6 & 5.8 & 6.1 & 5.7 & 6.0 \\
\hline Of which: Tax on logging & 4.0 & 4.2 & 3.1 & $\ldots$ & 2.7 & 2.3 \\
\hline Other revenue & 4.0 & 3.3 & 3.3 & 3.8 & 3.6 & 4.1 \\
\hline Grants & 17.3 & 17.9 & 18.2 & 25.4 & 23.9 & 21.6 \\
\hline Expenditure & 40.8 & 45.5 & 43.1 & 55.1 & 49.4 & 49.0 \\
\hline Of which: appropriated 2/ & 24.2 & 29.8 & 27.4 & 32.8 & 31.6 & 31.1 \\
\hline Recurrent expenditure & 21.8 & 23.8 & 23.2 & 27.5 & 26.7 & 25.8 \\
\hline Compensation of employees & 8.1 & 9.1 & 8.9 & 8.7 & 9.2 & 9.2 \\
\hline Interest payments & 1.3 & 1.0 & 0.6 & 0.6 & 0.6 & 0.5 \\
\hline Other recurrent expenditure & 12.4 & 13.7 & 13.7 & 18.2 & 16.9 & 16.1 \\
\hline Development expenditure & 18.1 & 19.7 & 19.1 & 27.5 & 22.4 & 22.9 \\
\hline Of which: Domestically financed & 1.5 & 4.1 & 3.4 & 5.3 & 4.6 & 5.0 \\
\hline Unrecorded expenditure $3 /$ & 0.9 & 1.9 & 0.8 & 0.0 & 0.4 & 0.3 \\
\hline Current balance & 3.6 & 5.7 & 6.4 & 5.0 & 4.3 & 6.8 \\
\hline Overall balance & 1.3 & -0.3 & 2.2 & -0.2 & 2.4 & 2.2 \\
\hline (excluding recurrent and additional budget grants) & 0.6 & -2.5 & -0.3 & -3.3 & -3.7 & -1.5 \\
\hline Total financing & -1.3 & 0.3 & -2.2 & 0.2 & -2.4 & -2.2 \\
\hline Foreign (net) & -0.4 & -1.4 & -1.6 & -1.0 & -1.0 & -1.0 \\
\hline Domestic (net) & -0.9 & 1.7 & -1.5 & 0.8 & -1.8 & -1.3 \\
\hline Privatization receipts $4 /$ & 0.0 & 0.0 & 0.8 & 0.4 & 0.4 & 0.0 \\
\hline \multicolumn{7}{|l|}{ Memorandum items: } \\
\hline Nominal GDP (in SI\$ millions) & 4,485 & 5,004 & 5,291 & 5,581 & 5,581 & 6,083 \\
\hline Gross cash balance (in SI\$ millions) 5/ & 152 & 137 & 106 & $\ldots$ & 206 & 246 \\
\hline Program cash balance (in SI\$ millions) 6/ & $\ldots$ & $\ldots$ & 47 & $\ldots$ & 167 & 227 \\
\hline
\end{tabular}

Sources: Data provided by the Solomon Islands authorities; and IMF staff estimates and projections.

1/ Reflects prospective additional budget support from donors in 2010-11.

2/ Expenditure appropriated or recorded in the government's recurrent and development estimates, including supplemental budget appropriations.

3 / Includes the change in stock of unpaid payment orders and unpresented checks ( $+=$ reduction)

4/ For 2009, includes receipts from the sale of a new telecommunication license of SI\$31 million.

$5 /$ Sum of government deposits in the core cash balance accounts.

6/ The gross cash balance minus unpaid payments orders and unpresented checks. 
Table 4. Solomon Islands: Summary Accounts of the Banking System, December 2008 - December 2011 1/

\begin{tabular}{|c|c|c|c|c|c|c|c|c|c|}
\hline & \multirow{2}{*}{$\frac{2008}{\text { Dec. }}$} & \multirow{2}{*}{$\frac{2009}{\text { Dec. }}$} & \multirow{2}{*}{$\begin{array}{r}2010 \\
\text { Feb. }\end{array}$} & \multicolumn{4}{|c|}{2010} & \multicolumn{2}{|c|}{2011} \\
\hline & & & & $\begin{array}{l}\text { Mar. } \\
\text { Proj. }\end{array}$ & \multicolumn{3}{|c|}{ Prog. } & $\begin{array}{l}\text { Mar. } \\
\text { Prog. }\end{array}$ & $\begin{array}{l}\text { Dec. } \\
\text { Proj. }\end{array}$ \\
\hline & \multicolumn{9}{|c|}{ (In millions of Solomon Islands dollars, end of period) } \\
\hline \multicolumn{10}{|l|}{ Central Bank of Solomon Islands (CBSI) } \\
\hline Net foreign assets (NFA) & 708 & 1,051 & 1,129 & 1,142 & 1,061 & 1,019 & 1,153 & 1,174 & 1,244 \\
\hline Net international reserves (NIR) & 716 & 1,177 & 1,256 & 1,264 & 1,183 & 1,141 & 1,273 & 1,292 & 1,359 \\
\hline Other NFA & -9 & -126 & -127 & -122 & -123 & -121 & -120 & -118 & -116 \\
\hline Net domestic assets (NDA) & -262 & -367 & -360 & -395 & -332 & -327 & -472 & -447 & -479 \\
\hline Net claims on central government & -52 & -77 & -45 & -83 & -52 & -63 & -182 & -144 & -222 \\
\hline Claims & 138 & 124 & 123 & 122 & 122 & 120 & 119 & 119 & 119 \\
\hline Deposits & 190 & 201 & 168 & 206 & 174 & 183 & 301 & 263 & 341 \\
\hline Other items (net) & -210 & -290 & -315 & -312 & -280 & -264 & -290 & -303 & -257 \\
\hline Reserve money & 446 & 684 & 769 & 747 & 729 & 692 & 681 & 727 & 765 \\
\hline Currency in circulation & 273 & 288 & 288 & 301 & 305 & 320 & 342 & 363 & 366 \\
\hline Bank deposits & 166 & 389 & 475 & 444 & 417 & 368 & 336 & 361 & 396 \\
\hline Other deposits & 7 & 6 & 6 & 2 & 6 & 5 & 3 & 3 & 3 \\
\hline \multicolumn{10}{|l|}{ Other depository corporations } \\
\hline NFA of commercial banks & 137 & 181 & 122 & 161 & 153 & 148 & 143 & 146 & 160 \\
\hline Assets & 143 & 184 & 134 & 163 & 155 & 150 & 145 & 148 & 161 \\
\hline Liabilities & 6 & 2 & 12 & 2 & 2 & 2 & 2 & 2 & 2 \\
\hline NDA of commercial banks & 888 & 927 & 888 & 897 & 954 & 1,022 & 1,094 & 1,120 & 1,234 \\
\hline Net claims on central government & 90 & 51 & 65 & 60 & 69 & 65 & 62 & 57 & 35 \\
\hline Claims & 116 & 125 & 118 & 109 & 107 & 103 & 100 & 95 & 74 \\
\hline Deposits & 26 & 74 & 53 & 49 & 38 & 38 & 38 & 38 & 38 \\
\hline Claims on the private sector & 1,274 & 1,219 & 1,205 & 1,222 & 1,256 & 1,317 & 1,368 & 1,427 & 1,625 \\
\hline Other items (net) & -476 & -343 & -382 & -386 & -371 & -360 & -336 & -363 & -426 \\
\hline Reserves and vault cash & 188 & 410 & 496 & 465 & 443 & 397 & 361 & 387 & 422 \\
\hline Deposits & 1,213 & 1,519 & 1,506 & 1,523 & 1,551 & 1,567 & 1,598 & 1,654 & 1,816 \\
\hline \multicolumn{10}{|l|}{ Depository corporations survey } \\
\hline NFA of the banking system & 845 & 1,233 & 1,252 & 1,303 & 1,213 & 1,167 & 1,296 & 1,320 & 1,403 \\
\hline Central bank & 708 & 1,051 & 1,129 & 1,142 & 1,061 & 1,019 & 1,153 & 1,174 & 1,244 \\
\hline Other depository corporations & 137 & 181 & 122 & 161 & 153 & 148 & 143 & 146 & 160 \\
\hline NDA of the banking system & 625 & 560 & 527 & 501 & 622 & 694 & 622 & 673 & 755 \\
\hline Net claims on central government & 38 & -26 & 20 & -23 & 17 & 2 & -120 & -88 & -187 \\
\hline Claims on the private sector $2 /$ & 1,278 & 1,224 & 1,209 & 1,227 & 1,261 & 1,322 & 1,373 & 1,432 & 1,631 \\
\hline Other items (net) & -690 & -637 & -702 & -703 & -655 & -629 & -631 & -671 & -689 \\
\hline Broad money (M3) & 1,470 & 1,793 & 1,779 & 1,804 & 1,836 & 1,861 & 1,919 & 1,993 & 2,158 \\
\hline M1 & 898 & 1,090 & 1,073 & 1,094 & 1,111 & 1,123 & 1,166 & 1,203 & 1,312 \\
\hline Currency outside banks & 250 & 268 & 266 & 279 & 279 & 290 & 317 & 337 & 340 \\
\hline Demand deposits & 648 & 822 & 807 & 814 & 832 & 833 & 849 & 867 & 972 \\
\hline \multirow[t]{2}{*}{ Savings and time deposits } & 572 & 703 & 706 & 710 & 724 & 738 & 752 & 790 & 846 \\
\hline & \multicolumn{9}{|c|}{ (Annual percentage change, unless otherwise indicated) } \\
\hline Reserve money & -2.3 & 53.5 & 57.6 & 78.1 & 74.8 & 37.2 & -0.5 & -2.6 & 12.3 \\
\hline Credit to the private sector & 26.5 & -4.2 & -4.4 & -3.6 & -3.0 & 9.5 & 12.2 & 16.7 & 18.8 \\
\hline Broad money & 6.9 & 22.0 & 19.0 & 24.5 & 22.0 & 21.8 & 7.0 & 10.5 & 12.5 \\
\hline NFA of the banking system 3 / & -9.1 & 26.4 & 32.3 & 37.1 & 15.4 & 5.4 & 3.5 & 1.0 & 5.6 \\
\hline NDA of the banking system $3 /$ & 16.0 & -4.4 & -13.3 & -12.6 & 6.6 & 16.4 & 3.5 & 9.5 & 6.9 \\
\hline \multicolumn{10}{|l|}{ Memorandum items: } \\
\hline Money multiplier & 3.3 & 2.6 & 2.3 & 2.4 & 2.5 & 2.7 & 2.8 & 2.7 & 2.8 \\
\hline Loan to deposit ratio (in percent) & 105.0 & 80.3 & 80.0 & 80.2 & 81.0 & 84.1 & 85.6 & 86.3 & 89.5 \\
\hline \multicolumn{10}{|l|}{ Interest rates (percent per annum) } \\
\hline Deposit rate $4 /$ & 2.0 & 2.7 & 4.1 & $\ldots$ & $\ldots$ & $\ldots$ & $\ldots$ & $\ldots$ & $\ldots$ \\
\hline Lending rate $4 /$ & 17.0 & 15.4 & 15.1 & $\ldots$ & $\ldots$ & $\ldots$ & $\ldots$ & $\ldots$ & $\ldots$ \\
\hline \multicolumn{10}{|l|}{ Program targets } \\
\hline NIR of CBSI (in US\$ millions) & 90 & 146 & $\ldots$ & $\ldots$ & 147 & 141 & 158 & 160 & $\ldots$ \\
\hline NDA of CBSI (in SI\$ millions) & -262 & -367 & $\ldots$ & $\ldots$ & -332 & -327 & -472 & -447 & $\ldots$ \\
\hline
\end{tabular}

Sources: Data provided by the Central Bank of the Solomon Islands; and IMF staff estimates and projections.

$1 /$ Based on the program exchange rate of SI\$8.06 per US\$.

2/ Includes claims of the CBSI on other (nonbank) financial corporations.

$3 /$ Contribution to year-on-year broad money growth, in percentage points.

4/ Weighted average of different maturities. 
Table 5. Solomon Islands: Medium-Term Baseline Scenario, 2008-15 1/

\begin{tabular}{|c|c|c|c|c|c|c|c|c|}
\hline & 2008 & 2009 & 2010 & 2011 & 2012 & 2013 & 2014 & 2015 \\
\hline & & Est. & \multicolumn{6}{|c|}{ Proj. } \\
\hline \multicolumn{9}{|l|}{ Growth and prices (percentage change) } \\
\hline Real GDP & 7.3 & -2.2 & 3.4 & 5.2 & 9.4 & 8.2 & 7.2 & 10.5 \\
\hline $\mathrm{CPI}$ (period average) & 17.4 & 7.1 & 4.8 & 6.2 & 4.7 & 5.6 & 5.4 & 5.2 \\
\hline $\mathrm{CPI}$ (end of period) & 18.1 & 1.8 & 6.5 & 6.0 & 5.7 & 5.6 & 5.3 & 5.0 \\
\hline GDP deflator & 4.0 & 8.1 & 2.1 & 3.6 & 4.1 & 6.5 & 6.8 & 6.9 \\
\hline Nominal GDP (in SI\$ millions) & 5,004 & 5,291 & 5,581 & 6,083 & 6,932 & 7,989 & 9,147 & 10,802 \\
\hline Per capita GDP (in US\$) & 1,274 & 1,268 & 1,269 & 1,296 & 1,399 & 1,527 & 1,661 & 1,866 \\
\hline Per capita GNI (in US\$) & 1,088 & 927 & 958 & 1,009 & 1,115 & 1,239 & 1,375 & 1,585 \\
\hline \multicolumn{9}{|l|}{ Central government operations (percent of GDP) } \\
\hline Total revenue and grants & 45.2 & 45.3 & 51.8 & 51.2 & 48.9 & 47.0 & 45.7 & 44.3 \\
\hline Recurrent revenue & 27.3 & 27.1 & 27.9 & 29.6 & 30.3 & 30.6 & 31.0 & 31.5 \\
\hline Grants & 17.9 & 18.2 & 23.9 & 21.6 & 18.6 & 16.4 & 14.7 & 12.8 \\
\hline Total expenditure & 45.5 & 43.1 & 49.4 & 49.0 & 46.9 & 45.3 & 44.1 & 42.9 \\
\hline Recurrent expenditure & 23.8 & 23.2 & 26.7 & 25.8 & 25.2 & 24.9 & 24.8 & 25.0 \\
\hline Development expenditure & 19.7 & 19.1 & 22.4 & 22.9 & 21.8 & 20.3 & 19.3 & 17.8 \\
\hline Unrecorded expenditure 2/ & 1.9 & 0.8 & 0.4 & 0.3 & 0.0 & 0.0 & 0.0 & 0.0 \\
\hline Current balance & 5.7 & 6.4 & 4.3 & 6.8 & 7.6 & 7.9 & 8.2 & 8.2 \\
\hline Overall balance & -0.3 & 2.2 & 2.4 & 2.2 & 2.0 & 1.8 & 1.6 & 1.5 \\
\hline Central government debt (percent of GDP) 3/ & 32.1 & 28.3 & 26.8 & 24.9 & 21.4 & 18.5 & 16.3 & 13.9 \\
\hline \multicolumn{9}{|l|}{ Balance of payments (in US\$ millions) } \\
\hline Current account (balance (- deficit) & -106.1 & -138.7 & -202.5 & -193.7 & -172.7 & -172.7 & -341.2 & -361.0 \\
\hline (In percent of GDP) & -16.4 & -21.1 & -30.1 & -27.6 & -22.3 & -20.0 & -35.6 & -32.9 \\
\hline (excluding mining-related capital imports, in percent of GDP) & $\ldots$ & $\ldots$ & -21.6 & -20.3 & -16.9 & -14.1 & -8.2 & -1.2 \\
\hline Overall balance & -31.0 & 56.4 & 11.8 & 10.2 & 19.2 & 25.1 & 99.8 & 166.5 \\
\hline Gross official reserves (end of period) $4 /$ & 89.5 & 146.0 & 167.5 & 187.3 & 206.4 & 231.4 & 329.5 & 665.3 \\
\hline (In months of next year's imports of GNFS) & 3.5 & 4.2 & 4.8 & 5.2 & 5.3 & 4.1 & 5.1 & 6.6 \\
\hline (In months of next year's nonmining-related imports of GNFS) & $\ldots$ & 4.9 & 5.5 & 5.7 & 5.9 & 6.7 & 9.1 & 12.8 \\
\hline
\end{tabular}

Sources: Data provided by the authorities; and IMF staff estimates and projections.

1/ Projections incorporate expected impact of new gold (2012) and nickel (2015) mining operations.

$2 /$ Includes the change in stock of unpaid payment orders and unpresented checks.

$3 /$ Includes privatization receipts, changes in arrears, and unidentified financing.

4/ Includes SDR allocations made by the IMF to the Solomon Islands in 2009 and prospective disbursements under an IMF-supported arrangement. 
Table 6. Solomon Island: Reviews and Disbursement Under the Proposed Standby Credit Facility

\begin{tabular}{|c|c|c|c|}
\hline \multirow[t]{2}{*}{ Date } & \multicolumn{2}{|c|}{ Amount of Purchase } & \multirow[t]{2}{*}{ Condition } \\
\hline & In percent of quota & In SDR & \\
\hline June 2, 2010 & 30 & $3,120,000$ & Approved Fund arrangement \\
\hline November 26, 2010 & 30 & $3,120,000$ & $\begin{array}{l}\text { Completion of the first review and observance of end- } \\
\text { June } 2010 \text { performance criteria }\end{array}$ \\
\hline May 26, 2011 & 30 & $3,120,000$ & $\begin{array}{l}\text { Completion of the second review and observance of } \\
\text { end-December } 2010 \text { performance criteria }\end{array}$ \\
\hline November 26, 2011 & 30 & $3,120,000$ & $\begin{array}{l}\text { Completion of the third review and observance of end- } \\
\text { June } 2011 \text { performance criteria }\end{array}$ \\
\hline Total & 120 & $12,480,000$ & \\
\hline
\end{tabular}

Source: IMF. 
Table 7. Solomon Islands: External Financing Requirements and Sources, 2009-12

(In millions of U.S. dollars)

\begin{tabular}{|c|c|c|c|c|}
\hline & \multirow{2}{*}{$\frac{2009}{\text { Est. }}$} & 2010 & 2011 & 2012 \\
\hline & & \multicolumn{3}{|c|}{ Proj. } \\
\hline Gross financing requirements & 250 & 369 & 351 & 324 \\
\hline External current account deficit & 139 & 202 & 194 & 173 \\
\hline Amortization of medium- and long-term debt & 11 & 7 & 7 & 7 \\
\hline Gross reserves accumulation $(+=$ increase) & 56 & 21 & 20 & 19 \\
\hline IMF repayments & 0 & 0 & 0 & 0 \\
\hline Other net capital outflows & 43 & 138 & 130 & 125 \\
\hline Available financing & 250 & 339 & 336 & 324 \\
\hline Grants and other official transfers 1/ & 110 & 132 & 138 & 136 \\
\hline Loan disbursement to public sector & 0 & 0 & 0 & 4 \\
\hline SDR allocation & 15 & 0 & 0 & 0 \\
\hline Foreign direct investment, net & 126 & 207 & 198 & 184 \\
\hline Exceptional financing & 0 & 31 & 15 & 0 \\
\hline IMF: prospective arrangement & 0 & 10 & 10 & 0 \\
\hline European Union: budget support & 0 & 21 & 6 & 0 \\
\hline
\end{tabular}

Sources: Data provided by the Solomon Islands authorities; and IMF staff estimates and projections.

1/ Excludes exceptional budget support 
Table 8. Solomon Islands: Indicators of Capacity to Repay the Fund, 2009-19

\begin{tabular}{|c|c|c|c|c|c|c|c|c|c|c|c|}
\hline & 2009 & 2010 & 2011 & 2012 & 2013 & 2014 & 2015 & 2016 & 2017 & 2018 & 2019 \\
\hline & Est. & \multicolumn{10}{|c|}{ Proj. } \\
\hline \multicolumn{12}{|c|}{ Fund obligations based on existing credit (in SDR millions) } \\
\hline Principal & 0.0 & 0.0 & 0.0 & 0.0 & 0.0 & 0.0 & 0.0 & 0.0 & 0.0 & 0.0 & 0.0 \\
\hline Charges and interest & 0.0 & 0.0 & 0.0 & 0.0 & 0.0 & 0.0 & 0.0 & 0.0 & 0.0 & 0.0 & 0.0 \\
\hline \multicolumn{12}{|c|}{ Fund obligations based on existing and prospective credit (in SDR millions) } \\
\hline Principal & 0.0 & 0.0 & 0.0 & 0.0 & 0.0 & 1.0 & 2.4 & 2.8 & 2.8 & 2.4 & 1.0 \\
\hline Charges and interest & 0.0 & 0.0 & 0.0 & 0.1 & 0.1 & 0.1 & 0.1 & 0.0 & 0.0 & 0.0 & 0.0 \\
\hline \multicolumn{12}{|c|}{ Total obligations based on existing and prospective credit } \\
\hline In millions of SDRs & 0.0 & 0.0 & 0.0 & 0.1 & 0.1 & 1.1 & 2.5 & 2.8 & 2.8 & 2.4 & 1.0 \\
\hline In millions of US\$ & 0.0 & 0.0 & 0.0 & 0.1 & 0.1 & 1.7 & 3.8 & 4.4 & 4.3 & 3.8 & 1.6 \\
\hline In percent of gross international reserves & 0.0 & 0.0 & 0.0 & 0.0 & 0.0 & 0.5 & 0.8 & 0.7 & 0.6 & 0.5 & 0.2 \\
\hline In percent of exports of goods and services & 0.0 & 0.0 & 0.0 & 0.0 & 0.0 & 0.5 & 0.9 & 0.9 & 0.8 & 0.7 & 0.3 \\
\hline In percent of debt service $1 /$ & 0.0 & 0.0 & 0.0 & 0.9 & 0.9 & 14.0 & 27.7 & 30.4 & 30.3 & 27.5 & 14.0 \\
\hline In percent of GDP & 0.0 & 0.0 & 0.0 & 0.0 & 0.0 & 0.2 & 0.3 & 0.4 & 0.3 & 0.3 & 0.1 \\
\hline In percent of quota & 0.0 & 0.0 & 0.0 & 0.6 & 0.6 & 10.6 & 23.8 & 27.0 & 26.9 & 23.4 & 10.0 \\
\hline \multicolumn{12}{|l|}{ Outstanding Fund credit } \\
\hline In millions of SDRs & 0.0 & 6.2 & 12.5 & 12.5 & 12.5 & 11.4 & 9.0 & 6.2 & 3.5 & 1.0 & 0.0 \\
\hline In millions of US\$ & 0.0 & 9.7 & 19.3 & 19.3 & 19.3 & 17.7 & 13.9 & 9.7 & 5.4 & 1.6 & 0.0 \\
\hline In percent of gross international reserves & 0.0 & 5.8 & 10.3 & 9.4 & 8.3 & 5.4 & 2.8 & 1.5 & 0.7 & 0.2 & 0.0 \\
\hline In percent of exports of goods and services & 0.0 & 4.6 & 8.9 & 7.3 & 6.4 & 5.2 & 3.3 & 2.0 & 1.0 & 0.3 & 0.0 \\
\hline In percent of debt service $1 /$ & 0.0 & 90.6 & 178.9 & 185.3 & 184.8 & 145.2 & 100.9 & 67.5 & 37.6 & 11.7 & 0.0 \\
\hline In percent of GDP & 0.0 & 1.4 & 2.7 & 2.5 & 2.2 & 1.8 & 1.3 & 0.8 & 0.4 & 0.1 & 0.0 \\
\hline In percent of quota & 0.0 & 60.0 & 120.0 & 120.0 & 120.0 & 110.0 & 86.7 & 60.0 & 33.3 & 10.0 & 0.0 \\
\hline \multicolumn{12}{|l|}{ Net use of Fund credit (in SDR millions) } \\
\hline Disbursements & 0.0 & 6.2 & 6.2 & 0.0 & 0.0 & 0.0 & 0.0 & 0.0 & 0.0 & 0.0 & 0.0 \\
\hline Repayments and repurchases & 0.0 & 0.0 & 0.0 & 0.1 & 0.1 & 1.1 & 2.5 & 2.8 & 2.8 & 2.4 & 1.0 \\
\hline \multicolumn{12}{|l|}{ Memorandum items: } \\
\hline Nominal GDP (in US\$ millions) & 657 & 674 & 703 & 775 & 864 & 959 & 1,099 & 1,220 & 1,341 & 1,455 & 1,572 \\
\hline Exports of goods and services (in US\$ millions) & 220 & 211 & 216 & 263 & 303 & 340 & 422 & 478 & 535 & 577 & 613 \\
\hline Gross international reserves (in US\$ millions) & 146 & 167 & 187 & 206 & 231 & 330 & 492 & 665 & 745 & 748 & 727 \\
\hline Debt service (in US\$ millions) $1 /$ & 15.3 & 10.6 & 10.8 & 10.4 & 10.5 & 12.2 & 13.8 & 14.3 & 14.3 & 13.7 & 11.6 \\
\hline Quota (in SDR millions) & 10.4 & 10.4 & 10.4 & 10.4 & 10.4 & 10.4 & 10.4 & 10.4 & 10.4 & 10.4 & 10.4 \\
\hline
\end{tabular}

Source: IMF staff estimates and projections

1/ Total public debt service, including IMF repayments. 


\section{APPENDIX I. Letter of Intent}

Mr. Dominique Strauss-Kahn

May 14, 2010

Managing Director

International Monetary Fund

Washington, DC 20431

Dear Mr. Strauss-Kahn:

The Solomon Islands has been affected since late 2008 by the adverse impact of the global economic crisis and a terminal decline in logging output. By our estimates, economic activity contracted in 2009. Inflation declined on falling international fuel and food prices, but also due to weak demand conditions. Reflecting favorable official inflows and the IMF's SDR allocations, our foreign reserves rose, but the situation going forward is uncertain, owing to still challenging global conditions and a fragile recovery at home.

In order to better safeguard our economy against shocks, the Government of Solomon Islands has formulated a set of reforms designed to bolster the fiscal position, maintain a low level of inflation and comfortable level of foreign reserves, and strengthen the financial sector. To help achieve these objectives, we are requesting access to IMF resources under a Standby Credit Facility (SCF) for SDR 12.48 million (equivalent of 120 percent quota) for a period of 18 months. The Government will also secure support from other international financial institutions and bilateral donors.

The attached Memorandum of Economic and Financial Policies (MEFP) describes the Government's policies and objectives during 2010-11, which we believe will put our economy on a path of sustainable and more equitable growth and help advance our poverty alleviation goals. To ensure strong performance under a SCF-supported arrangement, the government will maintain a close policy dialogue with the IMF and pursue technical assistance, as necessary, from the Fund and other development partners in support of our reform agenda. We stand ready to take additional measures, as appropriate, to ensure the achievement of the government's social and economic objectives under the SCF. In keeping with this, we will consult with the IMF on the adoption of measures, and in advance of revisions to the policies contained in the MEFP, in accordance with the Fund's policies on such matters. Moreover, we will provide the Fund with information in connection with our progress in implementing the policies and achieving the objectives of the program. We also authorize publication of the attached MEFP.

Sincerely yours,

/s/

Hon. Francis Billy Hilly, MP

Minister of Finance and Treasury

Ministry of Finance and Treasury /s/

Denton Rawara

Governor

Central Bank of Solomon Islands

Attachments: Memorandum of Economic and Financial Policies and Technical Memorandum of Understanding 


\section{Memorandum of Economic and Financial Policies}

This memorandum sets forth economic and financial policies and objectives of the Government of the Solomon Islands for the period 2010-11. Under a requested Standby Credit Facility (SCF) arrangement, the government seeks to strengthen macroeconomic management and reduce underlying fiscal and external imbalances. The objective of our program is to build a path back to strong, sustainable, and equitable growth with low inflation, providing a sound basis to advance our poverty alleviation efforts. Its core elements are to strengthen government finance, improve monetary operations, safeguard international reserves, and contain financial sector risks. Quantitative targets and structural policies underlying our program are summarized in Tables 1 and 2. The first and second reviews are expected to be completed no later than November 25, 2010 and May 25, 2011, respectively.

\section{Macroeconomic Outlook}

1. Economic performance weakened in 2009, due to adverse global conditions and a logging output decline. Our preliminary estimates indicate real GDP declined by $2 \frac{1}{4}$ percent. Inflation pressures eased with falling fuel and food prices. Given sluggish domestic demand, bank credit contracted. Reflecting a weak external environment, the current account deficit widened to 21 percent of GDP in 2009. However, given strong official inflows, sizable reinvested earnings, and the SDR allocations, official reserves rose by more than half in 2009 to US\$146 million at year end (4 months of next year's imports).

2. The government's weak cash position and implementation capacity limited its fiscal policy response to the slowdown in 2009. Based on the latest estimates, a budget surplus equivalent of $2 \frac{1}{4}$ percent of GDP was generated in 2009. Despite the fact that we managed to increase our revenue effort through concerted tax and compliance measures, fiscal revenue fell far short of the budgeted target owing largely to the weak economy. In response, outstanding payment orders were periodically delayed to conserve cash and recurrent spending cuts had to be made. However, our gross cash balance further tightened, ending 2009 at around SI\$106 million (3 to 4 weeks of recurrent spending).

3. Macroeconomic conditions are expected to remain challenging in 2010 and 2011. Growth is projected to rise to $3 \frac{1}{2}$ percent in 2010, in line with the global recovery envisaged in the IMF's latest World Economic Outlook, boosting agricultural and fish output. The more stable conditions and the government's liberalization efforts are also expected to bring in new mining and telecommunications investment. However, further declines in logging production will continue to act as a drag on activity. The current account deficit is projected to remain large in 2010 and 2011, in part owing to import requirements associated with foreign direct investment, although we expect medium-term prospects to improve with new gold exports starting in 2012. Under this baseline and assuming sizable exceptional financing, we expect foreign reserves to rise to around US\$168 million by end-2010 and US\$187 million by end2011 (51/4 months of next year's imports).

4. We recognize this outlook is subject to considerable uncertainty, necessitating sound policy execution to entrench macroeconomic stability. Unexpected changes in oil and 
food prices could pass through to inflation and affect the external position. Growth prospects in 2010 and 2011, in particular those related to commodity exports, hinge on the pace of the global economic recovery. In view of this, we recognize the necessity of broad ranging reforms to improve external competitiveness, boost donor and investor confidence, and achieve higher sustained growth.

\section{Program Policies}

\section{Our policies are aimed at maintaining stable macroeconomic conditions, in} support of achieving higher sustained growth and advancing poverty alleviation efforts. In our view, macroeconomic stability is necessary condition for improving the business climate, attracting new investment, including in non-resource sectors, and providing more labor-intensive productive opportunities, all of which are essential to increasing growth. To these ends, the policy framework under our program also seeks to ensure adequate government funding is available for key human development outlays, consistent with improving the quality and availability of education and health services consistent with the Millennium Development Goals.

\section{A. Fiscal Policy}

6. The government has taken steps to strengthen fiscal operations, but sound budget execution requires better revenue administration, cash management, and expenditure prioritization. Through the lead of the Ministry of Finance and Treasury (MoFT), we have substantially enhanced our ability to collect revenue, through both tax and administrative measures. With better enforcement, more space should be created to meet social and development needs. Over the near term, given limited capacity to borrow, our ability to fund the budget will continue to depend on available cash resources, including from recurrent budget support. We recognize immediate fiscal measures are needed to reconstitute cash balances, normalize fiscal operations, and put the Solomon Islands on a more sustainable fiscal path.

\section{In this regard, our key fiscal objectives are to:}

- $\quad$ Address immediate pressures on the cash balance without resorting to delaying payments to creditors or non-prioritized spending reservations;

- $\quad$ Build up a cash reserve fund of around two months of forward recurrent spending by end-2011 to cover the cyclicality in revenue and expenditure flows, potential contingent liabilities, and large shocks necessitating government resources; and

- $\quad$ Provide a lasting framework for ensuring sound budget formulation and implementation, recognizing the strong positive role that potential mining-related revenues may play if managed properly.

We recognize that achieving these objectives will require a fundamental change to our budget strategy and management, in particular as the government assumes a greater responsibility over the medium term for meeting its development and security. To this end, we will take decisive 
steps on our structural fiscal reform agenda, as envisaged below and in line with support from other development partners - most notably the Regional Assistance Mission for Solomon Islands, the Asian Development Bank, and World Bank Group.

8. We are taking strong upfront actions to alleviate cash pressures. A rolling threemonth forward cash forecast for the government's recurrent and development budget has been developed by the MoFT, suggesting significant cash pressures in the near term as revenue is now expected to be weaker than in the 2010 Budget as the economic recovery this year is driven mainly by low-taxed sectors. Consistent with our forecasts, we have taken tough decisions. In the revenue area, we expect new measures to yield at least SI\$24 million (0.4 percent of GDP) in 2010.

- $\quad$ Specifically, we have raised the determined price of logs from US\$77 to US\$83 per cubic meter effective April 1, 2010. In addition, we will introduce an automatic adjustment mechanism for the determined price of logs by end-September 2010, with the determined price adjusted to no less than 85 percent of the formula-based price from October 1, 2010 and with a quarterly phase-in thereafter to achieve the full formula-based price from July 1, 2011. This will align the taxable price more closely with world market prices, enhance revenue collections, and improve overall transparency. In total, we expect these measures will yield SI\$14 million in additional revenue in 2010 .

- We have also strengthened customs enforcement at the wharf and improved compliance through post-clearance audits, supported by the reintroduction of a special customs cargo inspection task force in May 2010 and planned appointment of a Customs Deputy Comptroller. Under these circumstances, we expect a further boost in revenues from last year's hike in excises on beer and tobacco products and new excises on wine and spirits as well increased import duties on personal and luxury vehicles by SI\$ 10 million in 2010, based on performance so far this year.

- $\quad$ Further revenue gains are expected to accrue in the areas of taxpayer registration and audits, while applying successively stronger enforcement actions to collect tax arrears, including, where appropriate, by suspending import licenses and by seizing bank deposits of delinquent taxpayers.

On the expenditure side, we are restraining and reprioritizing outlays in 2010.

- We expect the biggest savings will come from line-item withdrawals of warrants, yielding net savings of at least SI\$116 million (2 percent of GDP). This move will still protect priority programs - especially those funded through education and healthrelated budget support.

- $\quad$ To prevent the emergence of additional spending pressures, we have issued a ministerial circular indicating contingency warrants in 2010 will be fully funded by line-item adjustments to ministerial appropriations or additional revenue measures. As 
a further measure, we intend to cap the government wage bill at SI\$515 million in 2010 and will incorporate all line ministries and employees into the new payroll accounting system by year end to improve accountability and control.

9. We also realize that further concentrated efforts are needed to further strengthen revenue policy and improve tax compliance. We will issue a ministerial circular authorizing annual notification to the Public Accounts Committee of the nature and cost of all tax and customs exemptions granted by end-June 2010. In addition, we will submit to Parliament by end-2010 a set of amendments to the Customs and Excise and Income Tax Acts legalizing exemption criteria and guidelines, including full disclosure requirements, and merging existing exemption committees into a unified committee structure, with the aim of creating a transparent process for granting exemptions. To better capture the actual transaction value of imports, we will amend the new Customs Valuation Act and issue new implementation guidelines by end-2010, bringing the act into full effect by then.

10. With these measures, those committed under other donor programs, and through additional budget support, we will build up a cash buffer the next few years. We will target an overall surplus of around $2 \frac{1}{2}$ percent of GDP in 2010 , to replenish our program cash reserves by SI $\$ 120$ million this year, if necessary through a supplemental appropriation. A further SI\$60 million will be added in 2011 through the annual budget appropriation. The establishment of these reserves and putting the Solomon Islands on a more sustainable fiscal path would send a strong signal to potential new creditors, as we require new sources of funding in the coming years to address growth-critical infrastructure needs and expand the production and employment base.

\section{We have invited the World Bank to work closely with us on a Public Expenditure}

Review (PER) later this year. This exercise will guide our reforms in reorienting expenditure to priority areas. As part of the PER, we plan to develop a better mechanism to track social and other priority spending in order to strengthen monitor the budget's impact on poverty alleviation efforts. Better execution and targeting of the government's own development budget will also require that budget allocations be aligned with spending priorities, notably those set forth in the planned update of the Medium-Term Development Strategy and under the leadership of the Ministry of Development Planning and Aid Coordination. Ongoing efforts to strengthen operational, commercial, and financial performance of state-owned enterprises, with donor support, should minimize potential fiscal risks and assist in settling cross-debts, curtailing the need for government funds.

\section{To maintain budget discipline on a sustained basis, we intend to put on place a} stronger budgetary and institutional framework that guarantees sound fiscal management for this and future governments. We will draft fiscal responsibility provisions into a Fiscal Responsibility Act or amended Public Finance and Audit Act by end-June 2011.

Key provisions would be requirements to update revenue estimates with each supplemental appropriation, to ensure all appropriations are fully funded, and to preserve a cash reserve. The future looks bright with the prospects of mining projects coming on stream in around early 2012. For the people of the Solomon Islands to derive lasting benefits from our natural 
resources, we will adopt a resource tax regime consistent with IMF recommendations by endJune 2011, and, as appropriate, consider subscribing to the Extractive Industries Transparency Initiative.

\section{B. Monetary and Exchange Rate Policy}

13. In light of weak growth momentum and low inflation pressures, we will pursue a moderately accommodative monetary policy. However, the CBSI will continue to monitor inflation and reserves developments carefully and be prepared to tighten monetary policy, as necessary. Monetary targets have been set that provide adequate space to accommodate moderate private sector credit growth over the program period. Given the current de facto peg of the Solomon Islands dollar to the U.S. dollar, fiscal policy will continue to play an essential role in maintaining macroeconomic stability. In this regard, we will ensure net credit to the government and net domestic assets of the Central Bank of Solomon Islands (CBSI) are appropriately restrained.

\section{Building on recent progress, we will take further steps to strengthen our} operational framework and introduce new instruments for conducting monetary policy. The CBSI continues to refine its liquidity forecasting framework, which was introduced in 2009 , to better manage short-term liquidity conditions and develop operational targets to ensure long-term price stability. Further development of our capacity to conduct monetary policy will be critical to managing the expansion of the banking system, including interbank activity, as the economy expands and diversifies.

\section{To this end, the CBSI is formulating new regulations aimed at improving banks'} capacity at liquidity management and responsiveness to monetary operations. Over the program period, we will replace the current liquid asset requirement with a required reserve system, introduce new overnight facilities, and issue short-term bills. We will clarify lender of last resort provisions by issuing new central bank executive regulations by end-June 2010 and finalize an issuance plan for shorter maturity CBSI bills by end-December 2010, if necessary with further IMF technical assistance.

16. We will take necessary actions to maintain an adequate level of foreign reserves, in light of the Solomon Islands's vulnerability to shocks. Given recent improvements to the external position, pressure on the exchange rate has eased. While the exchange rate provides a measure of stability as a nominal anchor, greater exchange rate flexibility will be pursued, as necessary, to help achieve the program's target on net international reserves (NIR). In the event that NIR falls by more than US $\$ 15$ million during the previous 30 days, we will consult with IMF staff on the appropriate policy response.

\section{Financial Sector Issues}

17. We remain committed to maintaining a healthy financial system by strengthening CBSI oversight and implementing new prudential regulations. Despite the economic downturn, banks are currently well-capitalized and maintain adequate liquidity. However, we 
will continue to carefully monitor them in view of the recent deterioration in asset quality. We have implemented a new set of regulations aimed at strengthening the prudential requirements for commercial banks and other depository corporations, which, with technical assistance, will be extended to other financial corporations. These regulations have tightened requirements on capital adequacy, asset classification, and loan loss provisioning. The CBSI will also begin publishing financial soundness indicators.

18. As the country's primary savings vehicle, we intend to strengthen oversight of the National Provident Fund (NPF) and better protect the independence of its operations. With further technical assistance, we will submit a revised NPF Act to Cabinet by end-2010 clarifying the CBSI's supervisory responsibilities, the provident fund's investment mandate, and its obligations to member contributors to safeguard long-term financial viability. We will ensure any social role envisaged for the NPF does not undermine the sound management of its assets.

\section{OTHER ISSUES}

19. External debt and arrears: We continue to implement the action plan of the Honiara Club Agreement with its signatories. Going forward, our debt management strategy will be consistent with maintaining a low level of external and public indebtedness. External arrears have been resolved with private creditors. Outstanding arrears with official creditors, now exclusively with the European Investment Bank (US\$3 million) will be cleared this year.

20. Safeguards Assessments: We agree to ensure completion of the IMF's safeguards assessment by the time of the first review of the SCF Arrangement. The CBSI will provide Fund staff with all necessary information for the assessment.

21. Statistical issues: We recognize that macroeconomic statistics require further strengthening in order to establish well defined targets and objectives and ultimately to monitor outcomes and performance. Our priorities remain to strengthen the reporting of government finance statistics, in view of the public sector's size relative the rest of the economy, and compilation of national income accounts, to develop a purposeful measure of basic economic performance.

22. Technical assistance: We have identified a number of technical assistance and capacity building needs that are critical for our reform agenda, where we will look for the IMF and other development partners for continued support. Envisaged IMF technical assistance, including from the Pacific Financial and Technical Assistance Center, would focus on (i) further strengthening monetary management and prudential requirements; (ii) assessing revenue policy and developing a resource tax regime; (iii) supporting public financial management reforms, including through contributing to the PER, and entrenching fiscal responsibility into our legal framework; and (v) improving data compilation and reporting in key statistical areas. 
Table 1. Solomon Islands: Quantitative Performance Criteria (PC) and Indicative Targets (IT)

\begin{tabular}{|c|c|c|c|c|c|}
\hline & $\begin{array}{c}12 / 31 / 2009 \\
\text { Est. }\end{array}$ & $\frac{6 / 30 / 2010}{P C}$ & $\begin{array}{c}9 / 30 / 2010 \\
\text { IT }\end{array}$ & $\frac{12 / 31 / 2010}{P C}$ & $\frac{3 / 31 / 2011}{\text { IT }}$ \\
\hline \multicolumn{6}{|l|}{ Performance criteria 1/ } \\
\hline $\begin{array}{l}\text { Net international reserves (NIR) of the Central Bank of } \\
\text { Solomon Islands (CBSI) (floor, eop stock, in millions of } \\
\text { U.S. dollars (US\$)) 2/ }\end{array}$ & 146 & 147 & 141 & 158 & 160 \\
\hline $\begin{array}{l}\text { Net domestic asset (NDA) of the CBSI (ceiling, eop stock, } \\
\text { in millions of Solomon Islands dollars }(\mathrm{SI} \$) \text { ) 3/ }\end{array}$ & -367 & -332 & -327 & -472 & -447 \\
\hline $\begin{array}{l}\text { Net credit to central government (NCG) (ceiling, cumulative } \\
\text { change from the beginning of the year, in millions of SI\$) 4/ }\end{array}$ & -77 & 40 & 22 & -102 & 31 \\
\hline $\begin{array}{l}\text { New nonconcessional external debt maturing in more than } \\
\text { one year, contracted or guaranteed by the public sector } \\
\text { (ceiling, eop stock since the beginning of the program, in } \\
\text { millions of US\$) 5/ }\end{array}$ & $\ldots$ & 0 & 0 & 0 & 0 \\
\hline $\begin{array}{l}\text { New nonconcessional external debt maturing in one year } \\
\text { or less, contracted or guaranteed by the public sector } \\
\text { (ceiling, eop stock since the beginning of the program, in } \\
\text { millions of US\$) 5/ }\end{array}$ & $\ldots$ & 0 & 0 & 0 & 0 \\
\hline $\begin{array}{l}\text { Accumulation of new external payment arrears by the } \\
\text { public sector (ceiling, eop stock since the beginning of the } \\
\text { program, in millions of SI\$) } 5 \text { / }\end{array}$ & $\ldots$ & 0 & 0 & 0 & 0 \\
\hline $\begin{array}{l}\text { Central government program cash balance (floor, } \\
\text { cumulative change from the beginning of the year, in } \\
\text { millions of SI\$) } 4 \text { / }\end{array}$ & $\ldots$ & -37 & -13 & 120 & -33 \\
\hline $\begin{array}{l}\text { Memorandum item: } \\
\text { Budget support from bilateral and multilateral donors other } \\
\text { than IMF (cumulative change from the beginning of the } \\
\text { year, in millions of US\$), program level. }\end{array}$ & 28 & 17 & 24 & 53 & 8 \\
\hline
\end{tabular}

1/ Evaluated at the program exchange rate.

2/ The adjustors are specified in the Technical Memorandum of Understanding (TMU) and include: the floor on NIR will be adjusted upward (downward) by the amount of budget support from bilateral and multilateral donors (excluding IMF) in excess (short) of the program level.

3/ The adjustors are specified in the TMU and include: the ceilings on NDA will be adjusted downward (upward) by the amount of budget support from bilateral and multilateral donors (excluding the IMF) in excess (short) of the program level.

4/ The adjustors are specified in the TMU and include: the floor on central government program cash balance will be adjusted downward and the ceiling on NCG will be adjusted upward by the amount of budget support from bilateral and multilateral donors (excluding the IMF) short of the program level.

5/ These performance criteria are applicable on a continuous basis. 
Table 2. Solomon Islands: Prior Actions and Structural Benchmarks

\begin{tabular}{lccc}
\hline Actions & Date & Macroeconomic criticality \\
\hline
\end{tabular}

\section{Prior Actions}

Develop a rolling three-month forward cash forecast for the government's recurrent and development budget.

Withdraw spending warrants equivalent to at least SI\$116 million.

Issue a ministerial circular indicating contingency warrants in 2010 will be fully funded by line-item adjustments to ministerial appropriations and/or new revenue measures.

\section{Structural Benchmarks}

Apply full enforcement actions to collect income tax arrears.

Issue a ministerial circular authorizing annual notification to the Public Accounts Committee of the nature and cost of all tax and customs exemptions granted.

Issue monetary policy regulations revising the lender of last resort provisions of the Central Bank of Solomon Islands (CBSI).

Adopt an automatic adjustment mechanism for the price of logs, with the determined price adjusted to no less than 85 percent of the formula-based price from October 1, 2010, and a quarterly phase-in thereafter to achieve full consistency with the formula-based price from July 1, 2011.

Amend the Customs Valuation Act and issue new implementation guidelines by end2010, bringing the act into full effect.

Submit to Parliament a set of amendments to the Customs and Excise and Income Tax Acts legalizing exemption criteria and guidelines, including full disclosure requirements, and merging existing exemption committees into a unified committee structure.

Incorporate all line ministries and employees into the new payroll accounting system.

Finalize an issuance plan for CBSI bills.

Submission to the Cabinet of a revised National Provident Fund Act strengthening independence and oversight.

Formulate a resource tax regime, consistent with IMF technical assistance recommendations.

Draft fiscal responsibility provisions to be incorporated into either a Fiscal Responsibility Act or an amended Public Finance and Audit Act.

To strengthen budget execution and fiscal mangement.

To normilize fiscal operations and achieve fiscal targets.

To avoid spending overruns and achieve fiscal targets.

Continuous

June 30,2010

June 30,2010

September 30, 2010

December 31, 2010

December 31, 2010

December 31, 2010

December 31, 2010

December 31, 2010

June 30, 2011

June 30, 2011

\section{To strengthen revenue administration and collections.}

To promote fiscal transparency and enhance revenue collections.

To safeguard the stability of the financial sector.

To promote fiscal transparency, enhance revenue collections, and ensure sustained output.

To strengthen customs administration and revenue collections.

o promote fiscal transparency and enhance the efficiency of revenue collections.

To strengthen expenditure oversight and control.

To broaden monetary instruments.

To improve the long-term financial viability and reduce fiscal risks.

To broaden the tax base and increase revenue transparency.

To strengthen budget management and ensure fiscal sustainability. 


\section{SOLOMON ISLANDS—TECHNICAL MEMORANDUM OF UNDERSTANDING}

1. The program will be monitored through quantitative performance criteria, indicative targets, structural benchmarks, and reviews. This memorandum sets out the definitions for quantitative performance criteria and indicative targets under which performance under the program will be assessed. Monitoring procedures and reporting requirements are also specified.

\section{Quantitative Performance Criteria ANd Indicative Targets}

2. Performance criteria for end-June 2010 and end-December 2010 and indicative targets for end-September 2010, and end-March 2011 have been established with respect to:

- Floors on the level of net international reserves (NIR) of the Central Bank of Solomon Islands (CBSI);

- $\quad$ Ceilings on the level of net domestic assets (NDA) of the CBSI;

- $\quad$ Ceilings on the level of net credit to the central government (NCG);

- $\quad$ Floors on the central government cash balance.

3. Performance criteria applicable on a continuous basis have been established with respect to:

- $\quad$ Ceilings on the contracting and guaranteeing by the public sector of new medium- and long-term nonconcessional external debt;

- $\quad$ Ceilings on the contracting and guaranteeing by the public sector of new short-term nonconcessional external debt;

- $\quad$ Ceilings on accumulation of new external payment arrears by the public sector.

\section{InSTITUTIONAL DEFINITIONS}

4. The central government includes all units of budgetary central government and extrabudgetary funds.

5. Depository corporations (DCs) include the CBSI and other depository corporations (ODCs). ODCs include commercial banks, the Credit Corporation of Solomon Islands, and credit unions. Financial corporations include DCs and other financial corporations (OFCs). OFCs are the National Provident Fund (NPF), the Development Bank of Solomon Islands, and the Investment Corporation of Solomon Islands. 


\section{Monetary Aggregates}

6. Valuation. Foreign currency-denominated accounts will be valued in Solomon Islands dollar (SI\$) at the program exchange rate of SI\$8.06 per U.S. dollar, as of end-2009. Foreign currency accounts denominated in currencies other than the U.S. dollar and monetary gold will first be valued in U.S. dollars at actual exchange rates and gold prices used by the CBSI, respectively, before they are converted to Solomon Island dollars.

\section{A. Reserve Money}

7. Reserve money consists of currency issued by the CBSI (excluding CBSI holdings of currency) and all transferable deposits held at the CBSI.

\section{B. Net International Reserves of the CBSI}

8. A floor applies to the level of NIR of the CBSI. The floor on NIR will be adjusted upward (downward) by the amount of budget support from bilateral and multilateral donors (excluding IMF) in excess (short) of the programmed level.

9. NIR will be calculated as gross international reserves (GIR) less international reserve liabilities. For program monitoring purposes, the stock of foreign assets and foreign liabilities of the CBSI, as reported in Solomon Islands dollars, shall be valued at program exchange rate in U.S. dollars, as described on paragraph 6.

10. GIR of the CBSI are defined as the sum of:

- $\quad$ Foreign currency assets in convertible currencies held abroad and as vault cash that are under the direct and effective control of the CBSI and readily available for intervention in the foreign exchange market or the direct financing of balance of payments imbalances and are of investment grade or held with an investment-grade institution.

- $\quad$ The reserve position of the Solomon Islands in the IMF; and

- Holding of SDRs; and

- $\quad$ Monetary gold.

Excluded from the definition of GIR are:

- $\quad$ Foreign currency deposits of ODCs and OFCs held at the CBSI;

- $\quad$ Any foreign currency claims on residents, capital subscriptions in international institutions, and foreign currency assets in nonconvertible currencies, and; 
- $\quad$ GIR that are in any way encumbered or pledged, including, but not limited to, reserve assets used as collateral or guarantee for third-party external liabilities.

11. International reserve liabilities of the CBSI are defined as the sum of:

- $\quad$ All outstanding liabilities of the Solomon Islands to the IMF, excluding IMF SDR allocations; and

- $\quad$ Foreign currency liabilities in convertible currencies to nonresidents with an original maturity of up to and including one year

\section{Net Domestic Assets of the CBSI}

12. A ceiling applies to the level of NDA of the CBSI. The ceiling on NDA will be adjusted downward (upward) by the amount of budget support from bilateral and multilateral donors (excluding IMF) in excess (short) of the programmed level.

13. NDA of the CBSI will be calculated as the difference between reserve money and the sum of NIR of the CBSI and other NFA of the CBSI. Other NFA of the CBSI includes:

- $\quad$ Foreign assets related to holdings of foreign currency deposits, and securities not included in NIR of the CBSI, and loans, shares, financial derivatives, or accounts receivable with nonresidents; and other foreign assets that are not included in NIR of the CBSI, as defined in Section III. B; and

- $\quad$ Foreign liabilities related to IMF SDR allocations; deposits, securities, loans, financial derivatives, and other accounts payable with nonresidents; and other foreign liabilities that are not included in NIR of the CBSI, as defined in Section III. B.

\section{Net Credit to the Central Government}

14. A ceiling applies to the NCG measured cumulatively from the beginning of the year. The ceiling on NCG will be adjusted upward by the amount of budget support from bilateral and multilateral donors (excluding IMF) short of the programmed level.

15. NCG is defined as the sum of net claims of (i) the CBSI, (ii) commercial banks and other ODCs, and (iii) OFCs.

\section{Fiscal Aggregates}

\section{A. Cash Balance of the Central Governm3ent}

16. A floor applies to the program cash balance of the central government. The floor on the program cash balance will be adjusted downward by the amount of budget support from bilateral and multilateral donors (excluding IMF) in short of the programmed level. 
17. The program cash balance of the central government is defined as the gross cash balance minus the total amount of unpaid payment orders and unpresented checks.

18. The gross cash balance is defined as the sum of government deposits in the following accounts:

- In CBSI: Solomon Islands Government (SIG) Revenue Account, SIG Funded Development Account, SIG Debt Servicing Account;

- $\quad$ In Australia New Zealand Bank: SIG Creditors Account and Payroll Imprest Account;

- In Bank of South Pacific: Provincial Revenue Holding Account, SIG Inland Revenue Account, Sub Treasury Gizo Account, and Sub Treasury Auki Account; and,

- $\quad$ Other accounts that are created and under control of the government.

\section{EXTERNAL DEBT}

\section{A. Medium- and Long-Term External Debt}

19. A ceiling applies to the contracting and guaranteeing by the public sector of new nonconcessional borrowing with nonresidents with original maturities of more than one year. The ceiling applies to debt and commitments contracted or guaranteed for which value has not yet been received. This applies to private debt for which official guarantees have been extended and which, therefore, constitutes a contingent liability of the public sector. The public sector comprises the central government, the CBSI, nonfinancial public enterprises, and other official entities.

20. The definition of debt, for the purposes of the program, is set out in Point 9 of the Guidelines on Performance Criteria with Respect to External Debt in Fund Arrangement Executive Board Decision No. 6230-(79/140), as revised on August 31, 2009 (see Annex I).

21. Excluded from the ceiling are (i) the use of Fund resources; (ii) lending from the World Bank and the Asian Development Bank; (iii) debts incurred to restructure, refinance, or prepay existing debts, to the extent that such debt is incurred on more favorable terms than the existing debt and up to the amount of the actually restructured/refinanced/prepaid debt; (iv) concessional debts; (v) any SI\$-denominated treasury bill and bond holdings and Bokolo bonds held by nonresidents.

22. For program purposes, the guarantee of a debt arises from any explicit legal obligation of the central government, the CBSI, nonfinancial public enterprises, or other official entities on behalf of the central government or the CBSI to service debt in the event of nonpayment by the main obligor (involving payments in cash or in kind). 
23. For program purposes, a debt is concessional if it includes a grant element of at least 35 percent, calculated as follows: the grant element of a debt is the difference between the net present value (NPV) of debt and its nominal value, expressed as a percentage of the nominal value of the debt. The NPV of debt at the time of its contracting is calculated by discounting the future stream of payments of debt service due on this debt. The discount rates used for this purpose are the currency specific commercial interest reference rates (CIRRs), published by the Organization for Economic Cooperation Development (OECD). For debt with a maturity of at least 15 years, the ten-year-average CIRR will be used to calculate the NPV of debt and, hence, its grant element. For debt with a maturity of less than 15 years, the six-month average CIRR will be used. To both the ten-year and six-month averages, the same margins for differing repayment periods as those used by the OECD would continue to be added ( 0.75 percent for repayment periods of less than 15 years, 1 percent for 15 to 19 years, 1.15 percent for 20 to 29 years, and 1.25 percent for 30 years or more).

\section{B. Short-Term External Debt}

24. A ceiling applies to the contracting and guaranteeing by the public sector of new nonconcessional borrowing with nonresidents with original maturities of up to and including one year. The ceiling applies to debt and commitments contracted or guaranteed for which value has not yet been received. This applies to private debt for which official guarantees have been extended and which, therefore, constitute a contingent liability of the public sector.

25. For program purposes, the definition of debt is set out in Point 9 of the Guidelines on Performance Criteria with Respect to External Debt in Fund Arrangement approved by the Executive Board Decision No. 6230-(79/140), as revised on August 31, 2009 (see Annex I).

26. Excluded from the ceiling are (i) debts classified as international reserve liabilities of the CBSI; (ii) debts incurred to restructure, refinance, or prepay existing debts, to the extent that such debt is incurred on more favorable terms than the existing debt and up to the amount of the actually restructured/refinanced/prepaid debt; (iii) SI\$-denominated treasury bills and bonds and CBSI and Bokolo bills held by nonresidents; and (iv) normal import financing. A financing arrangement for imports is considered to be "normal" when the credit is selfliquidating.

\section{External Payment Arrears}

27. A continuous performance criterion applies to the nonaccumulation of external payments arrears by the public sector, comprising the central government, the CBSI, nonfinancial public enterprises, and other official entities. External payments arrears consist of external debt-service obligations (principal and interest) that have not been paid at the time they are due, as specified in the contractual agreements. 
VII. DAta Provision

28. The data listed below will be provided for monitoring performance under the program based on data templates agreed with Fund staff. Under each section, reporting responsibilities are indicated in parentheses. Weekly data are requested for submission to Fund staff by the end of the following week. Monthly and quarterly data are requested for submission within six weeks of the end of the observation period. The authorities have committed to using the best available data, so that any subsequent data revisions will not lead to a breach of quantitative performance criteria or benchmarks. All revisions to data will be promptly reported to Fund staff.

On a weekly basis:

\section{A. Monetary Data (CBSI)}

- Daily exchange rates, both buying and selling rates, of the Solomon Islands dollar against the U.S. dollar, including the official, interbank, and parallel market exchange rates.

- $\quad$ Stock of NIR and sales and purchases by the CBSI in the foreign exchange markets.

- $\quad$ Stock of reserve money and its components.

On a monthly basis:

- $\quad$ Financial corporations' survey, including the balance sheet of CBSI, the consolidated balance sheet of ODCs, and the consolidated balance sheet of OFCs.

- $\quad$ Liquid asset ratios of the commercial banks.

- Interest rates, including average interbank rate, bank deposit rates, and bank lending rates.

- A detailed breakdown of NCG from the CBSI, commercial banks and other ODCs, and OFCs.

- $\quad$ Foreign exchange cash-flow of the CBSI, including donor disbursements.

- Balances of each central government account specified in Section IV. A., as recorded or collected by the CBSI.

\section{B. Fiscal Data (Ministry of Finance and Treasury (MoFT))}

On a monthly basis:

- Consolidated accounts of the central government, including detailed data on: 
- $\quad$ Revenue, including tax and nontax revenues, and recurrent and development grants included in the consolidated budget.

- $\quad$ Recurrent expenditure, including payroll, goods and services, and other recurrent outlays, including those funded by donor support.

- Debt service payments, classified into amortization and interest payments on (i) domestic debt, (i) external debt, (iii) domestic arrears, and (iv) external arrears.

- $\quad$ Development expenditure funded by (i) central government of the Solomon Islands, and (ii) foreign grants and loans included in the consolidated budget.

- Detailed financing components of central government's accounts, classified into foreign and domestic sources.

- $\quad$ Foreign financing includes (i) disbursement and amortization of project and program loans, and (ii) changes in external debt arrears, classified into principal and interest arrears.

- $\quad$ Domestic financing includes (i) borrowing from and repayment to the CBSI commercial banks and other ODCs, and OFCs; (ii) changes in deposits withdrawal from commercial banks, commercial banks and other ODCs, and OFCs; and (iii) privatization receipts and changes in domestic debt arrears, classified into principal and interest arrears.

- $\quad$ Stock of domestic debt, including the outstanding balance of government securities, treasury bills, cash advances, and other debt instruments.

- $\quad$ Balances of each central government account specified in Section IV. A., as recorded by the MoFT.

- $\quad$ Stock of unpaid government payment orders and unpresented checks.

\section{External Sector Data (CBSI and MoFT)}

On a quarterly basis:

- New external debt obligations contracted and/or guaranteed by the government of the Solomon Islands, CBSI, and other official entities, including details on the amounts, terms, and conditions of each obligation.

- $\quad$ Stock of outstanding external debt at end-month and disbursement, amortization, and interest payments for short-term external obligations contracted or guaranteed by the government or the CBSI by creditor in original currency and U.S. dollars. 
- $\quad$ Stock of external debt at end-month and disbursement, amortization, and interest payments for medium- and long-term external obligations contracted or guaranteed by the government or the CBSI by creditor in original currency and U.S. dollars.

- $\quad$ Stock of arrears on the external debt contracted or guaranteed by the government or the CBSI by creditor in original currency and in U.S. dollars at end-month.

On a quarterly basis:

- $\quad$ Balance of payment data, including detailed components of current accounts and capital and financial accounts.

\section{Real Sector Data (MoFT, National Statistical Office)}

On a monthly basis:

- The monthly consumer price index and a detailed breakdown by major categories of goods and services included in the consumer basket. 


\section{Annex I. Guidelines on Performance Criteria with Respect to Foreign Debt}

Excerpt from Executive Board Decision No. 6230-(79/140), as revised on August 31, 2009

9. (a) For the purpose of this guideline, the term "debt" will be understood to mean a current, i.e., not contingent, liability, created under a contractual arrangement through the provision of value in the form of assets (including currency) or services, and which requires the obligor to make one or more payments in the form of assets (including currency) or services, at some future point(s) in time; these payments will discharge the principal and/or interest liabilities incurred under the contract. Debts can take a number of forms, the primary ones being as follows:

(i) loans, i.e., advances of money to the obligor by the lender made on the basis of an undertaking that the obligor will repay the funds in the future (including deposits, bonds, debentures, commercial loans and buyers' credits) and temporary exchanges of assets that are equivalent to fully collateralized loans under which the obligor is required to repay the funds, and usually pay interest, by repurchasing the collateral from the buyer in the future (such as repurchase agreements and official swap arrangements);

(ii) suppliers' credits, i.e., contracts where the supplier permits the obligor to defer payments until sometime after the date on which the goods are delivered or services are provided; and

(iii) leases, i.e., arrangements under which property is provided which the lessee has the right to use for one or more specified period(s) of time that are usually shorter than the total expected service life of the property, while the lessor retains the title to the property. For the purpose of the guideline, the debt is the present value (at the inception of the lease) of all lease payments expected to be made during the period of the agreement excluding those payments that cover the operation, repair or maintenance of the property.

(b) Under the definition of debt set out in point 9 (a) above, arrears, penalties, and judicially awarded damages arising from the failure to make payment under a contractual obligation that constitutes debt are debt. Failure to make payment on an obligation that is not considered debt under this definition (e.g., payment on delivery) will not give rise to debt. 


\section{APPENDIX II. Solomon Islands: Debt Sustainability Analysis Update ${ }^{1}$}

This update of the Debt Sustainability Analysis (DSA) for the Solomon Islands incorporates the prospective disbursements under a Standby Credit Facility (SCF) arrangement with the IMF and the latest available debt data at end-2009. The results indicate that the impact of the SCF on debt sustainability should be minimal. The policies envisaged under a Fund-supported program would lead to a stronger fiscal position in the medium term, resulting in a generally lower level of public debt in the long run. The results of this DSA update are broadly in line with those of previous DSA, with the Solomon Islands facing a medium risk of debt distress.

\section{BACKGROUND}

\section{At end-2009, total public debt stock was around 28 percent of GDP (around} US\$185 million), including credit guarantees and arrears. The stock of debt differs slightly from those in the previous DSA mainly as a result of debt data provided by the Solomon Islands authorities to end-2009. Almost three-quarters of public debt is external debt, while domestic public debt is mostly in the form of restructured bonds owed to the banking sector, including the Central Bank of Solomon Islands (CBSI).

\section{Total public external debt amounted to US\$133 million or 20 percent of GDP at} end-2009. Main creditors are the Asian Development Bank (AsDB) and the World Bank Group's International Development Association (IDA), with their shares of total public external debt around 40 percent and 30 percent, respectively. Other external creditors include the European Commission, European Investment Bank, International Fund for Agriculture Development, and Organization of the Petroleum Exporting Countries.

Solomon Islands: Public and Publicly Guaranteed (PPG) Debt $\mathbf{1 /}$

\begin{tabular}{|c|c|c|c|c|c|c|c|c|}
\hline & \multirow[b]{2}{*}{$2008^{-}$} & \multicolumn{2}{|l|}{ Est. } & \multicolumn{4}{|c|}{ Proj. } & \multirow[b]{2}{*}{2015} \\
\hline & & 2009 & 2010 & 2011 & 2012 & 2013 & 2014 & \\
\hline External debt in US\$ million & 144 & 133 & 133 & 136 & 133 & 133 & 134 & 135 \\
\hline In percent of GDP & 23.0 & 20.2 & 20.2 & 19.7 & 17.5 & 15.7 & 14.2 & 12.5 \\
\hline Domestic debt in SI\$ million & 457 & 425 & 372 & 316 & 272 & 229 & 187 & 149 \\
\hline In percent of GDP & 9.1 & 8.0 & 6.7 & 5.2 & 3.9 & 2.9 & 2.0 & 1.4 \\
\hline Total debt in percent of GDP & 32.1 & 28.3 & 26.8 & 24.9 & 21.4 & 18.5 & 16.3 & 13.9 \\
\hline Of which: Prospective Fund credit & 0.0 & 0.0 & 1.4 & 2.7 & 2.5 & 2.2 & 1.8 & 1.3 \\
\hline
\end{tabular}

Sources: The Solomon Islands authorities; and Fund staff estimates

$1 /$ Includes prospective disbursements under Fund arrangement

\footnotetext{
${ }^{1}$ This document is an update to the joint World Bank/IMF DSA prepared during the 2009 Article IV Consultation with the Solomon Islands (see IMF Country Report No. 09/309).
} 


\section{Main Assumptions}

3. Under the prospective IMF-supported program, the policies agreed are expected to improve medium-term prospects for macroeconomic stability and debt sustainability. The fiscal position is projected to be stronger than that assumed under the previous DSA, while other assumptions are expected to remain broadly the same.

- $\quad$ Real GDP growth is projected to rebound from minus $2 \frac{1}{4}$ percent in 2009 to around $3 \frac{1}{2}$ percent in 2010 and 51/4 percent in 2011. Starting in 2012, annual growth is expected to increase substantially compared to the historical average, mainly because of planned production of gold starting in 2012 and nickel in 2015. Foreign direct investment (FDI), mainly to develop mines, is also expected to pick up substantially in the near to medium term. GDP growth during 2015-19 is slightly higher than in the previous DSA due to a moderate upward revision in projected volume of gold production. Inflation is expected to be 5-6 percent a year during 2010-14 assuming sound macroeconomic policies and stable international commodity prices.

- The overall fiscal position in the medium term is projected to improve compared with that assumed in the previous DSA. Under the Fund-supported program, the government expects to run an overall fiscal surplus in 2010 and 2011 of $2-2 \frac{1}{2}$ percent of GDP a year, reflecting its efforts to build up cash reserves and strengthen overall fiscal operations. To ensure the Solomon Islands stays on a sustainable fiscal path and taking into account the government's limited capacity to borrow at home or abroad, the government is expected to continue running fiscal surpluses in 2012-14 averaging about $13 / 4$ percent of GDP a year. Government expenditure is expected to decline (as a share of GDP) over the long run, largely in line with a projected scaling back in project grants for technical and security support. In the event, the overall fiscal balance (including grants) would turn from a small surplus to a small deficit in the long run, financed mostly through external borrowing (discussed below).

- The current account deficit is expected to remain large over the near to medium term because of a rapid decline in logging exports and large imports related to mining development (financed mostly by FDI). Under the current baseline, gold exports will commence in 2012 and nickel exports in 2015, providing a major boost to export earnings. Over the long term, the deficit would gradually narrow and then stabilize at about $3 \frac{1}{2}$ percent to GDP. The stock of gross international reserves in the long run would be slightly higher than in the previous DSA mainly due to a moderate upward revision in projected mineral exports. 
- $\quad$ External borrowing: In line with the assumptions made in the 2009 DSA and in the spirit of the Honiara Club Agreement (HCA) ${ }^{2}$, the baseline scenario assumes the government maintains its policy of no new borrowing in the near term. Starting in 2012, modest concessional borrowing for development expenditure is expected to resume, responding to needs to improve basic infrastructure and given the expected falloff in external grants.

\begin{tabular}{|c|c|c|c|c|c|c|}
\hline \multicolumn{7}{|c|}{ Solomon Islands: Social Economic Indicators, 2008-29 } \\
\hline & \multirow[b]{2}{*}{2008} & \multicolumn{2}{|l|}{ Est. } & \multicolumn{2}{|c|}{ Proj. } & \multirow[b]{2}{*}{2029} \\
\hline & & 2009 & $2010-14$ & $2015-19$ & $2020-29$ & \\
\hline \multicolumn{7}{|l|}{ Growth and prices (percentage change) } \\
\hline Real GDP & 7.3 & -2.2 & 6.7 & 7.2 & 5.5 & 5.1 \\
\hline Of which: Nontimber and nonmining & 7.3 & 0.7 & 5.7 & 5.8 & 5.1 & 5.0 \\
\hline CPI (period average) & 17.4 & 7.1 & 5.3 & 5.1 & 5.0 & 4.9 \\
\hline (End of period) & 18.1 & 1.8 & 5.8 & 5.0 & 5.0 & 5.0 \\
\hline Per capita GDP (in US\$) & 1,274 & 1,268 & 1,430 & 2,175 & 3,551 & 4,397 \\
\hline Per capita GNI (in US\$) & 1,088 & 927 & 1,139 & 1,918 & 3,304 & 4,153 \\
\hline \multicolumn{7}{|l|}{ Central government operations (percent of GDP) } \\
\hline Total revenue and grants & 45.2 & 45.3 & 48.9 & 40.9 & 35.4 & 33.9 \\
\hline Recurrent revenue & 27.3 & 27.1 & 29.9 & 32.0 & 32.6 & 32.5 \\
\hline Grants & 17.9 & 18.2 & 19.0 & 8.9 & 2.8 & 1.4 \\
\hline Total expenditure & 45.5 & 43.1 & 47.0 & 40.1 & 36.2 & 34.9 \\
\hline Overall balance & -0.3 & 2.2 & 2.0 & 0.8 & -0.8 & -1.0 \\
\hline \multicolumn{7}{|l|}{ Balance of payments } \\
\hline Current account (balance (- deficit) & -106.1 & -138.7 & -216.6 & -249.5 & -81.5 & -121.0 \\
\hline (Percent of GDP) & -16.4 & -21.1 & -27.1 & -20.1 & -3.2 & -3.5 \\
\hline Gross official reserves (US\$ millions, end of period) & 89.5 & 146.0 & 224.4 & 675.4 & 656.4 & 409.3 \\
\hline (in months of next year's imports of GNFS) & 3.5 & 4.2 & 4.9 & 10.8 & 7.0 & 3.2 \\
\hline
\end{tabular}

Sources: Data provided by the authorities; and IMF staff estimates and projections.

\section{EXTERnAL DebT SustainabiLity}

\section{Baseline scenario}

4. Under the baseline, all external debt indicators remain below the indicative debt burden thresholds. In addition to the envisaged disbursements from the IMF in 2010-11, other external borrowing is assumed from 2012 (Table 1a).

5. The impact of prospective borrowing from the IMF on the Solomon Islands' debt sustainability is expected to be minimal. Total access under the SCF arrangement would amount to SDR 12.48 million (US\$19.5 million), or 120 percent quota, to be disbursed in 2010-11. These planned disbursements would increase the debt-to-GDP ratio by about $23 / 4$ percentage points by 2011 before declining gradually in the medium term. The impact of the SCF on debt service is also minimal, partly because disbursements under the SCF are interest free up to 2011. The debt service to the IMF at a maximum would be less than $1 / 2$ percent of GDP during 2014-16 and decline thereafter. Outstanding credits from the IMF would be expected to be fully repaid by 2020 .

\footnotetext{
${ }^{2}$ External borrowing has been restricted since 2005 under the terms of the Honiara Club Agreement (HCA), which was signed by the government and four major external creditors. Under the agreement, the Solomon Islands is expected to pursue grants and other overseas development assistance until it receives a "green light" rating from the World Bank's International Development Association.
} 


\section{Stress tests and alternative scenario}

6. Several thresholds are breached under the historical scenario and a few stress tests, similar to the results of the previous DSA.

- Under the historical scenario, the present values (PVs) of the debt-to-GDP ratio and debt-to-exports ratio exceed the thresholds. Two bound tests indicate significant increases in debt burden indicators - the shock to net nondebt creating flows and the combined shock to these flows, growth, exports, and deflators (Figure 1 and Table 1b). The results are sensitive to the nondebt creating flows partly because past foreign investment was lower than the current level, implying that a stress test based on the historical level of investment would lead to large debt creation.

- Under most scenarios and stress tests, debt service-to-exports ratio and debt service-torevenue ratio indicators would stay below the policy-dependent thresholds, supported by the relatively high concessionality of public external borrowing.

\section{An alternative scenario is also examined to demonstrate the potential volatility of} the Solomon Islands' debt sustainability. This scenario assumes that gold exports are delayed until 2014 and nickel exports do not materialize due to volatile commodity prices, land tenure issues, and financing constraints. Similar to the results of previous DSA, lower GDP growth, smaller export earnings, and larger fiscal deficits would be expected to materialize. However, under this scenario, external debt would not necessarily rise, as the government's capacity to borrow abroad would be constrained by its weaker underlying fiscal position. In the event, it might seek recourse to more domestic borrowing, potentially crowding out the private sector credit and further dampening growth prospects (Table 3a).

\section{Public Debt Sustainability}

\section{Baseline scenario}

8. Total public debt is expected to decline steadily over the medium and long term. The stock of domestic public debt is expected to be lower than in the previous DSA, consistent with a stronger fiscal position expected under an IMF-supported program. However, some debt indicators would remain relatively high, such as the PV of the public sector debt-to-revenue ratio (excluding grants), which would stay above 40 percent through 2014 (Table 2a).

\section{Stress tests and alternative scenario}

\section{The results of the stress tests indicate that lower GDP growth would significantly} increase debt indicators, such as the PVs of the public sector debt-to-GDP ratio and debt-torevenue ratio, particularly in the longer term (Figure 2, Table 2b). The first bound test (a temporary but significant decline in GDP growth) corresponds to the most extreme shock, with this finding again pointing to the sensitivity of this DSA to growth conditions. Compared to the baseline, the alternative scenario leads to a larger built-up of domestic debt in the long run (Table 3b). 


\section{CONCLUSION}

10. The results of this DSA update are broadly in line with those of the previous DSA, with the Solomon Islands continuing to face a medium risk of debt distress. The impact on debt sustainability of IMF credits under the prospective SCF arrangement is expected to be minimal. No debt-distress thresholds are breached under the baseline and alternative scenarios. However, several thresholds are breached under the stress tests, indicating the vulnerability to shocks, in particular to net nondebt creating flows and GDP growth. 
Figure 1. Solomon Islands: Indicators of Public and Publicly Guaranteed External Debt under Alternatives Scenarios, 2009-29 1/
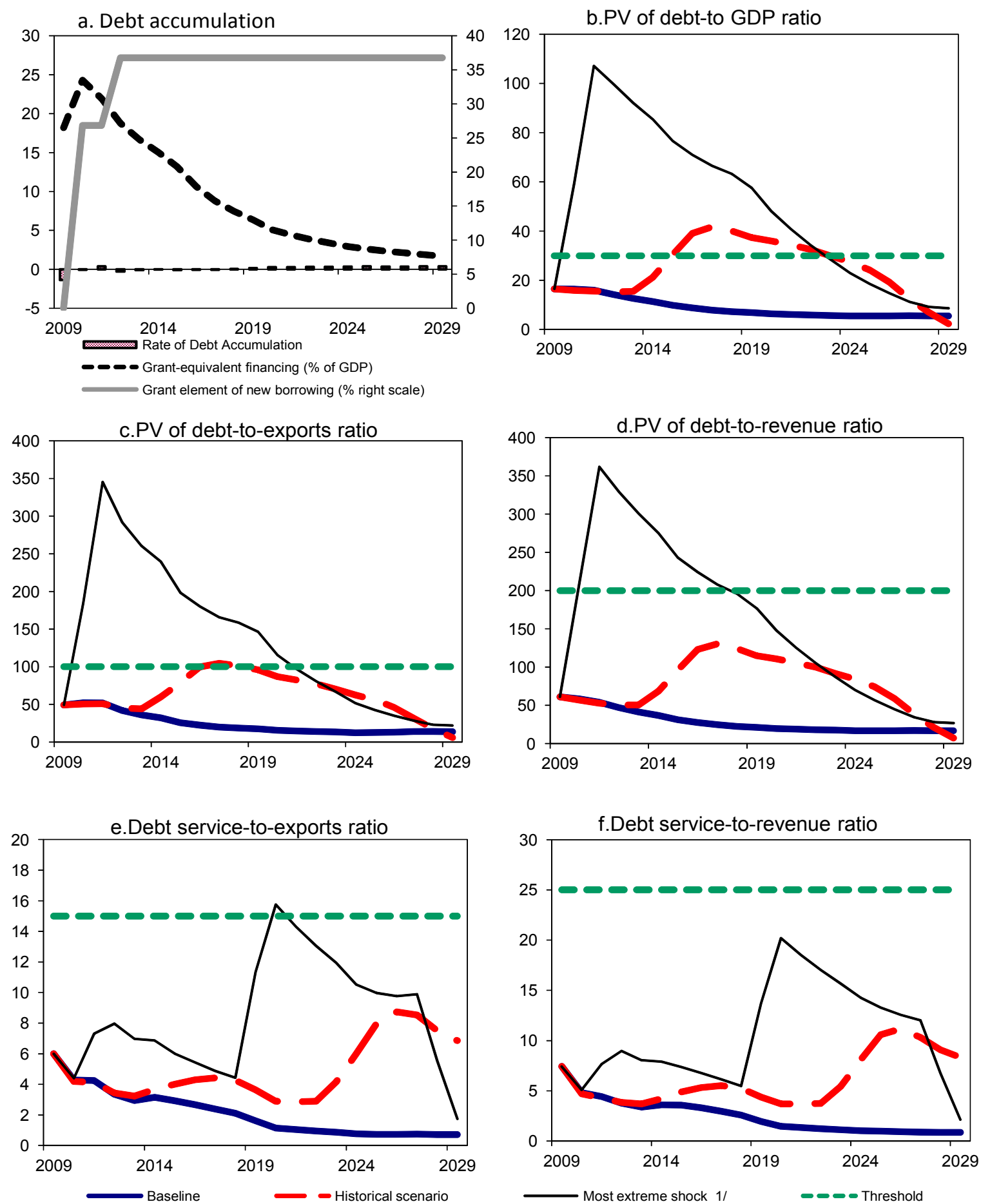

Sources: IMF staff estimates and projections.

1/ The most extreme stress test is the test that yields the highest ratio in 2019. In figure b. it corresponds to a Combination shock; in c. to a Combination shock; in d. to a Combination shock; in e. to a Combination shock and in figure f. to a Combination shock 
Figure 2.Solomon Islands: Indicators of Public Debt Under Alternative Scenarios, 2009-29 1/
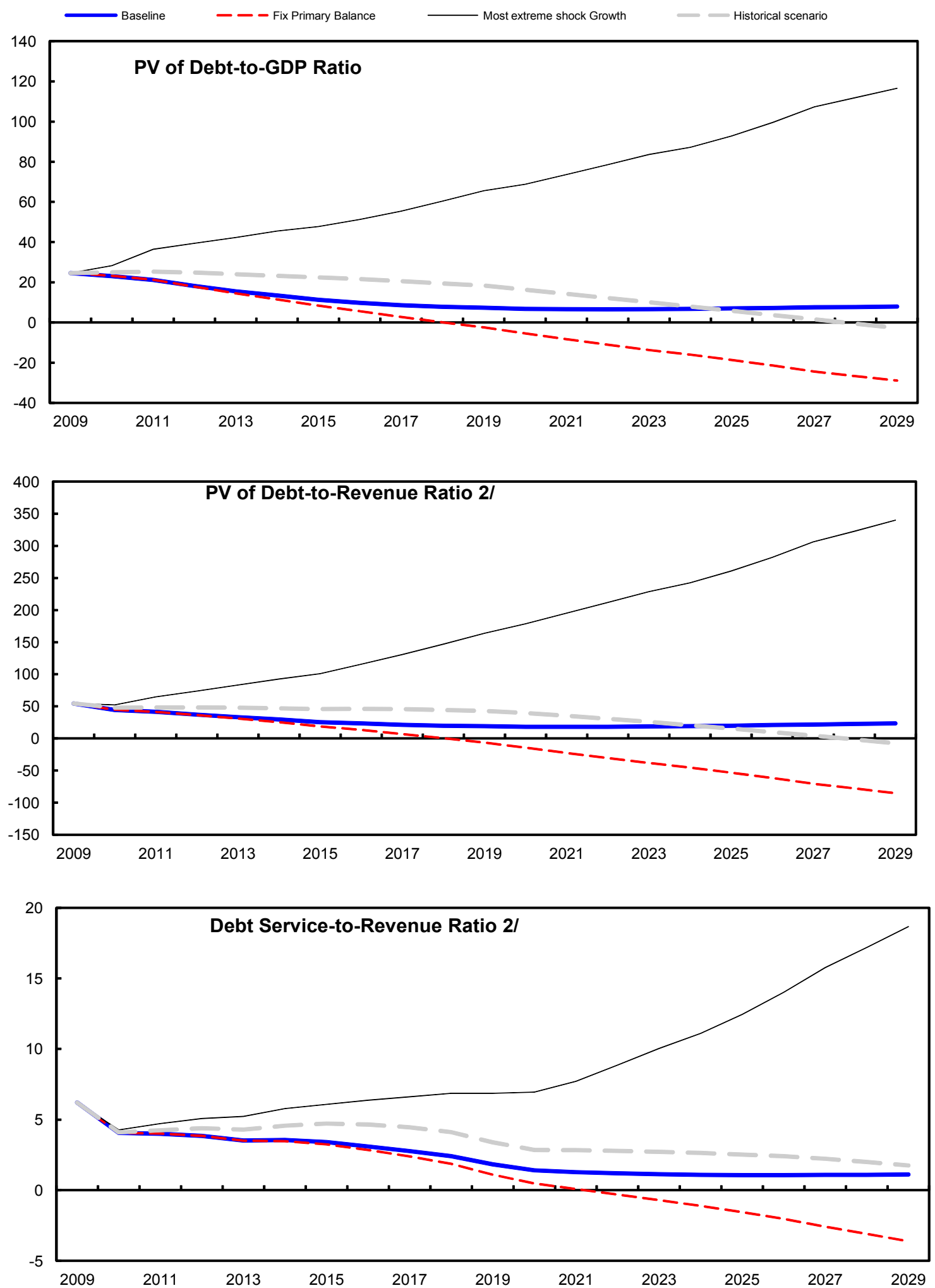

Sources: IMF staff estimates and projections.

$1 /$ The most extreme stress test is the test that yields the highest ratio in 2019.

2/ Revenues are defined inclusive of grants. 
Table 1a. Solomon Islands: External Debt Sustainability Framework, Baseline Scenario, 2006-29 1/

(In percent of GDP, unless otherwise indicated)

\begin{tabular}{|c|c|c|c|c|c|c|c|c|c|c|c|c|c|c|c|}
\hline & \multicolumn{3}{|c|}{ Actual } & \multirow{2}{*}{$\begin{array}{l}\text { Historical } \\
\text { Average }\end{array}$} & \multirow{2}{*}{$\begin{array}{c}16 \text { Standard } / 6 \\
\text { Deviation }\end{array}$} & \multicolumn{6}{|c|}{ Projections } & \multirow[b]{2}{*}{$\begin{array}{l}2009-14 \\
\text { Average }\end{array}$} & \multirow[b]{2}{*}{2019} & \multirow[b]{2}{*}{2029} & \multirow[b]{2}{*}{$\begin{array}{l}2015-29 \\
\text { Average }\end{array}$} \\
\hline & 2006 & 2007 & 2008 & & & 2009 & 2010 & 2011 & 2012 & 2013 & 2014 & & & & \\
\hline External debt (nominal) $1 /$ & 42.0 & 30.9 & 26.6 & & & 23.6 & 23.4 & 22.7 & 20.2 & 18.0 & 16.3 & & 10.9 & 8.9 & \\
\hline Of which: public and publicly guaranteed (PPG) & 36.6 & 26.8 & 23.0 & & & 20.2 & 20.2 & 19.7 & 17.5 & 15.7 & 14.2 & & 9.5 & 7.9 & \\
\hline Change in external debt & -2.8 & -11.1 & -4.3 & & & -2.9 & -0.2 & -0.7 & -2.5 & -2.2 & -1.7 & & -0.5 & -0.1 & \\
\hline Identified net debt-creating flows & -8.4 & -10.8 & 0.3 & & & 2.6 & -1.4 & -1.8 & -3.4 & -3.3 & -10.5 & & 1.3 & 2.0 & \\
\hline Noninterest current account deficit & 1.1 & 7.4 & 15.6 & 2.4 & 9.7 & 20.5 & 29.5 & 27.0 & 21.8 & 19.6 & 35.2 & & 6.3 & 3.4 & 8.6 \\
\hline Deficit in balance of goods and services & 17.4 & 19.7 & 20.5 & & & 13.4 & 30.7 & 28.3 & 22.1 & 19.3 & 35.0 & & 6.3 & 3.1 & \\
\hline Exports & 35.5 & 36.7 & 37.3 & & & 33.5 & 31.3 & 30.8 & 33.9 & 35.1 & 35.4 & & 39.0 & 39.4 & \\
\hline Imports & 52.9 & 56.4 & 57.8 & & & 46.9 & 62.0 & 59.1 & 56.0 & 54.4 & 70.4 & & 45.3 & 42.6 & \\
\hline Net current transfers (negative $=$ inflow) & -19.0 & -17.8 & -18.6 & -6.8 & 8.8 & -19.2 & -25.1 & -22.9 & -20.1 & -18.2 & -16.6 & & -8.9 & -5.1 & -7.9 \\
\hline Of which: official & -15.4 & -15.7 & -18.0 & & & -16.7 & -22.7 & -20.4 & -17.6 & -15.7 & -14.1 & & -6.3 & -2.0 & \\
\hline Other current account flows (negative $=$ net inflow) & 2.7 & 5.4 & 13.8 & & & 26.3 & 24.0 & 21.7 & 19.8 & 18.4 & 16.9 & & 8.9 & 5.4 & \\
\hline Net FDI (negative $=$ inflow) & -5.8 & -9.7 & -13.3 & -2.6 & 5.6 & -19.1 & -30.7 & -28.2 & -23.7 & -21.8 & -44.9 & & -4.7 & -1.1 & -10.0 \\
\hline Endogenous debt dynamics 21 & -3.7 & -8.5 & -2.1 & & & 1.2 & -0.2 & -0.7 & -1.5 & -1.1 & -0.8 & & -0.3 & -0.3 & \\
\hline Contribution from nominal interest rate & 0.5 & 0.8 & 0.8 & & & 0.6 & 0.6 & 0.5 & 0.5 & 0.4 & 0.4 & & 0.2 & 0.2 & \\
\hline Contribution from real GDP growth & -2.8 & -3.5 & -2.0 & & & 0.6 & -0.8 & -1.2 & -1.9 & -1.5 & -1.2 & & -0.6 & -0.4 & \\
\hline Contribution from price and exchange rate changes & -1.4 & -5.8 & -0.8 & & & & & & & & & & & & \\
\hline Residual (3-4) $3 /$ & 5.6 & -0.3 & -4.6 & & & -5.5 & 1.2 & 1.1 & 0.9 & 1.1 & 8.8 & & -1.8 & -2.1 & \\
\hline Of which: exceptional financing & 0.0 & 0.0 & 0.0 & & & 0.0 & 0.0 & 0.0 & 0.0 & 0.0 & 0.0 & & 0.0 & 0.0 & \\
\hline PV of external debt $4 /$ & $\ldots$ & $\ldots$ & 22.4 & & & 19.9 & 19.6 & 19.0 & 16.9 & 15.0 & 13.5 & & 8.3 & 6.5 & \\
\hline In percent of exports & $\ldots$ & $\ldots$ & 60.1 & & & 59.5 & 62.6 & 61.7 & 49.9 & 42.8 & 38.0 & & 21.4 & 16.6 & \\
\hline PV of PPG external debt & $\ldots$ & $\ldots$ & 18.8 & & & 16.6 & 16.4 & 16.0 & 14.3 & 12.7 & 11.4 & & 6.9 & 5.5 & \\
\hline In percent of exports & $\ldots$ & $\ldots$ & 50.4 & & & 49.4 & 52.3 & 51.9 & 42.0 & 36.2 & 32.1 & & 17.8 & 13.9 & \\
\hline In percent of government revenues & $\ldots$ & $\ldots$ & 68.9 & & & 61.1 & 58.7 & 54.0 & 47.0 & 41.5 & 36.7 & & 21.3 & 16.9 & \\
\hline Debt service-to-exports ratio (in percent) & 3.5 & 6.7 & 6.8 & & & 6.9 & 5.0 & 5.0 & 4.0 & 3.4 & 3.6 & & 1.9 & 0.9 & \\
\hline PPG debt service-to-exports ratio (in percent) & 2.5 & 5.8 & 5.9 & & & 6.0 & 4.3 & 4.2 & 3.4 & 2.9 & 3.1 & & 1.6 & 0.7 & \\
\hline PPG debt service-to-revenue ratio (in percent) & 3.8 & 8.6 & 8.1 & & & 7.4 & 4.8 & 4.4 & 3.8 & 3.4 & 3.6 & & 1.9 & 0.9 & \\
\hline Total gross financing need (billions of U.S. dollars) & 0.0 & 0.0 & 0.0 & & & 0.0 & 0.0 & 0.0 & 0.0 & 0.0 & -0.1 & & 0.0 & 0.1 & \\
\hline Noninterest current account deficit that stabilizes debt ratio & 3.9 & 18.5 & 20.0 & & & 23.4 & 29.7 & 27.8 & 24.3 & 21.8 & 37.0 & & 6.8 & 3.5 & \\
\hline Key macroeconomic assumptions & & & & & & & & & & & & & & & \\
\hline Real GDP growth (in percent) & 6.9 & 10.7 & 7.3 & 1.6 & 7.9 & -2.2 & 3.4 & 5.2 & 9.4 & 8.2 & 7.2 & 5.2 & 5.3 & 5.1 & 6.1 \\
\hline GDP deflator in U.S. dollar terms (change in percent) & 3.2 & 15.9 & 2.7 & 3.4 & 8.4 & 4.0 & -0.8 & -0.8 & 0.7 & 3.0 & 3.5 & 1.6 & 2.6 & 2.5 & 2.7 \\
\hline Effective interest rate (percent) $5 /$ & 1.4 & 2.4 & 2.8 & 2.1 & 1.2 & 2.4 & 2.4 & 2.3 & 2.2 & 2.2 & 2.2 & 2.3 & 2.2 & 2.0 & 2.1 \\
\hline Growth of exports of G\&S (U.S. dollar terms, in percent) & 16.9 & 32.5 & 12.0 & 5.9 & 25.4 & -8.5 & -4.2 & 2.6 & 21.5 & 15.3 & 12.0 & 6.4 & 6.3 & 7.5 & 9.8 \\
\hline Growth of imports of G\&S (U.S. dollar terms, in percent) & 39.4 & 36.8 & 12.9 & 10.4 & 30.2 & -17.3 & 35.5 & -0.6 & 4.6 & 8.2 & 43.7 & 12.3 & 5.0 & 4.9 & 5.6 \\
\hline Grant element of new public sector borrowing (in percent) & & & & $\ldots$ & $\ldots$ & 0.0 & 26.9 & 26.8 & 36.8 & 36.8 & 36.8 & 27.3 & 36.8 & 36.8 & 36.8 \\
\hline Government revenues (excluding grants, in percent of GDP) & 23.6 & 24.8 & 27.3 & & & 27.1 & 27.9 & 29.6 & 30.3 & 30.6 & 31.0 & & 32.5 & 32.5 & 32.4 \\
\hline Aid flows (in billions of U.S. dollars) $7 /$ & 0.1 & 0.1 & 0.1 & & & 0.1 & 0.2 & 0.2 & 0.1 & 0.1 & 0.1 & & 0.1 & 0.0 & \\
\hline Of which: Grants & 0.1 & 0.1 & 0.1 & & & 0.1 & 0.2 & 0.2 & 0.1 & 0.1 & 0.1 & & 0.1 & 0.0 & \\
\hline Of which: Concessional loans & 0.0 & 0.0 & 0.0 & & & 0.0 & 0.0 & 0.0 & 0.0 & 0.0 & 0.0 & & 0.0 & 0.0 & \\
\hline Grant-equivalent financing (in percent of GDP) 8/ & $\ldots$ & $\ldots$ & $\ldots$ & & & 18.2 & 24.3 & 22.0 & 18.8 & 16.7 & 15.1 & & 6.4 & 1.7 & 5.1 \\
\hline Grant-equivalent financing (in percent of external financing) $8 /$ & $\ldots$ & $\ldots$ & $\ldots$ & & & 100.0 & 95.9 & 95.6 & 98.3 & 97.4 & 96.0 & & 92.6 & 80.4 & 88.9 \\
\hline Memorandum items: & & & & & & & & & & & & & & & \\
\hline Nominal GDP (billions of U.S. dollars) & 0.5 & 0.6 & 0.6 & & & 0.7 & 0.7 & 0.7 & 0.8 & 0.9 & 1.0 & & 1.6 & 3.4 & \\
\hline Nominal dollar GDP growth & 10.3 & 28.3 & 10.2 & & & 1.8 & 2.5 & 4.4 & 10.2 & 11.5 & 11.0 & 6.9 & 8.0 & 7.7 & 8.9 \\
\hline PV of PPG external debt (in billions of U.S. dollars) & $\ldots$ & $\ldots$ & 0.1 & & & 0.1 & 0.1 & 0.1 & 0.1 & 0.1 & 0.1 & & 0.1 & 0.2 & \\
\hline (PVt-PVt-1)/GDPt-1 (in percent) & $\ldots$ & $\ldots$ & $\ldots$ & & & -1.4 & -0.1 & 0.4 & -0.3 & -0.1 & 0.0 & -0.3 & 0.2 & 0.4 & 0.2 \\
\hline
\end{tabular}

Sources: Solomon Island authorities; and IMF staff estimates and projections.

$1 /$ Includes both public and private sector external debt.

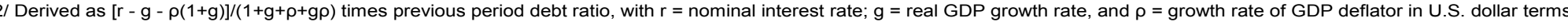

$3 /$ Includes exceptional financing (i.e., changes in arrears and debt relief); changes in gross foreign assets; and valuation adjustments. For projections also includes contribution from price and exchange rate changes.

4/ Assumes that PV of private sector debt is equivalent to its face value.

6/ Historical averages and standard deviations are generally derived over the past 10 years, subject to data availability.

7/ Defined as grants, concessional loans, and debt relief.

8/ Grant-equivalent financing includes grants provided directly to the government and through new borrowing (difference between the face value and the PV of new debt) 
Table 1b. Solomon Islands: Sensitivity Analysis for Key Indicators of Public and Publicly Guaranteed External Debt, 2009-29 (In percent)

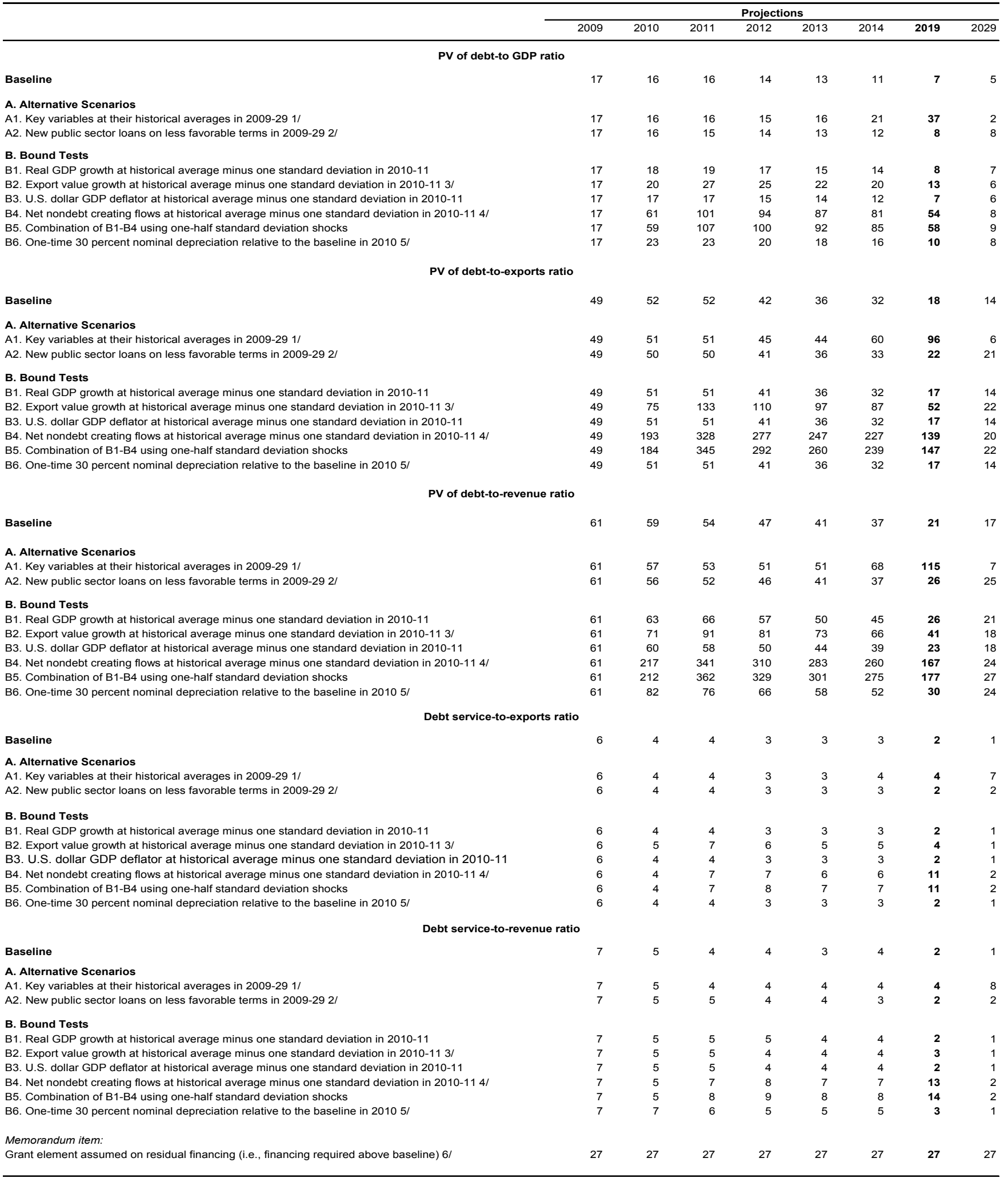

Sources: Solomon Island authorities; and IMF staff estimates and projections.

1/ Variables include real GDP growth, growth of GDP deflator (in U.S. dollar terms), noninterest current account in percent of GDP, and nondebt creating flows.

2/ Assumes that the interest rate on new borrowing is by 2 percentage points higher than in the baseline, while grace and maturity periods are the same as in the baseline.

3/ Exports values are assumed to remain permanently at the lower level, but the current account as a share of GDP is assumed to return to its baseline level after the shock (implicitly assuming an offsetting adjustment in import levels).

$4 /$ Includes official and private transfers and FDI.

5/ Depreciation is defined as percentage decline in dollar/local currency rate, such that it never exceeds 100 percent.

6/ Applies to all stress scenarios except for A2 (less favorable financing) in which the terms on all new financing are as specified in footnote 2. 
Table 2a. Solomon Islands: Public Sector Debt Sustainability Framework, Baseline Scenario, 2006-29

(In percent of GDP, unless otherwise indicated)

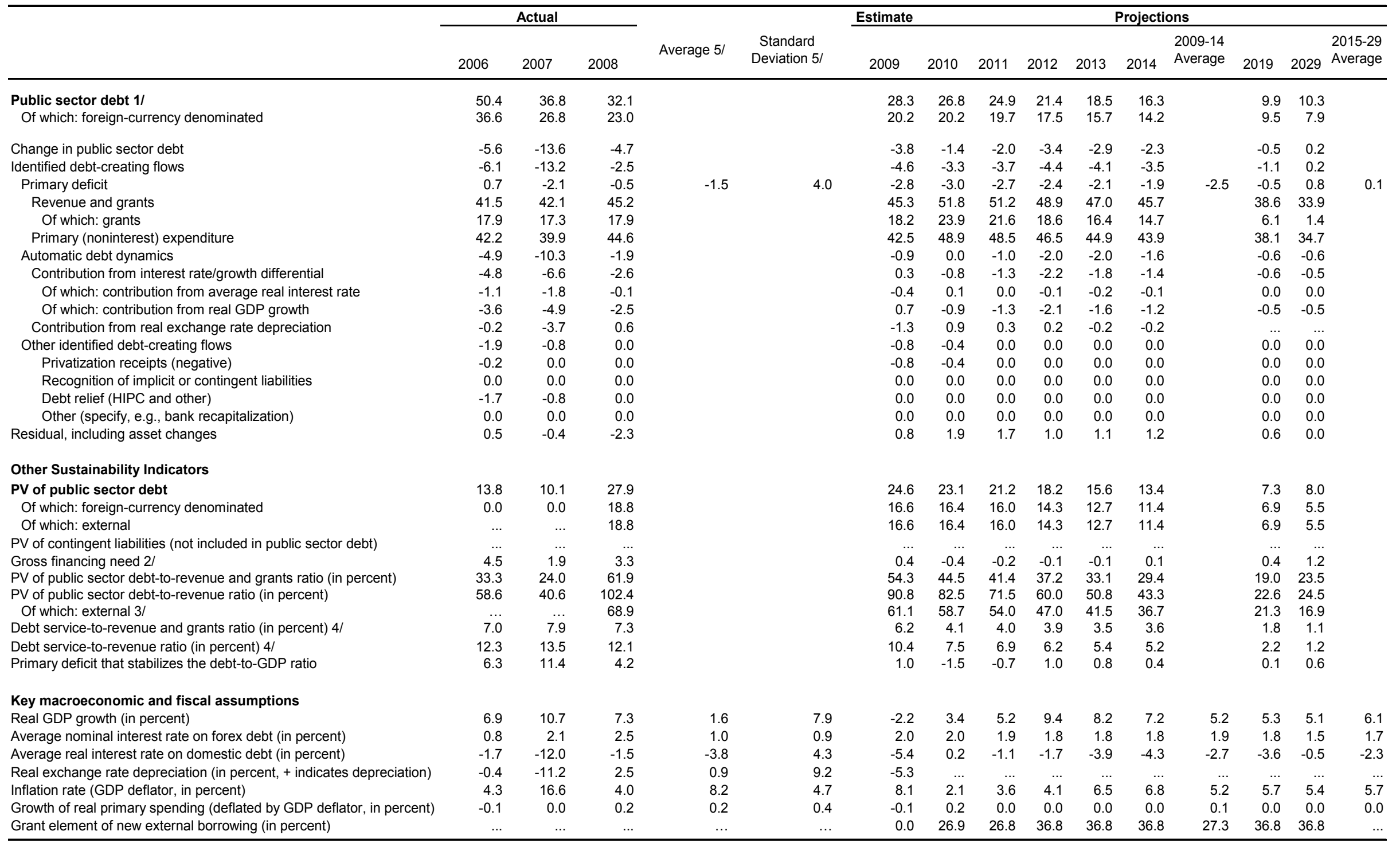

Sources: Solomon Island authorities; and IMF staff estimates and projections.

$1 /$ The public sector covers only the central government.

2/ Gross financing need is defined as the primary deficit plus debt service plus the stock of short-term debt at the end of the last period.

3/ Revenues excluding grants.

4/ Debt service is defined as the sum of interest and amortization of medium and long-term debt.

5/ Historical averages and standard deviations are generally derived over the past 10 years, subject to data availability. 
Table 2b. Solomon Islands: Sensitivity Analysis for Key Indicators of Public Debt 2009-29 (In percent)

Projections

\begin{tabular}{llllllll}
2009 & 2010 & 2011 & 2012 & 2013 & 2014 & 2019 & 2029 \\
\hline
\end{tabular}

PV of Debt-to-GDP Ratio

\section{Baseline}

\section{A. Alternative scenarios}

A1. Real GDP growth and primary balance are at historical averages

A2. Primary balance is unchanged from 2009

A3. Permanently lower GDP growth $1 /$

\section{B. Bound tests}

B1. Real GDP growth is at historical average minus one standard deviations in 2010-11

B2. Primary balance is at historical average minus one standard deviations in 2010-11

B3. Combination of B1-B2 using one half standard deviation shocks

B4. One-time 30 percent real depreciation in 2010

B5. 10 percent of GDP increase in other debt-creating flows in 2010

$\begin{array}{rrrrrrrr}25 & 23 & 21 & 18 & 16 & 13 & 7 & 8 \\ & & & & & & & \\ 25 & 25 & 25 & 25 & 24 & 23 & 18 & -3 \\ 25 & 23 & 21 & 18 & 15 & 11 & -2 & -29 \\ 25 & 24 & 23 & 22 & 21 & 22 & 36 & 122 \\ & & & & & & & \\ & & & & & & & \\ 25 & 28 & 36 & 39 & 42 & 46 & 66 & 117 \\ 25 & 29 & 32 & 28 & 25 & 22 & 14 & 12 \\ 25 & 28 & 32 & 32 & 33 & 34 & 43 & 73 \\ 25 & 31 & 29 & 25 & 22 & 20 & 12 & 11 \\ 25 & 33 & 31 & 28 & 24 & 22 & 13 & 12 \\ & & & & & & & \\ & & & & & & & \\ 54 & 44 & 41 & 37 & 33 & 29 & 19 & 23 \\ & & & & & & & \\ 54 & 48 & 48 & 48 & 48 & 47 & 43 & -8 \\ 54 & 45 & 42 & 36 & 31 & 25 & -6 & -85 \\ 54 & 46 & 45 & 44 & 45 & 46 & 90 & 355 \\ & & & & & & & \\ 54 & 52 & 65 & 74 & 83 & 93 & 164 & 340 \\ 54 & 55 & 62 & 58 & 53 & 49 & 36 & 37 \\ 54 & 53 & 58 & 62 & 66 & 70 & 108 & 212 \\ 54 & 64 & 61 & 56 & 52 & 47 & 35 & 36\end{array}$

\section{Debt Service-to-Revenue Ratio 2/}

\section{Baseline}

\section{A. Alternative scenarios}

A1. Real GDP growth and primary balance are at historical averages

A2. Primary balance is unchanged from 2009

A3. Permanently lower GDP growth $1 /$

\section{B. Bound tests}

B1. Real GDP growth is at historical average minus one standard deviations in 2010-11

B2. Primary balance is at historical average minus one standard deviations in 2010-11

B3. Combination of B1-B2 using one half standard deviation shocks

B4. One-time 30 percent real depreciation in 2010

B5. 10 percent of GDP increase in other debt-creating flows in 2010

\section{PV of Debt-to-Revenue Ratio 2/}

Sources: Solomon Island authorities; and IMF staff estimates and projections.

1/ Assumes that real GDP growth is at baseline minus one standard deviation divided by the square root of the length of the projection period.

2/ Revenues are defined inclusive of grants. 
Table 3a. Solomon Islands: External Debt Sustainability Framework, Alternative Scenario, 2006-29 1/

(In percent of GDP, unless otherwise indicated)

\begin{tabular}{|c|c|c|c|c|c|c|c|c|c|c|c|c|c|c|c|}
\hline & \multicolumn{3}{|c|}{ Actual } & \multirow{2}{*}{$\begin{array}{l}\text { Historical } 6 / \\
\text { Average }\end{array}$} & \multirow{2}{*}{$\begin{array}{l}\text { Standard 6/ } \\
\text { Deviation }\end{array}$} & \multicolumn{6}{|c|}{ Projections } & \multirow[b]{2}{*}{$\begin{array}{l}2009-14 \\
\text { Average }\end{array}$} & \multirow[b]{2}{*}{2019} & \multirow[b]{2}{*}{2029} & \multirow[b]{2}{*}{$\begin{array}{l}2015-29 \\
\text { Average }\end{array}$} \\
\hline & 2006 & 2007 & 2008 & & & 2009 & 2010 & 2011 & 2012 & 2013 & 2014 & & & & \\
\hline External debt (nominal) $1 /$ & 42.0 & 30.9 & 26.6 & & & 23.6 & 23.4 & 22.7 & 21.0 & 19.1 & 16.3 & & 10.9 & 9.7 & \\
\hline Of which: public and publicly guaranteed (PPG) & 36.6 & 26.8 & 23.0 & & & 20.2 & 20.2 & 19.7 & 18.2 & 16.6 & 14.2 & & 9.5 & 8.4 & \\
\hline Change in external debt & -2.8 & -11.1 & -4.3 & & & -2.9 & -0.2 & -0.7 & -1.7 & -1.9 & -2.8 & & -0.6 & 0.1 & \\
\hline Identified net debt-creating flows & -8.4 & -10.8 & 0.3 & & & 2.6 & -1.4 & -1.8 & 2.6 & 5.9 & -7.1 & & 0.3 & 0.6 & \\
\hline Noninterest current account deficit & 1.1 & 7.4 & 15.6 & 2.4 & 9.7 & 20.5 & 29.5 & 27.0 & 27.9 & 29.4 & 40.8 & & 7.6 & 2.5 & 12.0 \\
\hline Deficit in balance of goods and services & 17.4 & 19.7 & 20.5 & & & 13.4 & 30.7 & 28.3 & 29.7 & 32.6 & 43.2 & & 8.1 & 6.5 & \\
\hline Exports & 35.5 & 36.7 & 37.3 & & & 33.5 & 31.3 & 30.8 & 29.2 & 26.6 & 30.4 & & 33.9 & 21.3 & \\
\hline Imports & 52.9 & 56.4 & 57.8 & & & 46.9 & 62.0 & 59.1 & 58.9 & 59.2 & 73.6 & & 42.0 & 27.8 & \\
\hline Net current transfers (negative = inflow) & -19.0 & -17.8 & -18.6 & -6.8 & 8.8 & -19.2 & -25.1 & -22.9 & -21.0 & -19.5 & -17.3 & & -9.2 & -5.5 & -8.5 \\
\hline Of which: official & -15.4 & -15.7 & -18.0 & & & -16.7 & -22.7 & -20.4 & -18.5 & -17.1 & -14.8 & & -6.6 & -2.4 & \\
\hline Other current account flows (negative $=$ net inflow) & 2.7 & 5.4 & 13.8 & & & 26.3 & 24.0 & 21.7 & 19.2 & 16.3 & 14.9 & & 8.7 & 1.6 & \\
\hline Net FDI (negative $=$ inflow) & -5.8 & -9.7 & -13.3 & -2.6 & 5.6 & -19.1 & -30.7 & -28.2 & -24.8 & -23.1 & -46.4 & & -6.7 & -2.0 & -12.4 \\
\hline Endogenous debt dynamics 2 I & -3.7 & -8.5 & -2.1 & & & 1.2 & -0.2 & -0.7 & -0.4 & -0.4 & -1.4 & & -0.5 & 0.0 & \\
\hline Contribution from nominal interest rate & 0.5 & 0.8 & 0.8 & & & 0.6 & 0.6 & 0.5 & 0.5 & 0.4 & 0.4 & & 0.2 & 0.2 & \\
\hline Contribution from real GDP growth & -2.8 & -3.5 & -2.0 & & & 0.6 & -0.8 & -1.2 & -0.9 & -0.8 & -1.8 & & -0.8 & -0.2 & \\
\hline Contribution from price and exchange rate changes & -1.4 & -5.8 & -0.8 & & & & & & & & & & & & \\
\hline Residual (3-4) 3/ & 5.6 & -0.3 & -4.6 & & & -5.5 & 1.2 & 1.1 & -4.3 & -7.8 & 4.3 & & -0.9 & -0.5 & \\
\hline Of which: exceptional financing & 0.0 & 0.0 & 0.0 & & & 0.0 & 0.0 & 0.0 & 0.0 & 0.0 & 0.0 & & 0.0 & 0.0 & \\
\hline PV of external debt $4 /$ & & & 22.4 & & & 19.9 & 19.6 & 19.0 & 17.6 & 16.0 & 13.6 & & 8.4 & 7.1 & \\
\hline In percent of exports & $\ldots$ & $\ldots$ & 60.1 & & & 59.5 & 62.5 & 61.6 & 60.3 & 60.2 & 44.7 & & 24.7 & 33.5 & \\
\hline PV of PPG external debt & $\ldots$ & $\ldots$ & 18.8 & & & 16.6 & 16.4 & 16.0 & 14.8 & 13.5 & 11.4 & & 6.9 & 5.8 & \\
\hline In percent of exports & $\ldots$ & $\ldots$ & 50.4 & & & 49.4 & 52.2 & 51.8 & 50.7 & 50.6 & 37.6 & & 20.3 & 27.3 & \\
\hline In percent of government revenues & $\ldots$ & $\ldots$ & 68.9 & & & 61.1 & 58.6 & 53.9 & 48.7 & 43.9 & 36.9 & & 21.6 & 19.7 & \\
\hline Debt service-to-exports ratio (in percent) & 3.5 & 6.7 & 6.8 & & & 6.9 & 5.0 & 5.0 & 4.8 & 4.9 & 4.4 & & 2.3 & 2.1 & \\
\hline PPG debt service-to-exports ratio (in percent) & 2.5 & 5.8 & 5.9 & & & 6.0 & 4.3 & 4.2 & 4.1 & 4.2 & 3.8 & & 1.9 & 1.5 & \\
\hline PPG debt service-to-revenue ratio (in percent) & 3.8 & 8.6 & 8.1 & & & 7.4 & 4.8 & 4.4 & 3.9 & 3.6 & 3.8 & & 2.1 & 1.1 & \\
\hline Total gross financing need (Billions of U.S. dollars) & 0.0 & 0.0 & 0.0 & & & 0.0 & 0.0 & 0.0 & 0.0 & 0.1 & 0.0 & & 0.0 & 0.0 & \\
\hline Noninterest current account deficit that stabilizes debt ratio & 3.9 & 18.5 & 20.0 & & & 23.4 & 29.7 & 27.8 & 29.6 & 31.3 & 43.6 & & 8.2 & 2.5 & \\
\hline \multicolumn{16}{|l|}{ Key macroeconomic assumptions } \\
\hline Real GDP growth (in percent) & 6.9 & 10.7 & 7.3 & 1.6 & 7.9 & -2.2 & 3.4 & 5.2 & 4.1 & 4.1 & 10.9 & 4.3 & 7.4 & 2.0 & 4.9 \\
\hline GDP deflator in U.S. dollar terms (change in percent) & 3.2 & 15.9 & 2.7 & 3.4 & 8.4 & 4.0 & -0.8 & -0.8 & 0.8 & 3.3 & 3.7 & 1.7 & 2.6 & 2.4 & 2.7 \\
\hline Effective interest rate (percent) $5 /$ & 1.4 & 2.4 & 2.8 & 2.1 & 1.2 & 2.4 & 2.4 & 2.3 & 2.2 & 2.2 & 2.2 & 2.3 & 2.2 & 2.0 & 2.1 \\
\hline Growth of exports of G\&S (U.S. dollar terms, in percent) & 16.9 & 32.5 & 12.0 & 5.9 & 25.4 & -8.5 & -4.2 & 2.6 & -0.6 & -1.8 & 31.4 & 3.1 & 13.5 & -6.9 & 5.4 \\
\hline Growth of imports of G\&S (U.S. dollar terms, in percent) & 39.4 & 36.8 & 12.9 & 10.4 & 30.2 & -17.3 & 35.5 & -0.6 & 4.6 & 8.2 & 43.0 & 12.2 & 0.9 & 3.0 & 1.2 \\
\hline Grant element of new public sector borrowing (in percent) & & & & $\ldots$ & $\ldots$ & 0.0 & 25.1 & 25.1 & 36.8 & 36.8 & 36.8 & 26.8 & 36.8 & 36.8 & 36.8 \\
\hline Government revenues (excluding grants, in percent of GDP) & 23.6 & 24.8 & 27.3 & & & 27.1 & 27.9 & 29.6 & 30.4 & 30.7 & 31.0 & & 31.8 & 29.6 & 30.9 \\
\hline Aid flows (in Billions of U.S. dollars) 7/ & 0.1 & 0.1 & 0.1 & & & 0.1 & 0.2 & 0.2 & 0.1 & 0.1 & 0.1 & & 0.1 & 0.0 & \\
\hline Of which: Grants & 0.1 & 0.1 & 0.1 & & & 0.1 & 0.2 & 0.2 & 0.1 & 0.1 & 0.1 & & 0.1 & 0.0 & \\
\hline Of which: concessional loans & 0.0 & 0.0 & 0.0 & & & 0.0 & 0.0 & 0.0 & 0.0 & 0.0 & 0.0 & & 0.0 & 0.0 & \\
\hline Grant-equivalent financing (in percent of GDP) $8 /$ & $\ldots$ & $\ldots$ & $\ldots$ & & & 18.2 & 24.3 & 21.9 & 19.6 & 18.0 & 15.7 & & 6.7 & 2.0 & 5.7 \\
\hline Grant-equivalent financing (in percent of external financing) 8/ & & & $\ldots$ & & & 100.0 & 95.8 & 95.5 & 99.0 & 98.3 & 97.3 & & 92.2 & 83.2 & 90.1 \\
\hline \multicolumn{16}{|l|}{ Memorandum items: } \\
\hline Nominal GDP (Billions of U.S. dollars) & 0.5 & 0.6 & 0.6 & & & 0.7 & 0.7 & 0.7 & 0.7 & 0.8 & 0.9 & & 1.5 & 2.8 & \\
\hline Nominal dollar GDP growth & 10.3 & 28.3 & 10.2 & & & 1.8 & 2.5 & 4.4 & 4.9 & 7.6 & 15.1 & 6.0 & 10.2 & 4.4 & 7.7 \\
\hline PV of PPG external debt (in Billions of US dollars) & 0.0 & $\ldots$ & 0.1 & & & 0.1 & 0.1 & 0.1 & 0.1 & 0.1 & 0.1 & & 0.1 & 0.2 & \\
\hline (PVt-PVt-1)/GDPt-1 (in percent) & $\ldots$ & . & & & & -1.4 & -0.1 & 0.3 & -0.4 & -0.3 & -0.3 & -0.4 & 0.2 & 0.3 & 0.2 \\
\hline
\end{tabular}

Sources: Solomon Authorities; and IMF staff estimates and projections.

$1 /$ Includes both public and private sector external debt.

$2 /$ Derived as $[r-g-\rho(1+g)] /(1+g+\rho+g \rho)$ times previous period debt ratio, with $r=$ nominal interest rate; $g=$ real GDP growth rate, and $\rho=$ growth rate of GDP deflator in U.S. dollar terms.

3 / Includes exceptional financing (i.e., changes in arrears and debt relief); changes in gross foreign assets; and valuation adjustments. For projections also includes contribution from price and exchange rate changes.

4/ Assumes that PV of private sector debt is equivalent to its face value.

6/ Historical averages and standard deviations are generally derived over the past 10 years, subject to data availability.

7/ Defined as grants, concessional loans, and debt relief.

8/ Grant-equivalent financing includes grants provided directly to the government and through new borrowing (difference between the face value and the PV of new debt). 
Table 3b.Solomon Islands: Public Sector Debt Sustainability Framework, Alternative Scenario, 2006-29 (In percent of GDP, unless otherwise indicated)

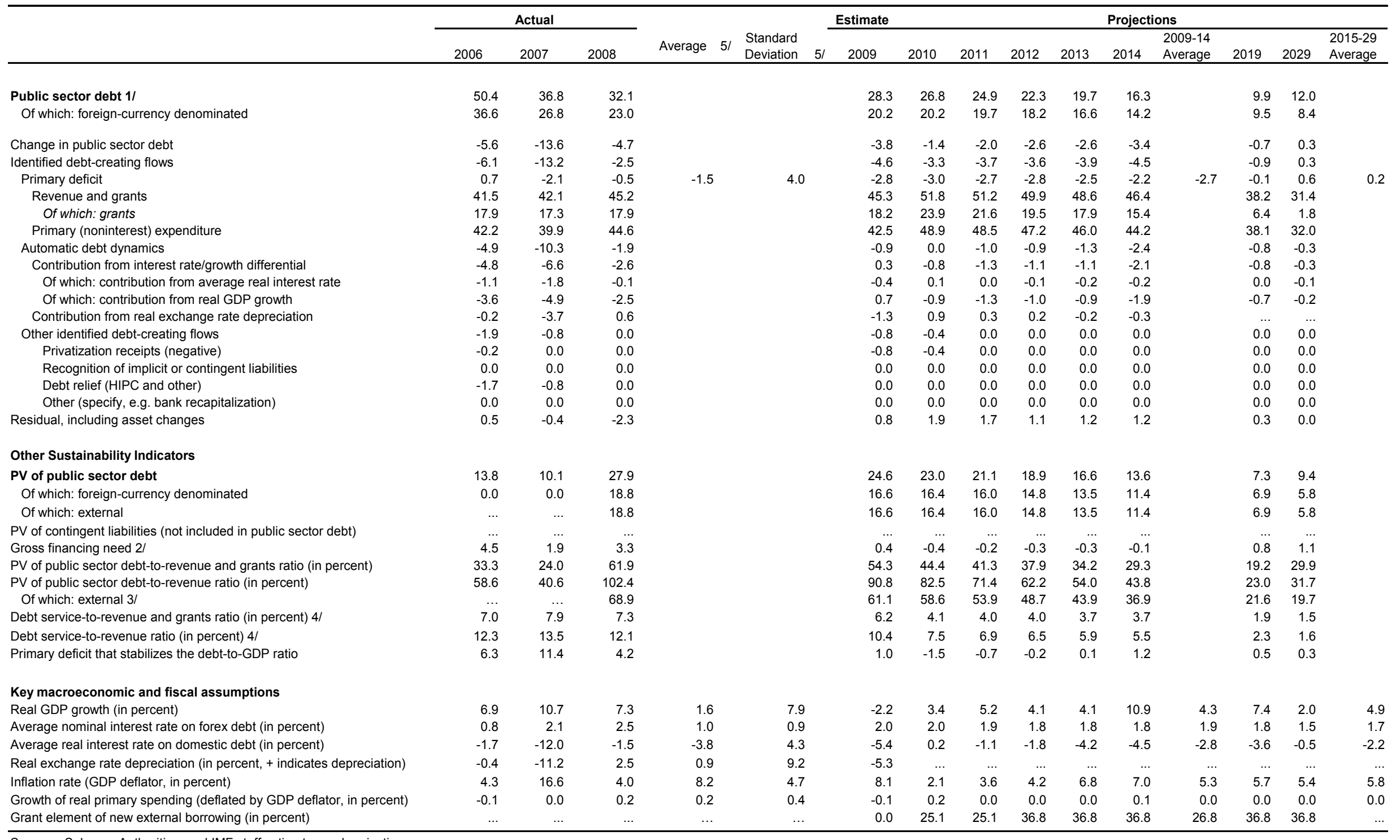

Sources: Solomon Authorities; and IMF staff estimates and projections.

$1 /$ The public sector covers only the central government.

2/ Gross financing need is defined as the primary deficit plus debt service plus the stock of short-term debt at the end of the last period.

3/ Revenues excluding grants.

4/ Debt service is defined as the sum of interest and amortization of medium- and long-term debt.

5/ Historical averages and standard deviations are generally derived over the past 10 years, subject to data availability. 
Press Release No. 10/223

International Monetary Fund

FOR IMMEDIATE RELEASE

Washington, D.C. 20431 USA

June 2, 2010

\section{IMF Executive Board Approves US\$18.3 Million Standby Credit Facility Arrangement for the Solomon Islands}

The Executive Board of the International Monetary Fund (IMF) today approved an 18-month SDR 12.48 million (about US\$18.3 million) arrangement under the Standby Credit Facility for the Solomon Islands in support of the authorities' economic reform program. An amount equivalent to SDR 3.12 million (about US\$4.6 million) is immediately available to the Solomon Islands.

The total amount of IMF resources made available under the arrangement equals 120 percent of the country's quota of SDR10.4 million.

In view of the adverse impact of the global economic downturn, the key objective of the authorities' economic reform program is to establish a basis for resuming solid growth and reducing external vulnerability in a low-inflation environment, while advancing poverty alleviation efforts. To this end, the program seeks to strengthen the fiscal position, enhance monetary policy operations, and safeguard the domestic financial sector. By laying a strong macroeconomic foundation, the program is also expected to help catalyze additional donor support for the country.

Following the Executive Board's discussion on the Solomon Islands, Mr. Naoyuki Shinohara, Deputy Managing Director and Acting Chair, stated:

"Following the global recession and the continued decline in logging output, the Solomon Islands has experienced an economic downturn, pressures on the government's cash reserves, and increased macroeconomic vulnerabilities. The authorities' program, supported by a Standby Credit Facility arrangement, aims to restore macroeconomic stability, reduce destabilizing imbalances, and close the financing gaps, including by catalyzing donor support. Strong ownership and steadfast implementation of the program will be important.

"Key macroeconomic reforms and stabilization measures under the program would allow solid growth to resume in a low inflation environment, thereby advancing poverty alleviation 
efforts. The core elements of the program are to strengthen government finances, improve monetary operations, safeguard international reserves, and contain financial sector risks.

"Fiscal discipline will continue to serve as the main anchor for macroeconomic stability. Efforts will focus on rebuilding cash reserves mainly by strengthening revenue collection and prioritizing expenditure. Adopting a fiscal responsibility law and devising a proper resource tax regime would help enhance budget discipline, improve revenue transparency, and ensure a sustainable fiscal path.

"The current monetary stance is broadly appropriate, and sufficiently accommodative to support economic recovery. The program seeks to strengthen the operational framework of monetary policy and introduce new policy instruments to help banks manage liquidity, ensuring long-term price stability.

"New prudential regulations have been introduced recently to mitigate risks facing the banking sector resulting from the economic downturn. Timely and consistent enforcement of these new regulations will be critical to financial stability. The authorities are committed to strengthening the oversight and independence of the National Provident Fund to safeguard its long-term financial viability."

\section{Recent Economic Developments}

ANNEX

The Solomon Islands has been affected since late 2008 by the adverse impact of the global economic crisis and a sharp decline in logging output. The authorities' estimate shows the economy contracted by $2 \frac{1}{4}$ percent in 2009 , compared with an expansion of $7 \frac{1}{4}$ percent in 2008. The fall in activity was mainly due to declining production of fish and timber and weak commodity prices and output, which fed into domestic demand. Inflation pressures, meanwhile, eased mostly due to falling fuel and food prices, but also due to weak demand conditions. With sluggish domestic demand, bank credit also contracted. Reflecting a weak external environment, the current account deficit widened to 21 percent of GDP in 2009. Increases in mining-related foreign direct investment (FDI), reinvested earnings, and other inflows, including the SDR allocations, however, helped official foreign reserves rise to US\$146 million at end-2009 (about 41/4 months of next year's projected imports of goods and nonfactor services).

The near-term macroeconomic outlook is expected to remain challenging. Growth is projected to rebound to around $3 \frac{1}{2}$ percent in 2010 on a global recovery in commodity demand and prices and new investment and capacity improvements in mining, telecommunications, and fisheries. However, further declines in logging production will continue to act as a drag on economic activity. With little capacity to borrow at home or 
abroad, the country faces pressing needs to better safeguard its economy against vulnerability.

\section{Program Summary}

Against this background, the authorities have embarked on a program of economic reform to make the economy less susceptible to adverse shocks and strengthen its macroeconomic base. They have requested IMF financial assistance to support their efforts.

The authorities' program includes the following key elements:

- Strengthening fiscal operations: To bolster the fiscal position and improve budget discipline, the program includes policy measures to build cash reserves, principally by strengthening revenue administration, including in the resource sector, and better prioritizing expenditures. These measures also aim at creating additional fiscal space to meet social and development needs. To improve budget discipline, the authorities envisage establishing a stronger budgetary and institutional framework by adopting a fiscal responsibility law that would better ensure sound fiscal management.

- Improving monetary operations: While the current monetary stance is broadly appropriate, with monetary targets sufficiently accommodative, the program envisions further steps to strengthen the operational framework and introduce new instruments for conducting monetary policy. In light of the vulnerability to shocks, the authorities intend to take necessary measures to maintain an adequate level of foreign reserves.

- Safeguarding the financial sector: The program envisions maintaining a sound financial system by tightly enforcing new prudential regulations. The authorities also intend to strengthen the oversight and independence of the National Provident Fund to ensure its long term financial viability.

The Solomon Islands became of member of the IMF on September 22, 1978.

For additional background on the IMF and the Solomon Islands, see: http://www.imf.org/external/country/SLB/index.htm 
Solomon Islands: Selected Economic Indicators, 2007-11

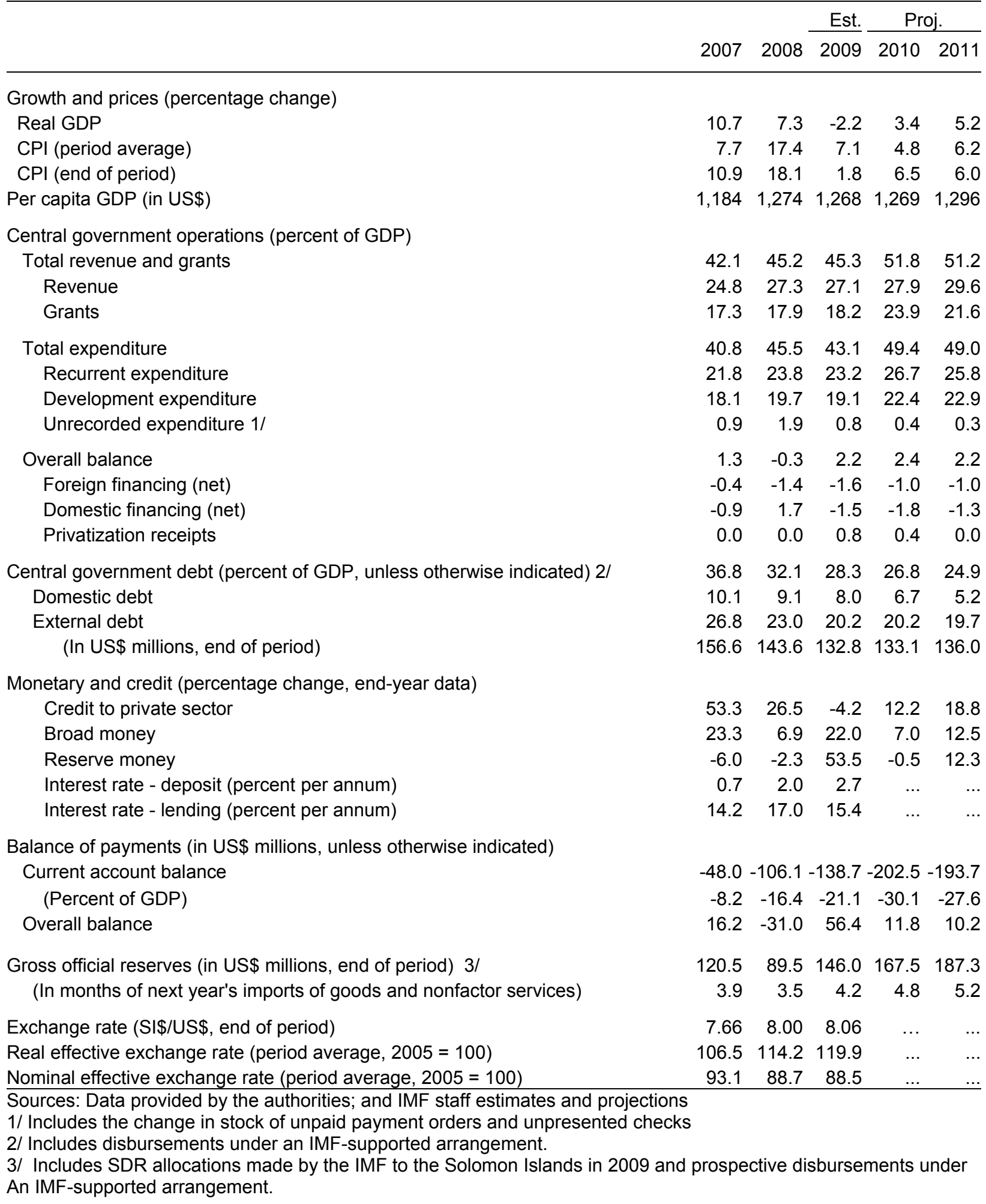




\section{Statement by Christopher Y. Legg, Alternate Executive Director for Solomon Islands and Mario G. Di Maio, Advisor to the Executive Director June 2, 2010}

To safeguard macroeconomic stability in the face of external shocks my Solomon Islands authorities have developed a program of economic adjustment. They request IMF support for their adjustment program, in the form of an 18-month Standby Credit Facility for SDR 12.48 million (120 per cent of quota). International agencies and bilateral donors are also providing assistance in support of the adjustment goals. This program represents a committed effort to sustain hard won gains in macroeconomic policy following political and economic instability at the start of this decade, and helps lay the foundations for a recovery in private sector activity.

\section{Background}

The rebound in growth in the middle of the decade was the result of a return to stability after an extended period of political, social and economic disruption. With strong support from development partners, economic policy returned to focusing on bringing inflation under control, reining in the budget deficit, restructuring public debt, and addressing structural challenges to improve the climate for private sector growth. However, the challenges remain large - real economic output only returned to 1999 levels in 2007 and development and infrastructure needs remain substantial.

Output fell by 2.2 percent in 2009 as external developments reduced export demand and prices for Solomon Islands main export commodities - logs, fish and agriculture. The situation was exacerbated by a long anticipated structural decline in log volumes and lower prices. In 2008, logging revenue comprised 60 percent of export income, and it is also a substantial source of government revenue and local cash income for rural communities. The external accounts came under pressure during mid-2009 with reserves declining below 3 months before picking up towards the end of 2009 to just over four months of import cover.

The authorities' policy space to address these external shocks was severely limited. Fiscal policy was constrained by restrictions on public borrowing, as a condition of debt restructuring. Spending was reduced by 10 percent from the 2009 budget and additional public sector hiring was suspended. Excise taxes were raised during mid-2009 to deal with anticipated revenue shortfalls. Capacity constraints limited implementation of spending plans, and together with challenges in public financial management, resulted in a fiscal surplus of more than 2.2 percent of GDP in 2009. Despite this relatively robust end-of-year position, cash constraints during the year necessitated tight control of day-to-day spending commitments and an increase in payment delays to domestic suppliers. Although monetary policy was eased, the uncertain economic and external environment meant that these changes had a limited impact on demand.

\section{Program objectives and design}

Despite better prospects for world growth in 2010, the authorities face immediate challenges in the form of a still fragile recovery, continued external vulnerabilities, and a challenging 
fiscal outlook that requires a concerted policy response. Their response is supported by the Fund and development partners. To safeguard external stability the central objectives of the program are: (i) to put government finances back on track by addressing immediate cash pressures through spending restraint and buttressing revenue, while using external support to build a larger cash buffer to manage cash flows and provide a buffer for future shocks; (ii) contain inflation risks by improving the effectiveness of monetary policy operations; and (iii) avert potential future financial sector risks. The program incorporates the core elements that the Board considered central to macroeconomic stability during the 2009 Article IV.

The fiscal program targets an overall balance of 2.4 percent of GDP, with substantial budget support from the European Union helping support the build-up of cash balances to 2 months of recurrent spending. The fiscal program envisages immediate adjustment to bring spending plans back into line with revenue in 2010 and to continue the disciplined approach to the public wage bill. Social spending increases in health and education are being preserved, while the fiscal surplus provides for continued repayment of debt obligations. On the revenue side, the program's aims are supported through changes to strengthen customs collection - including increasing the effective rate of customs duty. The program will also resolve the long-standing issue of adequate taxation of logging exports by introducing a process that depoliticizes adjustment to the valuation of logs used in calculating the tax due. The authorities consider that, given the low effective customs duty rate, there are significant gains likely from recently introduced administrative measures to improve enforcement. They have been appropriately cautious in building the anticipated revenue gains from these measures into the fiscal program.

The authorities also recognize that in addition to immediate spending and tax changes, more-fundamental reform is needed. To avoid a repeat of mistakes in the logging sector, the authorities are committed to developing a robust tax regime on natural resources for pending gold and nickel projects. Further, the development of a fiscal responsibility law would provide for a more medium-term orientation to tax and spending, which will be supported by a public expenditure review undertaken in conjunction with the World Bank to improve the effectiveness of public spending.

Sound monetary and exchange rate policy has been a hallmark of Solomon Islands macroeconomic management. With the outlook for inflation subdued, the authorities do not face immediate pressure to tighten, though they remain ready to tighten policy earlier if it proves necessary to control inflation and safeguard international reserves. Foreign reserves recovered somewhat towards the end of 2009, partly due to several one-off factors. With fiscal restraint and additional support from development partners the program provides a comfortable cushion of external reserves. To be well-positioned to manage the large liquidity overhang, the Central Bank of the Solomon Islands (CBSI) will introduce an overnight facility and prepare for the issuance of short-term bank bills to manage the money supply.

Recognizing the risks associated with the strong private sector credit growth in the period leading up to the recent slowdown, the authorities began to tighten up financial regulation and supervision. As a backstop, and to buttress assurances of support from external parent banks, the authorities will issue regulations strengthening the role of the CBSI as a lender of last resort. Banks are strongly capitalized and have large and robust external shareholders. However, there are potential risks in the medium-term around the National Provident Fund 
(NPF), which is the largest financial institution in the Solomon Islands, stemming from uncertainty about its objectives and a lack of adequate supervision. Addressing these risks and ensuring soundness of the NPF requires institutional changes to clarify the CBSI's responsibility for regulation and clarify that the main objective of the Fund - providing sustainable retirement savings - is not subordinated to other government goals.

\section{Medium-term prospects and risks}

The medium-term economic prospects for the Solomon Islands are reasonably good. The maintenance of macroeconomic stability and further progress on structural reform will support increased investment, including in natural resources where several large projects will make a substantial contribution to output. The authorities' acknowledge that further progress on the agenda of structural reform is needed to strengthen medium-term growth prospects. They intend to build on the steps taken to commercialize operations in stateowned enterprises; improve competitiveness, including the deregulation of telecommunications; and reduce the cost of doing business through revision of the legal framework.

We recognize that the program is not without risks and the design of the program seeks to mitigate those. First, the political situation beyond the election due at the beginning of August 2010 and the likely makeup and policy program of the new government is not yet clear. However, the current government is committed to the program, as indicated by the implementation of significant spending, and tax actions in the lead-up to the elections. And while the execution of the 2009 budget was not ideal, the authorities took difficult decisions that ensured a broadly balanced budget. The second key risk relates to the capacity constraints in implementing the program. There is critical support being provided in the form of technical assistance from Fund, particularly on the strengthening of monetary and prudential management, development of resource revenue regime, and support to the public spending review. Our view is that these risks are manageable but they cannot be eliminated and are not unusual compared with other programs the Fund has supported. There remains a strong commitment across the political spectrum to social and economic stability to underpin the continued rebuilding of the Solomon Islands. Further, the Program is consistent with the economic and public financial management objectives of the Core Economic Working Group which brings together political leaders and development partners to discuss economic strategy.

My authorities would like to extend their appreciation to Fund management and other development partners for their support of the Solomon Islands policy response to these challenging economic circumstances. They appreciate the dedicated and professional approach from the Fund staff and look forward to maintaining a strong relationship during the period of the program and beyond. 